
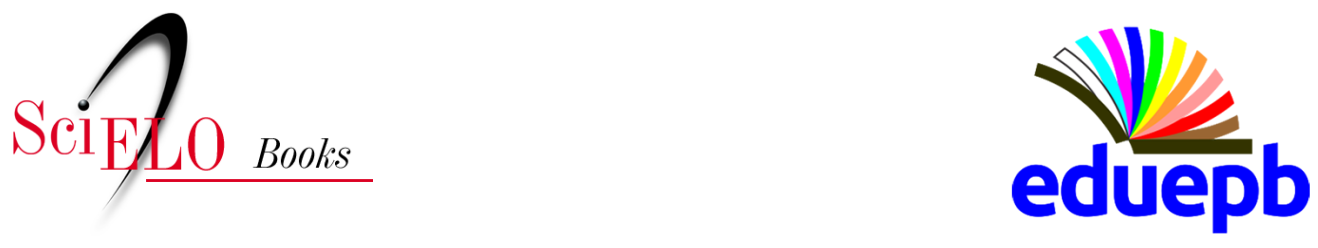

\title{
A EAD Como Prática Político-Social e Discursiva
}

\author{
Antonio Roberto Faustino da Costa
}

\section{SciELO Books / SciELO Livros / SciELO Libros}

COSTA, A. R. F. A EAD Como Prática Político-Social e Discursiva. In: Industrialização do ensino e política de educação a distância [online]. Campina Grande: EDUEPB, 2019, pp. 153-313. Ensino e aprendizagem collection, vol. 4. ISBN: 978-85-7879-350-0.

https://doi.org/10.7476/9788578793500.0005.

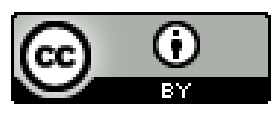

All the contents of this work, except where otherwise noted, is licensed under a Creative Commons Attribution 4.0 International license.

Todo o conteúdo deste trabalho, exceto quando houver ressalva, é publicado sob a licença Creative Commons Atribição 4.0.

Todo el contenido de esta obra, excepto donde se indique lo contrario, está bajo licencia de la licencia Creative Commons Reconocimento 4.0. 


\title{
A EAD COMO PRÁTICA POLÍTICO-SOCIAL E DISCURSIVA
}

\begin{abstract}
Ao tomarmos o discurso como efeito de sentidos entre interlocutores, englobando os enunciados produzidos por eles no processo de enunciação, consideramos a princípio que o discurso em torno da política nacional de educação a distância é regulado por uma exterioridade sócio-histórica e ideológica que é determinante às regularidades lingüísticas, seu uso e sua função junto àquele discurso. O que implica inscrevermos o enunciado numa formação discursiva determinada, sobretudo considerando que tendem a habitar o nosso corpus de análise sujeitos e posições institucionais, políticas e ideológicas bem definidas, emanadas de um Estado de orientação capitalista, ao qual não se apresenta nada contraditório transformar um discurso em instrumento estratégico ao processo de institucionalização da industrialização do ensino no país.

Nesse sentido, não pretendemos adotar em nossa análise uma ou outra tendência tradicional dos estudos da linguagem: nem o método histórico-comparado que prevalece no século XIX, considerando a linguagem como "produto da história"; nem o estruturalismo do século XX que define a linguagem como uma estrutura (ORLANDI, 1993a, p.16). Além disso, seguindo Foucault (2001b, 2002,
\end{abstract}


2004), nosso estudo distancia-se dos cânones da história convencional, de "fazer a história" da educação a distância ou da política de EAD no Brasil contemporâneo, objetivando em contrapartida reconhecer a lógica que rege a ordem do discurso em torno de tal política. O fato de concebermos esse discurso como uma seqüência ou "série de acontecimentos" reporta-nos, no entanto, ao âmbito da história (FOUCAULT, 2001a, p.258).

Ao invés de partir da história para o texto, como se predominasse uma relação de causa e efeito, tomamos o textual enquanto materialidade histórica que comporta sua própria temporalidade e historicidade, ainda que relacionada à realidade sócio-histórica. Se em algum momento, porém, for necessário fazer uma história dos objetos discursivos, não importará tanto remeter a sua origem, mas percorrer o nexo das suas regularidades. Será preciso compreender o discurso, conforme Foucault (2002, p.28), mediante a emergência dos acontecimentos discursivos, na sua pontualidade ou dispersão temporal que o torna capaz de ser transformado, esquecido ou repetido. Mesmo como estrutura, a regularidade não impede a "força de organização do sentido", própria aos acontecimentos discursivos que, de modo geral, apresentam-se únicos (MAZIÈRE, 2007, p.30).

Levando essa premissa às últimas consequências, o discurso da industrialização do ensino assume uma regularidade tal na contemporaneidade que parece investir, como diria Foucault (2004, p.17), atributos de uma vontade de verdade que não só profetiza o futuro da educação, mas contribui para sua realização, exercendo tanto pressão quanto poder de coerção sobre os demais discursos. Apoiada em um suporte institucional, como os outros sistemas de exclusão, essa vontade de verdade mobiliza 
um conjunto de práticas sociais, incluindo a pedagogia, sendo ainda mais decisivamente reconduzida pelo modo como o saber é valorizado, distribuído e aplicado em meio à sociedade.

Ressalta Pêcheux (1988, p.145) que exercem papel decisivo nesse sentido - seja em meio ao suporte institucional seja em meio ao tecido social - os aparelhos ideológicos de Estado, constituídos em lugar e meio de materialização privilegiados dessa vontade de verdade ou, de forma mais abrangente, da ideologia dominante. "É pelo estabelecimento dos AIE, aonde esta ideologia é realizada e se realiza, que ela se torna dominante." (ALTHUSSER, 1992, p.106) Em outras palavras, a ideologia dominante pressupõe uma formação discursiva, cuja dinâmica é acionada por intermédio de uma prática discursiva.

Considerando o discurso como uma prática por excelência, Foucault (2002, p.51) nos adverte que cabe ao analista do discurso desvelar a complexidade e densidade das práticas discursivas, evidenciando que uma mudança na ordem do discurso supõe, acima de tudo, transformações na própria ação social, o que "consiste em não aceitar nenhum discurso fora do sistema de relações materiais que o estruturam e o constituem". A marca da AD, por assim dizer, é a reflexão sobre a linguagem enquanto prática.

$\mathrm{Na}$ realidade, o discurso representa não apenas um conjunto de textos, mas uma prática em meio às "práticas que constituem a sociedade na história, com a diferença de que a prática discursiva se especifica por ser uma prática simbólica." (ORLANDI, 2002, p.71) Ainda assim, a prática de produção do discurso não constitui exceção alguma no conjunto das diversas práticas, posto que, igualmente a essas, funciona como interpelação (PÊCHEUX, 
1988, p.267), através da qual os aparelhos ideológicos de Estado interpelam os indivíduos em (seus) sujeitos (ALTHUSSER, 1992). Para vislumbrar a regularidade do discurso enquanto prática, devemos então analisar não os seus produtos mas, principalmente, os processos de sua produção. Estudar o seu funcionamento ideológico pressupõe reconstituí-la como prática entre as demais, sobretudo, objetivando descrever como se formam seus objetos e suas modalidades de enunciação, conceitos e escolhas teóricas (FOUCAULT, 2002, p.211).

A categoria prática discursiva proposta por Foucault indica uma "inovação teórica, no fundo materialista" (LECOURT, 1971, p.51), que amplia a noção bakhtiniana de que a palavra enquanto signo social investiria o fenômeno ideológico, demandando uma análise capaz de descrever o seu funcionamento como instrumento da consciência e elemento fundamental a toda ideologia. Conforme já nos alertava Bakhtin (1988, p.32), como o domínio dos signos coincide com o domínio do ideológico, pois não há ideologia sem signo e tudo que é ideológico assume valor simbólico, as formas do signo são determinadas não só pela organização social dos indivíduos, como também pelas condições em que a sua interação acontece: "Uma modificação destas formas ocasiona uma modificação do signo."

A política nacional de educação a distância, sob esse prisma, constitui não apenas uma prática política ou social, como também - e ao mesmo tempo - uma prática discursiva. "A política é um campo de batalha em que se trava uma guerra simbólica para estabelecer relações de dominação ou pactos de convenção." (CHARAUDEAU, 2006, p.46) Segundo Maingueneau (1997, p.82), a categoria prática discursiva é muitas vezes adotada como uma variante de FD para designar que o discurso representa 
uma modalidade de ação social, seja numa perspectiva pragmática seja numa perspectiva marxista que o concebe como práxis. O melhor exemplo disso seria a seguinte definição de Foucault (2002, p.136): "um conjunto de regras anônimas, históricas, sempre determinadas no tempo e no espaço, que definiram, em uma dada época e para uma determinada área social, econômica, geográfica ou lingüística, as condições de exercício da função enunciativa."

Assim como as práticas não discursivas, o discurso também adquire importância de sistema e objeto de luta. Por um lado, tanto a organização da sociedade como das idéias que nela circulam fazem parte de um mesmo movimento histórico, distribuído através de regimes de manifestações das mais diversas ordens, desde econômica até cultural, nenhuma delas podendo se traduzir em realidade ou origem das demais. Por outro lado, revelando a forte influência das hierarquias sociais sobre as formas de enunciação, o signo (discurso) transforma-se em "arena" importante da luta de classes (BAKHTIN, 1988, p.43). No fundo, optar por prática discursiva ao invés de discurso é assumir uma posição teórica, sublinhando "obrigatoriamente que se considera o discurso como uma forma de ação sobre o mundo produzida fundamentalmente nas relações de força sociais." (CHARAUDEAU; MAINGUENEAU, 2006, p.396).

Como as políticas educativas exprimem relações de força na sociedade, essas relações também vão prevalecer nas práticas discursivas (ORLANDI, 2002, p.40). De sorte que o sentido e a linguagem não se superpõem, mas encerram uma das dimensões constitutivas das relações econômicas e sociais (MAINGUENEAU, 1993, p.188), das relações de saber e poder, não traduzindo o discurso tão somente os sistemas de dominação, mas aquilo 
propriamente pelo que se luta para enfim apoderar. "Todo sistema de educação é uma maneira política de manter ou de modificar a apropriação dos discursos, com os saberes e os poderes que eles trazem consigo." (FOUCAULT, 2004, p.44) Ao mesmo tempo expressando e fazendo parte do universo das transformações sociais, segundo ainda Foucault (1997, p.12), uma prática discursiva se transforma como resultado de modificações ocorridas dentro dela, em outras práticas discursivas ou no âmbito mais amplo das formas de produção, relações sociais e instituições políticas.

Concorre, nessa direção, o fato de que as ideologias não se restringem às idéias, mas ganham sentido sobremodo enquanto forças materiais (PÊCHEUX, 1988, p.129). Um produto ideológico investe uma realidade como qualquer corpo físico mas, além disso, ainda reflete outra realidade exterior. "Tudo que é ideológico possui um significado e remete a algo situado fora de si mesmo." (BAKHTIN, 1988, p.31) Como a ideologia em geral e as ideologias regionais (política, religiosa, jurídica, pedagógica etc.) realizam-se, essencialmente, através dos AIE, o ideológico é inerente tanto ao aparelho quanto a sua prática. "Esta existência é material." (ALTHUSSER, 1992, p.89)

Não por acaso, os grupos sociais acabam intervindo nas políticas públicas para direcionar estas de acordo com suas perspectivas e interesses. Por isso mesmo, é preciso compreender a função que exerce o discurso no campo das práticas não discursivas e, por extensão, o regime e os processos em que se dá a sua apropriação, isto é, o direito e a competência para acessar, falar, entender e investir o discurso nas instituições e tomadas de decisão. Em outras palavras, conforme sugere Courtine (1999, p.16), a questão que se coloca é compreender "como um discurso político 
funciona? O que é enunciar, manter o fio de um discurso, mas também 'repetir', 'lembrar', 'esquecer', para um sujeito enunciador tomado nas contradições históricas do campo político?"

O discurso se define, pois, pela capacidade em relacionar, sistemática e positivamente, seus elementos a outros discursos e a todo um campo não discursivo (FOUCAULT, 2002, p.210). Conforme Pêcheux (1968), retomado por Henry (1990, p.24), o discurso se constitui em instrumento da ação política, cuja função é transformar, através da prática discursiva, as relações sociais e estas, por sua vez, a demanda social. O discurso político, mais particularmente,

não esgota, de forma alguma, todo o conceito político, mas não há política sem discurso. Este é constitutivo daquela. A linguagem é o que motiva a ação, a orienta e lhe dá sentido. A política depende da ação e se inscreve constitutivamente nas relações de influência social, e a linguagem, em virtude do fenômeno de circulação dos discursos, é o que permite que se constituam espaços de discussão, de persuasão e de sedução nos quais se elaboram o pensamento e a ação políticos. A ação política e o discurso político estão indissociavelmente ligados, o que justifica pelo mesmo raciocínio o estudo político pelo discurso (CHARAUDEU, 2006, p.39). 
Ao considerar que toda mudança política pressupõe uma mudança discursiva, ainda que nem sempre concomitante, a $\mathrm{AD}$ reconhece uma relativa autonomia do campo discursivo em relação ao político. De sorte que a prática discursiva constitui não apenas uma das tantas formas da prática política, como sobremaneira um dos domínios mais importantes da estratégia política. Além de ser essencial à determinação dos posicionamentos assumidos politicamente, é mediante o discurso que podemos avaliar "as contradições, as indeterminações e oposições." (FORGET, 1994, p.29) Antes, porém, de evidenciarmos como a própria prática discursiva afeta nosso corpus de análise, faz-se necessário tentarmos reconstruir a sua historicidade, dando ênfase às condições de produção de cada texto selecionado.

\section{CONDIÇÕES DE PRODUÇÃO DO DISCURSO EM TORNO DA EAD}

Inscrevendo-se num cenário, ao mesmo tempo, de educação para o século XXI e de continuidades da política educativa, a escolha do T1 - "Universidade Aberta do Brasil: democratização do acesso à educação superior pela rede pública de educação a distância" - como texto central de nossa análise não poderia ter sido aleatória. Conforme veremos adiante mais detalhadamente, embora volte sua atenção para a educação superior, representa aquele texto um "marco" dos discursos oficiais que, pelo menos, nas últimas seis décadas, têm contribuído para afirmar e legitimar o processo de industrialização do ensino no país que constitui, por sua vez, não apenas a consolidação da política nacional de educação a distância, como também 
a modernização até as últimas conseqüências da política educativa em geral.

A produção, difusão e circulação do T1 acontecem, portanto, em meio a uma conjuntura excepcional, marcada principalmente pela expansão crescente das TICs, da EAD e da mercantilização da educação em todo o mundo; consolidação da SEED e da política nacional de educação a distância; crescimento da demanda e ampliação da oferta de ensino superior a distância e semi-presencial; e incremento da política de inclusão social como um dos pilares deflagradores do segundo mandato do governo Lula. "Buscando revolucionar a educação, rumo à transformação inclusiva, dois grandes temas têm ocupado a agenda do MEC: a democratização do acesso e a qualidade da educação no País." (HADDAD, 2006, p.7)

A EAD teria chegado, enfim, ao seu terceiro estágio no Brasil. Em primeiro lugar, suplantado a fase do idealismo que atribuía à educação a distância a capacidade revolucionária de equacionar os graves problemas educacionais. Em segundo lugar, superado a fase da normalização, responsável por inserir a EAD entre as prioridades da educação nacional, com ênfase para a educação de adultos. "Finalmente, a emancipação reflete os parâmetros em que hoje a EAD é concebida, como única modalidade capaz de absorver os rumos do desenvolvimento tecnológico e, nesse sentido, é proclamada como a educação da era da informação." (FARIAS, 1998, p.90)

Sua importância crescente no Brasil reflete a tendência mundial de incremento da EAD, patrocinada por organismos internacionais como a Organização dos Estados Americanos (OEA), o Conselho da Europa e a Unesco (OILO, 1999; UNESCO, 1999), ensejando à Organização Mundial do Comércio (OMC) a se mobilizar "ativamente 
para suprimir todas as barreiras ao comércio internacional de 'mercadorias educativas'." (NOBLE, 2000) Apropriadas por investidores privados e praticamente sem fronteiras, as tecnologias de EAD favorecem a expansão do mercado educativo, ampliando o alcance e acelerando substancialmente "a reprodução do capital no campo da educação." (BATISTA, 2002)

Aos governos nacionais cabe desenvolver políticas de expansão da EAD que passa a representar o modelo que melhor pode cumprir as prioridades educacionais, "dentro de uma racionalidade superior às modalidades presenciais." (PRETI, 1998, p.24). Não sem motivos, em 2003, o governo Lula inicia seu primeiro mandato considerando que: "A Educação a distância é instrumento essencial para democratizar o acesso à educação, facilitar a formação continuada e elevar o padrão de qualidade da educação." (BRASIL, 2003, p.62)

A própria ênfase do $\mathrm{T} 1$ sobre o Sistema Universidade Aberta do Brasil representa, no fundo, um novo deslocamento de sentido, promovido pela mesma política que, até então, concentrava sua atenção na difusão da TV Escola, ProInfo e Proformação. Esses programas constituem, por sua vez, os ícones do T2 - "Política e resultados 19952002: tecnologias na educação básica", cuja "elaboração" foi incumbida à Diretora do Departamento de Política de Educação a Distância da SEED/MEC. Concebido como "um rápido balanço" das ações da SEED durante os dois mandatos do governo Fernando Henrique Cardoso, o texto representa em última instância um libelo em defesa das "tecnologias na educação básica", tendo em vista que: "Este foi um compromisso assumido no Planejamento Estratégico desenhado para o período 1995-1998. A Secretaria da Educação a Distância vem honrando esse compromisso." (BRASIL, 2002a, p.8) 
Em pleno processo de transição para um governo de oposição, eleito por uma coligação de centro-esquerda (o governo Lula), o T2 é publicado em dezembro de 2002, voltando sua ênfase à "Política e resultados" alcançados por parte da SEED. “Toda a sua vasta produção editorial neste período serve justamente ao propósito de orientar a implementação da política de novas tecnologias na educação pública. Procuram convencer sem impor, liderar sem submeter." (SOUZA, 2002) A pretensão do governo Fernando Henrique Cardoso em liderar as mudanças no sistema educativo, "sem submeter", advém desde quando a TV Escola constitui o carro-chefe da política de EAD.

O T3 - "Dois anos da TV Escola" - tem sua produção, difusão e circulação nesse período, representando o primeiro artigo de uma coletânea em que o próprio presidente da República assina o texto de "Abertura", contendo oito páginas, o dobro da média dos artigos escritos por autoridades e especialistas em EAD do Brasil, Argentina, Canadá, Chile, Colômbia, Espanha, Estados Unidos, França, Inglaterra e México: "acho importante que a gente entenda que o acesso a essas técnicas mais modernas também faz parte do processo de cidadania. Porque é permitir que a população participe dos avanços do progresso técnico que vão ser decisivos nos séculos vindouros." (CARDOSO, 1999, p.15)

Logo no discurso de posse em 1995, por ocasião do seu primeiro mandato, o presidente Fernando Henrique Cardoso faz questão de conclamar o engajamento das "nossas TVs numa verdadeira cruzada nacional pelo resgate da cidadania através do ensino", traduzindo a importância que a TV, particularmente, passa a ter na política educacional (CARDOSO, 1994, p.129). Não por acaso, o T3 integra a coletânea "2 anos da TV Escola", publicada 
pela SEED/MEC em 1999, início do segundo mandato daquele governo. "É mais uma contribuição aos professores e outros profissionais que trabalham com educação a distância, comprometidos com a construção de um novo ensino nas escolas públicas do País." (BRASIL, 1999)

Editada através da "Série de Estudos: Educação a Distância", cuja tiragem em 1999 chega a 110 mil exemplares por título (BRASIL, 2002b, p.30), a coletânea publica, "em versão condensada" (a versão integral seria disponibilizada no site da SEED/MEC), as palestras apresentadas durante o Seminário Internacional sobre os 2 anos da TV Escola, realizado em Brasília, entre os dias 30 de junho e $1^{\circ}$ de julho de 1998. Reunindo tendências e experiências da EAD em nível mundial, o Seminário mostra-se "importante" graças, entre outros, aos seguintes motivos: "Comprovou o valor das novas tecnologias na capacitação de professores" e "reforçou nossa confiança na TV Escola, no momento em que comemorávamos um avanço significativo do Programa em escolas de todo o País" (BRASIL, 1999).

Além de "ter, efetivamente, posto em prática aquilo que era aspiração de todos nós" (CARDOSO, 1999, p.11), o próprio ministro da Educação - também responsável pela "Apresentação" do T2 - é quem assina o T3, fazendo questão de reiterar o seguinte: “Hoje, 50 mil escolas estão assistindo a este seminário, em todo o Brasil. Nos confins da Amazônia, em São Paulo, no Rio de Janeiro - 50 mil escolas estão nos assistindo hoje." (SOUZA, 1999, p.19) De fato, o avanço da EAD no país mostra-se considerável, ao levarmos em conta sobremodo a sua expansão entre o início e o final dos anos 1990, quando a TV Escola já alcançava "50 mil escolas". 
O T4 - "Educação a distância: integração nacional pela qualidade do ensino" - marca essa fase, graças, em particular, a dois fatores de extrema importância: a conjuntura política em que se dá sua produção, difusão e circulação e a proposição de uma política nacional de EAD. Datada de 1992, a publicação do texto coincide com o processo de impeachment e renúncia do presidente Fernando Collor de Mello que, sem precedentes na história do país, altera toda a vida nacional. Tanto que o T4 é publicado em duas versões. Como faz referência ao "Presidente da República" e "Vice-Presidente da República no exercício do cargo de Presidente da República", sugere a primeira versão ter sido editada por ocasião do afastamento de Collor de Mello em 2 de outubro de 1992 e conseqüente ocupação da Presidência pelo seu vice.

A segunda versão (a qual adotamos em nosso corpus) teria sido reeditada logo em seguida à renúncia do presidente e posse definitiva de Itamar Franco, em 29 de dezembro daquele ano. O T4 já se refere a este último como "Presidente da República Federativa do Brasil", embora mantenha o texto a data anterior de sua publicação e a própria ênfase sobre a "modernização" nacional: "A modernização do País passa necessariamente pela educação e esta precisa utilizar os recursos tecnológicos disponíveis para se fazer presente, co-partícipe, do processo de modernização e, sobretudo, promotora e indutora da sociedade do futuro." (BRASIL, 1992, p.9)

Durante o governo Itamar Franco, são esboçadas propostas consistentes de uma política nacional de teleducação e intensificada a cooperação internacional, "em busca da incorporação da experiência estrangeira nas reflexões sobre uma forma brasileira de Educação a Distância" (BRASIL, 1994, p.7). Com efeito, o T4 dedica especial 
atenção à política de EAD que, em plena transição para o século XXI, torna-se cada vez mais estratégica à educação nacional. Elaborado e publicado sob os auspícios da Coordenadoria de Educação a Distância/MEC e apoiando-se, de modo especial, no Programa Um Salto para o Futuro, o texto não deixa de representar um parâmetro importante da política que será retomada, mais adiante, por intermédio do T1, T2 e T3: "O documento contempla a Política e o Programa Nacional de Educação a Distância ou Teleducação, suas tendências e perspectivas." (BRASIL, 1992, p.3)

Essa ênfase sobre uma política de EAD já se faz presente junto ao T5 - "1985: Mensagem apresentada ao Congresso Nacional pelo Presidente da República, João Baptista de Oliveira Figueiredo, na abertura da sessão legislativa". Notadamente, quando consideramos que, além da educação no meio rural e nas periferias urbanas, a valorização dos recursos humanos e o desenvolvimento cultural, dentre as linhas mestras do III Plano Setorial de Educação e Cultura, elaborado para o período 1980-1985, encontra-se o "planejamento e modernização técnico-administrativa" (1985: MENSAGEM, 1987, p.513).

O texto assume uma importância especial, mais precisamente, porque faz parte do documento "A educação nas mensagens presidenciais: 1890-1986", uma espécie de coletânea que reúne os capítulos dedicados à educação por parte das mensagens presidenciais, pronunciadas na abertura das sessões legislativas do Congresso Nacional, desde a Velha até a Nova República. Substituindo a "Fala do Trono" do período imperial, as mensagens representam "uma prestação de contas do Poder Executivo, apresentadas pelo Presidente da República ao Poder Legislativo, e, conseqüentemente, a toda a Nação." (BRASIL, 1987, p.9) 
Organizada pelo Inep/MEC, a coletânea é editada em dois volumes. Enquanto o primeiro destina-se ao período que vai do governo Deodoro da Fonseca (1890) até o governo Café Filho (1955), o segundo volume compreende do governo Juscelino Kubitschek (1956) ao governo José Sarney (1986).

Além de constituir o único texto referente à década de 1980 que coletamos durante nossa pesquisa, faz parte o T5 de uma das mensagens mais importantes à República brasileira, a saber, a última mensagem apresentada por um presidente do Regime Militar, João Figueiredo, em 1985. Por seu turno, inscreve-se esta em uma coletânea publicada em 1987, durante o governo Sarney que inaugura um novo processo de redemocratização no país. Sua produção, difusão e circulação se dão, portanto, numa conjuntura excepcional, marcada pela nova Assembléia Nacional Constituinte, à qual o texto "é especialmente dedicado" e que, segundo o ministro da Educação, precisaria levar em conta as "exigências de um mundo" às portas do século XXI: “Nossa juventude deve ser preparada para entrar no mundo do trabalho, para produzir e dominar uma tecnologia de ponta, pois, do contrário, não ficaremos à altura das necessidades do Brasil de amanhã." (BORNHAUSEN, 1987)

A redemocratização do país tem suas bases lançadas durante ainda o Regime Militar, quando o governo Ernesto Geisel começa a acenar com lampejos de abertura política, cedendo a pressões da sociedade, via o que o presidente batizou de um "processo lento, gradual e seguro de aperfeiçoamento democrático". Durante o governo Geisel, integrante do grupo de militares considerados "intelectuais" da Sorbonne, a administração pública é gerida de forma tecnocrática nos moldes de uma empresa privada. 
Os argumentos direcionados à racionalização são muitos, objetivando construir a imagem de competência burocrática, controle político e legitimidade.

A pressa em lançar planos e programas, especialmente, "em momentos de crise pode ser interpretada como uma forma de discurso para compensar a ausência de decisão; [Geisel chegava] mesmo a dizer que prever uma situação era o mesmo que se resolver um problema pela metade!" (FORGET, 1994, p.99) O T6 - “Projeto Logos II" - é reflexo disso, reportando-se a uma das prioridades daquele governo no campo da educação que, como sugere o próprio nome, vem suceder o Projeto Logos I. O que supõe também que, durante a pesquisa, assim como aconteceu ao T4, nos deparamos com duas versões de texto, preferindo optarmos pelo documento referente ao Projeto Logos II, haja vista reunir, além de um novo projeto, uma espécie de diagnóstico que reaproveita parte do texto anterior.

Em resposta à exigência da Lei 5.692 de 1971, que estabelece a obrigatoriedade da habilitação específica de $2^{\mathrm{o}}$ grau para o magistério de $1^{\mathrm{o}}$ grau, da $1^{\mathrm{a}}$ à $4^{\mathrm{a}}$ séries, e prevê a oferta de cursos supletivos "mediante a utilização de rádios, televisão, correspondência e outros meios de comunicação", o Logos I é implementado como projeto-piloto, no início de 1973, ainda sob o governo Garrastazu Médici. Na forma de ensino supletivo a distância para qualificação de professores leigos, representa o projeto "o começo de uma longa caminhada em busca do tempo perdido." (BRASIL, 1975a, p.12) Se no "Projeto Logos I: avaliação", elaborado no final de 1974 e publicado em 1975, fala-se de uma demanda de "aproximadamente 200.000 professores leigos", logo adiante, o "Projeto Logos II" refere-se a um número estimado em 300 mil docentes não 
titulados (BRASIL, 1975b, p.8), manifestando o T6 um dos maiores esforços envidados pelo governo brasileiro, até então, para a formação e qualificação de professores.

Publicado também em 1975, o texto é elaborado pelo mesmo Departamento de Ensino Supletivo/MEC que, na conclusão do "Projeto Logos I: avaliação", declara que, através do Projeto Logos II, pretender-se-á atingir, gradativamente, "todas as regiões do País, procurando, não importa o tempo necessário, habilitar todos os professores leigos em exercício nas primeiras séries do $1^{\circ}$ grau. Depois, outras etapas serão tentadas, até a plenitude dos objetivos: a Universidade Aberta." (BRASIL, 1975a, p.120) Além de se revestir, de certa forma, do espírito "lento, gradual e seguro" do governo Geisel, a declaração antecipa aquilo que, mais tarde, o T1 encarrega-se de anunciar - a Universidade Aberta do Brasil.

Aliás, assim como praticamente acontece ao T1, o "desenvolvimento econômico", o "fator demográfico", a "era tecnológica" e o "tempo da educação permanente" marcam o T7 - o "Relatório da teleducação". Sua produção, difusão e circulação inscrevem-se no final do governo Médici, em plena Ditadura Militar e do "Milagre Brasileiro", para o qual é essencial que a educação não se restrinja ao âmbito escolar, "mas utilize todos os meios disponíveis que lhe garantam maior rentabilidade e produtividade, cobrindo regiões cada vez mais amplas e envolvendo um número cada vez maior de indivíduos." (BRASIL, 1973, p.1) O texto representa, dessa forma, um documento fundamental desenvolvido pelo Programa Nacional de Teleducação (PRONTEL), órgão vinculado à Secretaria-Geral/MEC e dirigido por uma comissão de representantes dos ministérios da Fazenda, Planejamento e Comunicações. 
Criado em fevereiro de 1972, objetiva o PRONTEL "acelerar o processo educacional e racionalizar" a EAD no país. Neste sentido, concentra sua atenção inicial na elaboração do Plano Nacional de Tecnologias Educacionais (PLANATE) que se destina, entre outros propósitos, a estimular o uso de "técnicas de planejamento, administração, desenvolvimento, controle e avaliação", com vistas ao "melhor aproveitamento" dos programas de teleducação (BRASIL, 1973, p.49). Sob a coordenação do PRONTEL, cabe ao Sistema Nacional de Teleducação (SINATE), composto pelo Subsistema MEC, Subsistema Público e Subsistema Privado, executar as metas, projetos e atividades ligados ao PLANATE.

O T7 destaca, dentre essas ações, o Plano Operativo de 1974 que coloca em prática as diretrizes do PLANATE, objetivando oferecer, "em curto prazo, condições para a operacionalização, em níveis crescentes de eficiência, às atuais entidades do SINATE, ao mesmo tempo que abre caminho para ampliação e aperfeiçoamento do Sistema a médio e longo prazo." (BRASIL, 1973, p.50) Com efeito, mesmo elaborado em 1973, ainda sob a vigência do I Plano Setorial de Educação e Cultura que integra o I Plano Nacional de Desenvolvimento (PND), formulado para o triênio 1972/74, o texto já aponta na direção do novo Plano Setorial para 1975/79 que prevê uma "maior e mais efetiva utilização de tecnologias com vistas a superar os déficits quantitativos e qualitativos de escolaridade." (BRASIL, 1976, p.37)

A preocupação em aplicar "tecnologia avançada" na solução desses déficits deriva, no entanto, desde os primeiros anos do Regime Militar, quando se intensifica a atenção dispensada por parte do Brasil à corrida espacial. Um dos principais objetivos da produção, difusão 
e circulação do "Relatório ${ }^{\circ}$ II" do Projeto Saci (Satélite Avançado de Comunicações Interdisciplinares) resulta daí: "Parece evidente que só um programa radical e corajoso - como o SACI - poderá elevar a quantidade e qualidade da educação em futuro próximo e atingir a meta de oportunidade educacional para todos os brasileiros." (BRASIL, 1969, p.1)

Produzido na forma de um segundo relatório acerca daquele Projeto, o documento aborda a evolução do Saci a partir de maio de 1968, durante o último ano do governo Costa e Silva, que delega sua elaboração à Comissão Nacional de Atividades Espaciais (CNAE), extinta em 1971 e transformada no INPE, o atual Instituto Nacional de Pesquisas Espaciais. Vinculada ao Conselho Nacional de Pesquisas e sediada em São José dos Campos-SP, representando portanto a única instância do nosso corpus discursivo localizada fora da capital federal, a CNAE reúne, no início de 1969, mais de uma centena de pesquisadores que realizam estudos, inclusive de doutoramento fora do país, com o objetivo de subsidiar as decisões governamentais: "No momento, um grupo de engenheiros, educadores, sociólogos e economistas estão investigando a educação por satélite como adição eficaz aos esforços do governo para melhorar e ampliar o sistema educativo da nação." (BRASIL, 1969, p.4).

Mais particularmente, como sugere o próprio título, trata o T8 - "Projeto Saci: relatório n ${ }^{\circ}$ II: parte A" - de uma parte do referido relatório que enfatiza desde as condições de infra-estrutura até o impacto econômico do Saci. Neste sentido, além de defender que "a tecnologia de outras nações terá de ser trazida para o Brasil", até como base "para o lançamento de um satélite brasileiro em meados da década 1970/1980", supõe o texto que o governo 
somente implementará o Projeto se tiver a certeza de seu elevado retorno financeiro.

Dessa forma, parte o T8 literalmente do "conceito de formação do capital humano" de Theodore W. Schultz para chamar atenção sobre o "reconhecimento geral do valor da educação" e, por extensão, sobre os argumentos econômicos em favor da implementação do Projeto Saci. Mesmo considerando que são escassos os trabalhos sobre as taxas de retorno dos investimentos em educação no país, reitera aquele texto: "O uso de novos meios em larga escala, através de uma combinação de satélite e transmissores de terra, parece ser a única solução possível para o problema educacional do Brasil." (BRASIL, 1969, p.49)

Essa convicção, ao que tudo indica, resulta de uma série de estudos desenvolvidos pela CNAE, desde 1966, que culminam, dois anos depois, em um relatório de três volumes a respeito do Projeto Saci. O T9 - "Projeto Saci: parte I" - constitui um texto também importante, sobretudo, porque objetiva transcender aspectos de ordem tecnológica. "Os problemas reais, entretanto, não são técnicos; ao contrário, são políticos, econômicos e sociais. São estes aspectos do projeto que formam a essência deste capítulo." (BRASIL, 1968, p.2-1) O capítulo em questão tem como título "Usos e custos de telecomunicações para nações em desenvolvimento", repousando sua ênfase sobre o sistema de televisão educativa via satélite.

$\mathrm{Na}$ realidade, apesar de relacionar entre suas "Referências" discussões sociológicas como "Educação e sociedade no Brasil", de Florestan Fernandes, já se antecipando ao T8 o T9 baseia-se, essencialmente, na economia da educação e da comunicação e na tecnologia educacional. Além de "The economic value of education" de Theodore W. Schultz, fundamenta o T9 uma série de estudos 
estrangeiros recém publicados, tais como, "Human capital" de Gary S. Becker, "Economic aspects of education" de W.G. Bowen, "Technological progress, capital formation and economic growth" de Robert M. Solow, "The diffussion of innovations" de E.M. Rogers, "Innovation in education" editado por M.B. Miles e "Communication and change in developing countries", editado por D. Lerner e W. Schramm. Chamamnos a atenção, ademais, as várias referências a trabalhos apresentados junto a "AIAA Communications Satellite Systems Conference", realizada em Washington-Estados Unidos, em maio de 1966, pelo Instituto Americano de Aeronáutica e Astronáutica (AIAA).

Tomando como base esse referencial, além de apontar um conjunto de estudos empíricos que permite aos "planejadores educacionais" tirar proveito de informações relativas a vários países onde os "meios de educação de massas" são utilizados para compensar os problemas do ensino e do desenvolvimento, o T9 representa um libelo em defesa do Projeto Saci. O Projeto é considerado uma oportunidade ímpar para o Brasil tornar-se vanguarda na aplicação da tecnologia espacial ao sistema educativo. "Poderemos certamente demonstrar ao mundo as possíveis feições da modernização educacional; devemos guiar pensadores, educadores e construtores da nação na inovação pelo progresso" (BRASIL, 1968, p.2-6).

A ideologia da modernização atribui à educação a alavanca do progresso científico e tecnológico, vinculando-a inexoravelmente ao desenvolvimento econômico. Segundo reconhece o próprio presidente Costa e Silva, essa relação se estabelece de forma tão intensa que, desde o início dos anos 1960, o Banco Internacional de Reconstrução e Desenvolvimento (BIRD), braço do Banco Mundial, passou a financiar "os programas educacionais com a mesma 
objetividade com que financia projetos específicos no campo da energia elétrica." (FORGET, 1994, p.82)

O propósito de "guiar" a nação no sentido da "modernização educacional" advém, porém, desde o processo de redemocratização do pós-guerra, mais precisamente, quando emerge o nacional-desenvolvimentismo nos anos 1950. Exemplo sintomático nesse sentido é o T10 - “A educação e o treinamento por correspondência: histórico e potencialidades" - que, segundo o diretor do Serviço de Documentação do Departamento Administrativo do Serviço Público (DASP), constitui um "oportuno Ensaio que o Serviço de Documentação ora oferece aos estudiosos." (PINTO, 1955, p.4) Último texto constante de nosso corpus discursivo, embora represente o primeiro pela ordem cronológica, trata o T10 de um estudo acerca do ensino por correspondência no mundo, com ênfase para seu desenvolvimento junto a importantes universidades norte-americanas.

Em meados da década de 1950, apesar de não mais assumir tamanha relevância quanto no primeiro governo Getúlio Vargas, o DASP tende ainda a exercer influência sobre a administração pública: "Cumprindo o seu programa de disseminação de uma autêntica bibliografia brasileira das ciências administrativas, lança o Serviço de Documentação do D.A.S.P., com o importante trabalho que se vai ler, o $50^{\circ}$ número da série 'Ensaios de Administração'." (PINTO, 1955, p.3) Os quatro números publicados anteriormente intitulam-se "Alguns aspetos da administração de pessoal", "O mandado de segurança", "Notas sobre o Tribunal de Contas da União" e "Previdência social". Além disso, encontram-se no prelo "Problemas fundamentais dos municípios brasileiros", "Introdução ao estudo de documentação", "Um problema 
de administração escolar", "A era do administrador profissional", "Administração financeira e contábil" e o sugestivo "Burocracia e Democracia".

Embora encontremos entre os elementos pós-textuais do T10 a ressalva de que os "conceitos emitidos nos trabalhos divulgados nesta coleção serão de exclusiva responsabilidade dos autores", em meio aos elementos pré-textuais observamos o seguinte: "Realizados com a colaboração de especialistas nos diversos setores da ciência da administração e campos correlatos, terão por objetivo prestar subsídio aos estudiosos, suprindo, na medida do possível, a carência de bibliografia especializada, do gênero, em língua portuguesa." (PIMENTEL, 1955) Um desses "especialistas" é o "técnico de administração" que, sob os auspícios daquele órgão, publica o T10: “O autor, como revelam a profundeza e o brilho demonstrados no tratamento do assunto, era pessoa indicada para elaborar o oportuno Ensaio" (PINTO, 1955, p.4). Além de diretor geral do DASP entre 1961 e 1962, o autor torna-se diretor da Fundação Getúlio Vargas (FGV) e membro da Comissão de Administração Pública Internacional da ONU (ANTONIO, 2008).

A publicação do T10 ocorre em abril de 1955, durante o governo Café Filho, período em que o DASP ainda se localiza no Rio de Janeiro, sede do Distrito Federal. Sua concepção, porém, remonta ao segundo governo Getúlio Vargas, entre os anos 1952 e 1953, "quando nos foi dado estagiar em alguns dos mais importantes e conhecidos estabelecimentos dessa modalidade de instrução, existentes na grande nação amiga." (PIMENTEL, 1955, p.9) O estágio realizado nos Estados Unidos resulta não apenas em um, mas numa série de trabalhos. 
Conforme as "Referências Bibliográficas" do T10, em 1953, o autor elabora "Uma Escola de Administração para todo o Brasil", projeto destinado à criação de um Departamento de Cursos por Correspondência na Escola Brasileira de Administração Pública e de Empresas (EBAPE) da Fundação Getúlio Vargas (FGV). Em 1954, além do "Projeto de reorganização do ensino por correspondência dos cursos de Administração do D.A.S.P.", publica o artigo "A maior organização do mundo em ensino por correspondência", no número de dezembro da Revista do Serviço Público, atualmente editada pela Escola Nacional de Administração Pública, vinculada ao Ministério do Planejamento. No mesmo ano, publica ainda dois trabalhos através da série "Cadernos de Administração Pública", editada pela EBAPE/FGV: "Pequena bibliografia sobre treinamento" e "Alguns aspectos do treinamento" (FUNDAÇÃO, entre 2002 e 2008), este último reeditado pela mesma FGV, em 1966 (UNIVERSIDADE, 2008).

Em 1955, por sinal, torna-se aquele autor o único a conseguir aprovar mais de uma obra junto à série "Ensaios de Administração" do DASP. De sorte que, ao mesmo tempo em que acontece a publicação, difusão e circulação do T10, já se anunciam novos títulos entre os seus elementos pós-textuais: "A sair, do mesmo autor: 'A educação e o treinamento por correspondência (métodos e processos)" e "'O ensino por correspondência no Brasil (o que é e o que pode ser)"'.

Ao que tudo indica, não é por acaso que aquele autor - e, por extensão, o próprio DASP - mostra-se preocupado em dar continuidade aos estudos a respeito de "práticas, processos e técnicas" que conduzem à "boa organização e administração" do ensino por correspondência, 
"em benefício da educação e treinamento em nosso país" (PIMENTEL, 1955, p.10). O primeiro impulso massivo da educação a distância em nível mundial data de 1905, nos Estados Unidos, motivado pela expansão dos correios e uma maior demanda de mão de obra qualificada, abolindo-se "de vez o princípio da coexistência do professor com o aluno num mesmo lugar, como única forma de educar." (BORDENAVE, 1987, p.14) $)^{11}$

\section{EM BUSCA DA FORMAÇÃO DO DISCURSO DA INDUSTRIALIZAÇÃO DO ENSINO NO BRASIL}

Como vimos acima, destacam-se no bojo do nosso corpus de análise duas materialidades lingüístico-discursivas, representadas pelos textos de número 1 e 10. O T10, aliás, parece inaugurar uma espécie de discurso fundador que, a partir de então, passaria a nortear a política brasileira de educação a distância: "em relação à história de um país, os discursos fundadores são discursos que funcionam como

11 As iniciativas em EAD patrocinadas pelo Estado brasileiro iniciam-se, também, nesse período (PFROMM NETTO, 1976). Em 1910, dá-se a instalação de uma filmoteca no Museu Nacional do Rio de Janeiro que vai gerar um movimento de educadores e intelectuais em torno da utilização do cinema para fins morais e pedagógicos, originando "um intenso debate, em publicações da imprensa diária e em revistas especializadas de diversos setores sociais" (CATELLI, 2003, 2005) e acabando por influir na criação do Instituto Nacional do Cinema Educativo, nos anos 1930. Fundada em 1923, a Rádio Sociedade do Rio de Janeiro por sua vez lança-se ao desafio de trabalhar "pela cultura dos que vivem em nossa terra e pelo progresso do Brasil", transformando-se em emissora do Ministério da Educação e Saúde (atual Rádio MEC) na década seguinte, um ano antes de o Estado Novo criar o Serviço de Radiodifusão Educativa. 
referência básica no imaginário constitutivo desse país. E a nossa tarefa é então mostrar como é que eles se estabilizam como referência na construção da memória nacional." (ORLANDI, 1993b, p.7)

Mas o T10 não se encontra isolado, dividindo com outros discursos - também capitais - a pretensão em ocupar um lugar inaugural, ou mesmo, fundacional, cujo paradoxo é situar-se na história, embora negando-a. Em outras palavras, "na relação de sentido que um discurso fundacional estabelece com seu interdiscurso específico, um discurso que se auto-apresenta como fundacional, precisa produzir uma ilusão de corte ou ruptura com os processos de sentido sedimentados como memória discursiva." (ZOPPI-FONTANA, 1997, p.171-172) ${ }^{12}$.

Abordando um "complexo problema", por sinal, "jamais ventilado com igual extensão em nosso país, sequer em publicações técnicas", o T10 torna a educação e treinamento por correspondência "matéria particularmente importante para a administração de pessoal no Brasil, dadas a extensão do território nacional e as conhecidas deficiências de transporte com que lutamos." (PINTO, 1955, p.3-4) De sorte que restaria aos demais textos do nosso corpus, inclusive ao T1, reafirmar, amplificar e atualizar esse discurso a sua conjuntura sócio-histórica: "pretende-se ampliar as oportunidades de acesso à educação de grande número de estudantes que vivem em regiões distantes dos grandes centros urbanos do Brasil,

12 Como nosso corpus discursivo remonta à década de 1950, não estamos considerando (nem tampouco ignorando) outros potenciais discursos fundadores ou fundacionais que, antes disso, teriam norteado as iniciativas do Estado brasileiro em EAD, conforme sugerem, por exemplo, Pfromm Netto (1976), Federico (1982), Morettin (1995) e Catelli (2003, 2005). 
país privilegiado com dimensões continentais." (MOTA; CHAVES FILHO; CASSIANO, 2006, p.21)

No entanto, ao postular a democratização da educação superior e a formação inicial e continuada de professores, a Universidade Aberta do Brasil não apenas dá continuidade, como tende representar um marco histórico para a educação a distância no País. Razão pela qual partimos nossa análise da sdr 1 como sequência-modelo, na medida em que a consideramos exemplar para percorrer o sistema de enunciabilidade - ou melhor, o discurso da industrialização do ensino - que norteia a política nacional de educação a distância.

\section{"Marco histórico" da EAD}

Compreender um enunciado ou uma sequência discursiva de referência (sdr), esclarece Courtine (1981), implica determinar a pertinência histórica de sua conjuntura, a produção desta seqüência na circulação de formulações transportadas pelas sequências discursivas que se opõem, se respondem e se citam, visando descrever, finalmente, o marco institucional e as circunstâncias enunciativas desta produção. Logo de início, chama-nos a atenção o fato de que o T1 - "Universidade Aberta do Brasil: democratização do acesso à educação superior pela rede pública de educação a distância" - enfatiza a capacidade da SEED em articular a política educativa e o sistema de ensino, com o propósito de promover a utilização intensiva das tecnologias de informação e comunicação no contex to escolar, buscando inovações tecnológicas e metodológicas para a melhoria da qualidade da educação no país.

Ao longo do texto, percebemos que os enunciados utilização intensiva das tecnologias de informação e comunicação, 
inovações tecnológicas e metodológicas e melhoria da qualidade da educação no país - que, de forma incisiva, apresentam-se investidos do discurso da industrialização do ensino - serão retomados constantemente, com apoio de paráfrases, metáforas e metonímias. A análise que esboçamos a seguir tenta dar conta, essencialmente, de como essa enunciabilidade é produzida, difundida e impulsionada a circular ou assumir uma permanente e sistemática circularidade e quais são as suas implicações discursivas e não discursivas.

A situação de enunciação em torno da UAB

A situação de enunciação que engendra o T1, apesar de não referenciada na sdr 1, tem lugar na Secretaria de Educação a Distância do MEC, conforme encontramos repetido às notas de rodapé, constantes da página inicial daquele texto. Como referenda a folha de rosto do livro "Desafios da educação a distância na formação de professores", onde o T1 é publicado, essa produção se dá em Brasília-DF, de onde emana grande parte do discurso pronunciado pelo Governo Federal.

Embora a sdr 1 reporte-se ao ano de 2005, passando a impressão de ter sido produzida nesse período ( o ano de 2005 representará), encontramos somente ao final do texto um tempo, ou melhor, uma data que, tudo indica, deve-se aproximar do período de sua elaboração: 13 de abril de 2006, cujo ano coincide com aquele também referendado na folha de rosto daquela publicação. Mais adiante, quando analisarmos o texto como acontecimento discursivo, perceberemos a importância desse período para a produção do discurso oficial, assim como para sua difusão e circulação. 
Mesmo fato acontece aos sujeitos e ao quadro institucional em que se inscreve o discurso - vamos encontrar suas indicações em outros lugares textuais. Logo à capa da coletânea "Desafios da educação a distância na formação de professores", percebemos que o T1 foi produzido sob os auspícios da SEED, órgão subordinado ao Ministério da Educação do Governo Federal, cujo slogan observamos ali estampado: "Brasil: um país de todos"13. Como se o país fosse território de todos os brasileiros e, ao mesmo tempo, o governo representasse plenamente o povo: "Governo e povo são emparelhados como iguais e correspondentes, criando de novo a ilusão da democracia, equivalência e igualdade." (ROMÃO; ROMÃO, 2005)

O lugar social e a posição de sujeito estão definidos, por sua vez, na abertura do T1. Logo abaixo do título e subtítulo, encontramos declinados os nomes dos três autores e, em notas de rodapé, os respectivos lugares e cargos que ocupam: Professor Titular da Universidade Federal de Santa Maria - RS, Doutor em Física e, atualmente, ocupa o cargo de Secretário de Educação a Distância do MEC; Engenheiro Eletricista, Licenciado em Física e Doutorando em Educação. Diretor de Políticas em Educação a Distância da Secretaria de Educação a Distância do MEC; Bacharel e Licenciado em Física, Mestre em Educação, Coordenador-Geral de Articulação

13 “Todos os slogans podem ser classificados como autoritários, justamente por não oferecerem aos seus interlocutores a possibilidade da reversibilidade nos papéis da interlocução, muito embora alguns deles simulem um efeito de dialogismo ao evocarem o interlocutor na materialidade discursiva. Contudo, esse destinatário não é especificado, é indiferenciado, pode ser um eleitor em separado e/ou o conjunto dos eleitores de uma cidade, de um estado, de um país, entre outros." (BARONAS, 2000, p.80) 
Institucional em Educação a Distância da Secretaria de Educação a Distância do MEC.

Ainda que, hierarquicamente, tenhamos representadas aí as figuras do chefe e assessores, não foi qualquer um destes últimos que compôs a equipe de autores. Conforme veremos de forma detalhada a partir da análise das regularidades e continuidades discursivas da sdr 1, a SEED, as políticas (projetos e programas) em EAD e a articulação institucional aparecem entre os enunciados mais recorrentes e que produzem os principais efeitos de sentido.

Por outro lado, textualmente a sdr 1 não faz referência a um destinatário concreto ou específico. Ele é evocado, no entanto, por intermédio de estratégias discursivas. Quando os autores elencam uma série de instâncias que representam os parceiros de projetos da SEED, acabam tendo como horizonte de seu discurso esses mesmos parceiros. Entre instituições objetivas, reportam-se eles às demais secretarias e órgãos do MEC, instituições de educação superior, Secretarias Estaduais de Educação, demais Secretarias do MEC, Fórum das Estatais pela Educação, instituições federais de educação superior, Estados e Municípios. Entre as referências vagas, encontramos os sistemas de ensino, as redes de colaboração, os novos e diferenciados partícipes e as três esferas governamentais. Concorre para essa evocação, como demonstraremos adiante, o fato de a parceria representar uma regularidade discursiva cara àquela sequência.

Acrescentaremos a esses parceiros uma série de outros destinatários que inclui desde o público-alvo mais importante ao sujeito do discurso - "alunos, professores e gestores de escolas públicas de ensino fundamental, médio e de instituições públicas de ensino superior" (BRASIL, 2006g), até pesquisadores, especialistas, técnicos e 
potenciais leitores interessados em EAD. De uma forma ou de outra, nosso locutor acaba construindo seu texto a partir das relações discursivas que pode estabelecer com o seu receptor potencial ou eventual: "seu texto é de alguma maneira 'composto sob medida' e reflete a imagem que ele tem do destinatário através dos discursos que lhe faz e da maneira como se dirige a ele." (FORGET, 1994, p.67) Não estivessem pensando em um amplo universo de destinatários, os autores não sentiriam a necessidade de agregar a um discurso predominantemente autoritário um texto de natureza didática que atravessa quase todo o T1, conforme veremos no decorrer da nossa análise.

Vozes e silêncios que calam e falam sobre a $U A B$

À medida que são evocados como destinatários, os parceiros da SEED acabam sendo negligenciados como sujeitos da história, ou melhor, ficam relegados à condição de sujeito silenciado. Apesar das referências a potenciais instâncias de interlocução, incluindo desde os sistemas de ensino, passando pelas instituições de educação superior e indo até as três esferas governamentais, não encontramos na sdr 1 indícios de polifonia, enquanto os vestígios de polissemia apresentam-se reduzidos. Muito mais em se tratando de um discurso de natureza oficial, falar da política de EAD/SEED/Projeto UAB pressupõe o domínio, também, de uma política do silêncio que "se define pelo fato de que ao dizer algo apagamos necessariamente outros sentidos possíveis, mas indesejáveis, em uma situação discursiva dada." (ORLANDI, 1997, p.75)

Ao longo do T1, essa situação também não sofre maiores alterações, até porque a maioria das instâncias de enunciação evocadas remete à esfera do Governo Federal, 
configurando um discurso oficial por excelência. Ainda assim, a ênfase do texto é dispensada aos órgãos e programas na área de educação: $M E C, S E E D$, INEP, Fórum das Estatais pela Educação, Plano Nacional de Educação, Projeto $U A B$. Ademais, os autores baseiam-se o tempo todo em marcos regulatórios, cuja essência é ditar o que se deve fazer - Constituição Federal, Lei de Diretrizes e Bases da Educação e respectivas regulamentações para $E A D$, destacando-se o Edital de Convocação, isto é, o Edital no 1 da SEED, de 16/12/2005, que trata da Chamada Pública para seleção de pólos municipais de apoio presencial e de cursos superiores de educação a distância.

Muito embora relacione ao final uma série de onze Referências Bibliográficas sem evocá-las uma única vez ao longo do texto, à exceção da referência implícita Diálogo para a cidadania e inclusão - Texto-Base do Fórum das Estatais pela Educação e do documento explícito Projeto Universidade Aberta do Brasil, somente encontramos vestígios dessa bibliografia quando cotejamos seus enunciados àqueles que marcam seja a sdr 1 seja o T1 no seu conjunto: Educação a Distância no Brasil; Diálogo para a Cidadania e inclusão; Novas Tecnologias e Mediação Pedagógica; Hipertexto, fechamento e o uso de não-linearidade discursiva; Universidade Aberta do Ministério da Educação e Cultura; Sala de aula interativa.

Esse ocultamento ou silenciamento da fala do outro, contudo, não se dá de forma aleatória. Ele tem um funcionamento próprio que depende, sobremaneira, das posições que os locutores ocupam no texto, (pre)tendendo preencher todos os papéis passíveis ao sujeito e os silêncios possíveis ao próprio discurso. Se o "vazio" da linguagem não representa uma espécie de falta, mas de horizonte ou de "incompletude constitutiva da linguagem", o silêncio 
funciona então como fundamento essencial à polissemia: "mais se diz, mais o silêncio se instala, mais os sentidos se tornam possíveis e mais se tem ainda a dizer." (ORLANDI, 1997, p.71) Se tentar tomar a palavra e ocupar o silêncio até as últimas conseqüências pode ser impossível ou redundar em contradição, não deixa de evidenciar o emprego de uma estratégia discursiva.

Num primeiro momento, percebemos que os autores do T1 ocupam a posição de um sujeito determinado, ainda que implícito na desinência verbal ou no pronome oblíquo átono. Além da fácil determinação do seu nome e da posição que ocupa, como vimos acima, temos um sujeito que faz questão de se situar no discurso, não apenas face ao próprio texto e ao objeto discursivo, bem como face a si mesmo e ao seu (potencial) interlocutor. Mesmo que no meio da seqüência decida tomar uma posição de afastamento, situando-se como sujeito indeterminado expresso pela forma do verbo - propor modelo alternativo, o sujeito discursivo assume a palavra como "sua" reiteradamente.

No início da sdr 1, coloca-se ele por duas vezes, repetindo o verbo poder de forma diferente, embora a forma negativa empregada - Não poderíamos - não altera o propósito de imprimir um efeito de positividade - podemos. No final da seqüência, os locutores situam-se ainda mais incisivamente face ao discurso que produzem - nos colocando, assumindo sua autoria como já determinada em um tempo passado - elaboramos, quer dizer, no pretérito perfeito do indicativo que refere um acontecimento já ocorrido ou concluído e que, numa primeira instância, está posto e não permite mais ser alterado.

Num segundo momento, os autores assumem a posição de um sujeito competente (CHAUI, 1981) que não se contenta apenas em se colocar no discurso, mas faz 
questão de acentuar sua competência como sujeito falante. Em vários momentos, reitera ele o fato de não se encontrar ali por acaso, mas porque domina o objeto discursivo eficientemente. Mesmo a sdr 1 tendo a função de introduzir parcialmente o T1, ressalta aquele sujeito o cuidado que tem em não negligenciar o que goza realmente de importância - Não poderíamos deixar de citar - e de assumir com segurança suas posições ou convicções - podemos afirmar. Acentua ele, inclusive, não temer qualquer questionamento - nos colocando abertos ao diálogo, até porque não fora qualquer um que recebeu a incumbência ou fora convidado a escrever aquele texto. Conhecendo e concebendo o Projeto UAB como conhecem/concebem, ao afirmar elaboramos este artigo, é como se aqueles autores reafirmassem sempre que nós - e mais ninguém - é que fomos capazes de elaborar este artigo.

Num terceiro momento, os autores exercem a posição de um sujeito autorizado, capaz não só de falar com a devida competência sobre o objeto, assim como de representar no discurso a autoridade investida no cargo que ocupa. Em princípio, não é preciso ser diretor do Departamento de Políticas em EAD nem coordenador geral de Articulação Institucional em EAD da SEED para falar de seus programas; porém, se assim o for, mais credibilidade o discurso assumirá: Não poderíamos deixar de citar os programas TV Escola e Proinfo; Projeto Universidade Aberta do Brasil; Sistema Universidade Aberta do Brasil. Do mesmo modo, não é necessário ser secretário da SEED para enfatizar seus êxitos; porém, se assim o for, mais peso o discurso ganhará: a SEED consolidou-se como referência internacional na área de educação a distância e de tecnologias educacionais; podemos afirmar seu caráter estratégico para a educação brasileira; Grande parte do sucesso alcançado pela SEED. 
Como gostariam de dizer aqueles autores, elaboramos este artigo porque, independentemente de termos sido incumbidos ou convidados, estamos já-autorizados a gozar do direito pleno de falar pelo (tal como) quadro ideológico-institucional que representamos. Considerando, além disso, que esse quadro (SEED/MEC/Governo Federal) se inscreve em um governo eleito nas urnas em 2002, através de uma coligação de centro-esquerda (PT, PL, PCB, PC do B e PMN) que obtém quase 53 milhões de votos ou dois terços dos votos válidos, em uma conjuntura democrática de inícios do século XXI, poderíamos acrescentar que os locutores assumem, também, uma posição de sujeito legitimado. Um sujeito a quem se atribui não apenas o dever, mas o direito de falar em nome do Estado brasileiro, mais particularmente, de sua política nacional de educação a distância, incluindo seu órgão gestor (SEED) e as ações por ele conduzidas, dentre as quais o Sistema UAB.

A possibilidade de um sujeito legitimado ajuda-nos a entender porque, ao justificar o Projeto $\mathrm{UAB}$, os autores do T1 carregam em metáforas e metonímias, retomando e dimensionando enunciados da sdr 1 de forma ampla, categórica e contundente: $o$ Projeto $U A B$ representa mais que um programa governamental, configura-se como programa de nação; educação superior para todos, com qualidade e democracia; desafio permanente para construção de um projeto nacional sustentável e inclusivo.

UAB como estratégia dialógica

Esse desvendamento do jogo discursivo que estabelece a ênfase sobre a voz do eu e o ocultamento ou silenciamento do outro nos permite caracterizar o discurso que prepondera na sdr 1 e, por extensão, no T1 como um todo. 
Assim como os demais textos da coletânea "Desafios da educação a distância na formação de professores", o T1 segue inicialmente como gênero os moldes de um artigo de natureza acadêmica, com introdução, desenvolvimento, conclusão e referências bibliográficas, conforme fazem questão de anunciar seus autores na própria sdr 1 : elaboramos este artigo com o objetivo de apresentar o Projeto Universidade Aberta do Brasil.

Por isso mesmo, não esquecem eles de empregar elementos de ordem científica que tendem atribuir maior confiabilidade e credibilidade ao texto, como algumas definições destacadas em notas de rodapé: Conjunto de tecnologias apropriadas para coleta, armazenagem...; Educação ou formação continuada ao longo da vida é um conceito...; a contextualização do objeto: Introdução 4 Alguns dados sobre oferta e atendimento na educação superior brasileira 4 Alguns dados sobre docentes e formação docente no Brasil 4 O Projeto UAB no Fórum das Estatais pela Educação 4 O Projeto-Piloto com o Banco do Brasil 4 O Edital de Convocação 4 Projetos encaminhados para avaliação; e a recorrência a documentos, bases de dados, gráficos, tabelas e uma gama de dados estatísticos atualizados. O uso de recursos acadêmico-científicos acaba contribuindo para o T1 incorporar um tipo de linguagem fortemente didática. A sua utilização pressupõe que o destinatário não sabe nada sobre o objeto; conhece o objeto de forma apenas superficial; encontra-se desatualizado sobre suas tendências e perspectivas; ou mesmo, precisa ser esclarecido sobre suas dimensões e conseqüências.

$\mathrm{Na}$ própria sdr 1, até por seu caráter introdutório, os autores tentam orientar e facilitar a leitura o máximo possível. Em tom professoral, pontua o sujeito do discurso que a história da Secretaria de Educação a Distância tem início em 1995, quando foi criada no âmbito do Ministério da 
Educação, deixando a sugestão, portanto, de que o órgão origina-se e se mantém vinculado à esfera do Governo Federal. Desde sua criação, acrescenta ele, a SEED (sigla que é reiterada, pois, além de ajudar o texto a se tornar conciso, contribui para a incorporação de uma memória discursiva à instituição) tem atuado, quer dizer, tem permanecido fiel à atuação inicial, com o propósito muito claro de promover a utilização intensiva das tecnologias de informação e comunicação no contexto escolar.

Ressalta o sujeito do discurso, ainda, que o sucesso alcançado pela SEED (síntese de sua condição de referência internacional em EAD e de seu caráter estratégico para a educação brasileira), nesses dez anos de vida (o que reforça a idéia de que a instituição tem uma história importante a ser resgatada), deve-se em Grande parte a uma estratégia também bastante objetiva: trabalho colaborativo com os parceiros de projetos que são reiteradamente arrolados. Sequenciando essa trajetória de sucesso da SEED, chama atenção aquele sujeito que $o$ ano de 2005 representará um marco histórico para a educação a distância no País, não esquecendo de incorporar ao discurso um caráter heróico-narrativo, típico de texto didático-literário.

O acontecimento responsável por esse marco histórico, salienta o sujeito do discurso, é a criação do Projeto Universidade Aberta do Brasil, um nome pomposo que segue uma denominação empregada em todo o mundo (Universidade Aberta) para dar conta de um projeto ambicioso, sobretudo, em países continentais como o Brasil. Além da sigla acrescentada logo em seguida (“UAB”), o Projeto UAB ganha duas variações nominais - rede nacional de educação a distância e Sistema Universidade Aberta do Brasil. Esta última, inclusive, é enfatizada - a qual estamos denominando Sistema Universidade Aberta do Brasil, empregando-se assim um recurso que, ao invés de confundir, 
torna-se uma estratégia retórica para reter o objeto na memória discursiva. Aliás, apesar de sua importância já ressaltada, não é a SEED nem outros programas por ela conduzidos que se situam como eixo central do texto produzido: elaboramos este artigo com o objetivo de apresentar o Projeto Universidade Aberta do Brasil (ainda que este mantenha relação intrínseca com aquela Secretaria).

A intenção declarada de apresentar o Projeto UAB presente no enunciado acima evidencia que, associada a uma linguagem didática, porém com repercussões bem mais amplas quando consideramos o campo conflituoso da política, sobressai na sdr 1 uma estratégia discursiva que se revela importante ao discurso oficial - uma estratégia, recorrentemente, de natureza dialógica (BAKHTIN, 1988, 1992, 1997). Num primeiro momento, essa estratégia parece propor a idéia de uma heterogeneidade discursiva, a qual pressupõe o caráter quase nunca homogêneo do próprio texto que, além de acionar tipos diversos de seqüências textuais, gêneros etc., ver-se perpassado por discursos provenientes de outras fontes enunciativas.

Num segundo momento, a estratégia dialógica busca provocar repercussões junto ao próprio campo discursivo. Ao afirmar elaboramos este artigo com o objetivo de apresentar, deixa-se transparecer que não se trata de impor o Projeto $\mathrm{UAB}$, mas de apenas e tão somente apresentá-lo aos seus potenciais parceiros, o que pressupõe colocá-lo em circulação e discussão permanente. Como costuma fazer parte da atitude dialógica assumir uma condição de humildade e de respeito perante o outro, não perde a oportunidade o sujeito do discurso de se resguardar como sujeito cognitivo. Dizer Sem a pretensão de esgotar revela um sujeito despretensioso com qualquer possibilidade de dar conta do objeto em sua plenitude, admitindo não só sua incapacidade de onisciência, assim como a própria incompletude 
do discurso. Como estratégia discursiva acrescenta, ainda, sempre nos colocando abertos ao diálogo, assinalando que a atitude dialógica não é de agora e representa uma regularidade - sempre; além de demonstrar que se trata de assumir, em que pese os riscos, uma postura política e ética nem sempre adotada - abertos ao diálogo.

A estratégia dialógica presente na sdr 1 , num terceiro momento, pretende exercer influência além do âmbito discursivo. Depois de nomear e reconhecer o papel importante de uma série de instâncias - em destaque as instituições de educação superior, as Secretarias Estaduais de Educação e as demais Secretarias do $M E C$, prefere o locutor tratar o outro como igual e de forma íntima, como parceiros de projetos, redes de colaboração, novos e diferenciados partícipes. A referência vaga, porém abrangente aos diversos parceiros, que permite não excluir ou não negligenciar nenhum deles, torna-se útil mais ainda para reforçar a adesão e mobilização em torno do Sistema UAB.

Converge o discurso, por isso mesmo, para uma ênfase sobre a co-responsabilidade do outro. Assim como acontecera à SEED, a participação efetiva dos antigos, novos e diferenciados parceiros revela-se de fundamental importância para o sucesso da UAB. Como reitera insistentemente o sujeito do discurso, não há como pensar em um sistema concebido como tal sem a intensa articulação, o trabalho colaborativo, a estreita relação, a união de esforços entre todos e, de modo especial, entre as três esferas governamentais. Muito mais do que uma convocatória ao voluntariado, a estratégia dialógica apela para uma espécie de discurso do comprometimento que (re)clama às instituições aderir ao Projeto UAB, sob pena não só de perder o rumo da história, como também de descumprir sua missão social; como se boa parte delas - para não dizer, o seu conjunto 
- já não tivesse que fazê-lo por força de obrigação institucional, ou mesmo, dependência econômico-financeira.

O que não deixa de significar um processo de interpelação (ALTHUSSER, 1992), mediante o qual, além de "interpelar" a si próprio por intermédio dos autores do texto, o sujeito do discurso interpela o outro, representado naquelas instituições, a conceber como natural aquilo que é fruto de assujeitamento. Fato este que nos ajuda a compreender como a ideologia "recruta" seus sujeitos, ou melhor, como os indivíduos de modo geral "recebem como evidente o sentido do que ouvem e dizem, lêem ou escrevem (do que eles querem e do que se quer lhes dizer), enquanto 'sujeitos-falantes'." (PÊCHEUX, 1988, p. 158) De todo modo, na conjuntura contemporânea, a estratégia dialógica acaba se revelando importante para relativizar ou escamotear um discurso que, no fundo, configura-se como predominantemente autoritário.

\section{Um discurso predominantemente autoritário}

Seguindo a concepção de Orlandi (1996a), para dar conta do tipo de discurso que atravessa a sdr 1 poderíamos empregar critérios de diversas ordens. A começar por critérios presos a normas institucionais, o que nos permitiria reduzir a análise à tipologia do discurso governamental. Além das inúmeras marcas textuais que apontam nessa direção (MEC, SEED, Programas TV Escola e Proinfo, $U A B$ etc.), o enunciado elaboramos este artigo com o objetivo de apresentar o Projeto Universidade Aberta do Brasil, dificilmente, seria pronunciado por outra instância que não a do Governo Federal. Não caberia ao discurso jornalístico ou jurídico, por exemplo, apresentar o Projeto UAB, mas analisar, discutir ou questionar as suas implicações, com o 
mínimo de rigor, objetividade e imparcialidade, critérios normalmente atribuídos a essas instâncias.

Poderíamos optar, por outro lado, por critérios vinculados a domínios de conhecimento que apontariam para um discurso de natureza acadêmico-científica. Uma tipologia que já assinalamos como recorrente na sdr 1, por força da caracterização do gênero textual como artigo e do uso de uma linguagem didática, mas que não nos possibilita ainda apreender a essência do discurso. O que observamos é que os locutores se apropriam do discurso científico, marcado tradicionalmente por critérios de credibilidade que superam o discurso governamental, a partir de um lugar social que remete à academia (Professor...), porém de uma posição de sujeito marcadamente institucionalizada (Secretário...).

Haveria a possibilidade, ainda, de adotarmos como parâmetro critérios formais ou estruturais, concebendo o discurso como uma dissertação que não deixa de empregar recursos da narração - Desde sua criação em 1995 - e da descrição, tais como, parceiros de projetos, em destaque as instituições de educação superior, as Secretarias Estaduais de Educação e as demais Secretarias do MEC. Além de podermos considerar que a própria sdr 1 estrutura-se na forma tradicional da seqüência introdução (apresentação do tema-objeto: Projeto UAB), desenvolvimento (discussão de suas implicações: importância na consolidação do Sistema Universidade Aberta do Brasil) e conclusão (considerações finais ou inferências: marco histórico para a educação a distância no País), percebemos que a dissertação aí empregada é mais de ordem argumentativa do que expositiva. Acentuando, por exemplo, em podemos afirmar seu [SEED] caráter estratégico para a educação brasileira, os locutores não deixam de induzir seus parceiros a assumir tal afirmação 
igualmente como sua, com maiores chances, portanto, de espelhar a verdade.

Em contrapartida, do mesmo modo que Orlandi (1996a, p.152), preferimos adotar uma tipologia capaz de "incorporar a relação da linguagem com suas condições de produção." No estabelecimento dessa tipologia ganham importância as características da interação e da polissemia, derivando da primeira o critério de reversibilidade que determina a dinâmica da troca de papéis entre os sujeitos da enunciação e, da segunda, o critério da relação desses sujeitos com o objeto discursivo. Considerando, então, o que define aquela autora como tipos de discurso, não encontramos na sdr 1 marcas de um discurso lúdico (em que a reversibilidade é total e a polissemia não tem limites) nem consideravelmente de um discurso polêmico (em que a polissemia se apresenta controlada e a reversibilidade ocorre sob certas condições), mas a predominância de um discurso autoritário.

O que percebemos, na verdade, é que tanto a sdr 1 como o T1 no seu conjunto estão assentados em um discurso autoritário, caracterizado pelo fato de que "a reversibilidade tende a zero, estando o objeto do discurso oculto pelo dizer, havendo um agente exclusivo do discurso e a polissemia contida." (ORLANDI, 1996a, p.154) Um discurso, por assim dizer, que visa a assimetria de cima para baixo, é estratégico e pretende impor discursivamente a verdade, cuja tradução parece se manifestar no seguinte enunciado categórico: o ano de 2005 representará um marco histórico para a educação a distância no País.

Mesmo utilizando uma estratégia dialógica que prega a aproximação aos diferenciados partícipes, o sujeito do discurso atribui-se de antemão uma humildade e uma capacidade inata que, ao tempo que sugerem, tendem a inibir 
a possibilidade de interlocução. Vejamos: Sem a pretensão de esgotar a complexidade e riqueza intrínsecas à temática em questão, e sempre nos colocando abertos ao diálogo. Indicando o fragmento Sem a pretensão de esgotar a complexidade e riqueza que, se já não é possível aos próprios locutores dar conta do objeto discursivo, a partir dos lugares sociais e das posições privilegiadas que ocupam, pouca contribuição restará a ser dispensada por parte do outro.

$\mathrm{O}$ advérbio sempre indica, por sua vez, que, como o que se afirma textualmente já é fruto de um diálogo contínuo, não há razões para debate nem questionamento. Até porque seriam consistentes os fatos reportados: seu caráter estratégico para a educação brasileira; Grande parte do sucesso alcançado pela SEED nesses dez anos de vida, se deve à estratégia de trabalho colaborativo; sua importância na consolidação da rede nacional de educação a distância; em estreita relação com os Estados e Municípios; cristalizando a união de esforços das três esferas governamentais.

Enquanto o discurso lúdico tende a representar o extremo da polissemia e o discurso polêmico o equilíbrio entre esta e a paráfrase, a tendência do discurso autoritário é reproduzir o processo parafrástico, fazendo permanecer o mesmo sentido, ainda que nas formas as mais diversas possíveis (ORLANDI, 1996a, p.155). Os dois segmentos que introduzem a sdr 1 e o próprio T1 são exemplares nesse sentido, principalmente, quando os consideramos como constituídos da seguinte forma:

- a Secretaria de Educação a Distância (SEED) do Ministério da Educação tem atuado transversalmente às demais secretarias e órgãos do $M E C$ não é a mesma coisa que em intensa articulação com os sistemas de ensino; porém, a Secretaria de Educação a Distância 
(SEED) do Ministério da Educação tem atuado transversalmente às demais secretarias e órgãos do $M E C$, bem como em intensa articulação com os sistemas de ensino se completa, na medida em que atuado transversalmente pressupõe intensa articulação e vice-versa, ao passo que sistemas de ensino não deixam de evocar secretarias e órgãos do MEC e vice-versa.

- os programas TV Escola e Proinfo que constituem dois importantes pilares, também, não podem ser confundidos com a SEED consolidou-se como referência internacional na área de educação a distância e de tecnologias educacionais; contudo, os programas TV Escola e Proinfo [...] constituem dois importantes pilares sobre os quais a SEED consolidou-se como referência internacional na área de educação a distância e de tecnologias educacionais se completa, à medida que os programas TV Escola e Proinfo e a SEED estão visceralmente associados, do mesmo modo que importantes pilares e referência internacional traduzem paráfrases que tanto podem se aplicar àqueles programas como à SEED.

Claro que não se pode entender o discurso do Estado brasileiro sem levar em conta o emaranhado e as contradições surgidas no seu interior. Exemplo disso é que, até 1979, o discurso do Regime Militar apresenta-se fortemente monológico, reconhecendo apenas os discursos referentes à mesma formação ideológica. Apesar do autoritarismo ainda se manifestar nos inícios da década de 1980, os discursos vão comportar modificações substanciais, revelando-se o discurso oficial muitas vezes contraditório e perdendo seu caráter homogêneo para o discurso oposicionista (FORGET, 1994, p.168). O discurso 
predominantemente autoritário compreende uma regularidade discursiva presente na própria sdr 1 e, por extensão, a predominância de fragmentos da industrialização do ensino não somente aí, assim como ao longo do T1 e do conjunto do discurso que norteia a política nacional de educação a distância.

\section{As regularidades discursivas da $U A B$}

Analisando a sdr 1 do ponto de vista do par regularidade/descontinuidade do discurso, vamos perceber que o sujeito do discurso repete uma série de marcas ou propriedades textuais, ao longo de toda a seqüência. Esses elementos demarcam o texto não apenas de maneira formal, como também discursiva, ordenando o funcionamento do discurso a partir de um conjunto de fragmentos e enunciados que, basicamente, referem-se a cinco temas ou objetos: TICs/EAD, SEED/MEC, UAB, parceria e, por último, democratização e qualidade da educação. Sob o domínio de famílias parafrásticas, o discurso autoritário tenta produzir efeitos de sentido, ditando o que interessa e é prioritário saber a respeito da Universidade Aberta do Brasil.

Acompanhando a distribuição dos fragmentos e enunciados através dos parágrafos ou segmentos que compõem a sdr 1 (1, 2 e 3), podemos melhor observar como esse discurso se organiza. Importa entendermos antes de tudo, insistem os locutores, que a UAB reflete o primado da (1) utilização intensiva das tecnologias de informação e comunicação (TICs, nomenclatura usualmente adotada na literatura internacional) na sociedade contemporânea e, particularmente, no contexto da escola. Promover tais tecnologias implica nada mais do que fomentar (1) inovações 
tecnológicas e metodológicas, já experimentadas e aprovadas lá fora, imprescindíveis também à educação nacional. Sobretudo à (1) educação a distância - (2) educação a distância - (3) educação a distância (reiteração esta que reforça a nossa memorização e própria opção pela modalidade de $E A D$, como vai ser nomeada no restante do T1), onde as (1) tecnologias educacionais (denominação mais antiga) e os conteúdos multimídia (nome atualizado dos produtos tecnológicos, às vezes, usados como sinônimos de TICs) são empregados de modo especial.

Dessa forma, salientam aqueles locutores, a UAB não surge do acaso, mas inserida no bojo da política nacional de EAD, capitaneada de modo exemplar pela (1) Secretaria de Educação a Distância (SEED) do Ministério da Educação. Depois de vermos, durante dez anos, aquela Secretaria ter atuado transversalmente e em intensa articulação com as diversas instâncias governamentais e não governamentais, não há como não concordar com o (2) sucesso alcançado pela SEED. Estão a nos provar isso o seu caráter estratégico para a educação brasileira, principalmente, em tempos de globalização, e o incomensurável fato de que a SEED consolidou-se como referência internacional, justo num momento em que o Brasil desponta no cenário da geopolítica mundial. Sendo objeto de reiteração que também não é aleatória - (1) SEED - SEED - (2) SEED, a Secretaria não aparece no terceiro parágrafo da sdr 1 , posto que é substituída aí pela própria $\mathrm{UAB}$.

Em princípio, fazem questão de acentuar os locutores, devemos conceber a UAB como mais um dentre tantos (1) projetos e programas, programas e (2) projetos conduzidos pela SEED, o que, mais uma vez, reforça o seu trabalho amplo, sistemático e diligente. Com ênfase para os (1) programas TV Escola e Proinfo, cujos impactos junto ao 
ensino fundamental e médio são conhecidos, responsáveis por criar as linhas mestras de nossa atuação exitosa em nível nacional e mundial. Semelhantemente, precisamos vislumbrar que o (2) Projeto Universidade Aberta do Brasil (UAB) - (3) Projeto Universidade Aberta do Brasil (desta feita, é a UAB que deixa de ser reiterada no primeiro parágrafo, sendo ali representada mediante a SEED), também, tem pretensões ambiciosas. Além de tornar realidade nossa (3) rede nacional de educação a distância, capaz portanto de levar educação superior a todos os rincões do país, o Sistema Universidade Aberta do Brasil atualiza-nos em relação ao que há de mais avançado no mundo em termos de educação, a saber, a universidade virtual e global.

A idéia de rede e de Sistema, explicam aqueles locutores, pressupõe situarmos a UAB como resultante de uma parceria permanente e sistemática. Parceria esta que se apóia na experiência de uma década de (1) intensa articulação e (2) estratégia de trabalho colaborativo da SEED (o que reforça o seu papel estratégico em nível nacional e mundial) com os diversos parceiros de projetos, quer dizer, com membros de uma sociedade ou comunidade cujos interesses são comuns. Destacando-se entre eles as (1) demais secretarias e órgãos do MEC, os sistemas de ensino, o contexto escolar, (2) as instituições de educação superior, as Secretarias Estaduais de Educação e [para não esquecermos] as demais Secretarias do MEC.

Além de herdar essas antigas redes, acrescentam os locutores, a UAB vem mobilizar (2) novas redes de colaboração. Contribuirá nesse sentido, de forma também substancial, a (3) estreita relação (sinônimo de intensa articulação) e união de esforços (paráfrase de estratégia de trabalho colaborativo) que estabeleceremos com outras instâncias de cooperação. Entre os (2) novos e diferenciados partícipes 
- que, aí, substituem os parceiros de projetos, precisamos salientar o papel do (3) Fórum das Estatais pela Educação que, em parte, assume o lugar reservado às demais secretarias e órgãos do MEC; das instituições federais de educação superior que evocam as instituições de educação superior, com ênfase para aquelas vinculadas à esfera federal; dos Estados e Municípios, o que retoma, mas vai além das Secretarias Estaduais de Educação; das três esferas governamentais - SEED/MEC e, para não esquecermos, Estados e Municípios; enfim, da nossa educação superior pública como um todo.

Nesse sentido, completam aqueles locutores, a UAB objetiva garantir, acima de tudo, a democratização e a qualidade da educação. A (1) melhoria da qualidade da educação no país, uma das metas essenciais do governo Lula ${ }^{14}$, confunde-se, obrigatoriamente, com a necessidade de adotarmos uma política de EAD que, assentada em importantes pilares (antes com os programas TV Escola e Proinfo, hoje com o Projeto Universidade Aberta do Brasil), consolide-se como referência internacional (assim como a SEED) e assuma caráter estratégico para a educação brasileira, acrescentando-se a

14 "Os programas governamentais destinados a aumentar o número de universitários no Brasil são responsáveis por uma 'pequena revolução' no sistema educacional, disse hoje (17) o presidente Luiz Inácio Lula da Silva. Ele destacou, em seu programa semanal de rádio Café com o Presidente, os programas de concessão de bolsas de estudo e de reestruturação das universidades federais [...] O ensino de base foi outro tema do programa [...] 'Nós não podemos esquecer que no ano passado nós lançamos o Plano de Desenvolvimento da Educação - o PDE. Esse plano estabeleceu 40 ações que vão desde a construção de creches até as bolsas de pós-doutorado. Mas a ênfase do programa é a qualidade da educação básica', disse." (BRASIL, 2008a) 
este uma estratégia de trabalho colaborativo. Além de (2) inovar (o que evoca as inovações tecnológicas e metodológicas, ainda que não se reduza a estas) nossa educação como um todo, representa a UAB, especialmente, um marco histórico para a educação a distância no País, reforçando assim o sucesso alcançado pela SEED nesses dez anos de vida.

Sem precedentes em nossa história, não há como pensar em outro (2) modelo alternativo para a oferta e gestão de educação superior - alternativo ao modelo de educação presencial, inclusive, a partir da utilização intensiva das tecnologias de informação e comunicação - que não na plena (3) consolidação da rede nacional de educação a distância que, por seu turno, logo remete a uma teia enredada de parceiros de projetos, em intensa articulação, trabalho colaborativo, estreita relação e união de esforços pelo bem comum. Não restando dúvida, portanto, de que o Sistema Universidade Aberta do Brasil, nome mais preciso para representar o processo de descentralização ensejado pelo Projeto UAB, em outras palavras, rede nacional de educação a distância, constitui um passo decisivo para a nossa tão sonhada democratização do acesso à educação superior pública, gratuita e de qualidade. $\mathrm{O}$ que reitera, enfim, a melhoria da qualidade da educação no país e o modelo alternativo para a oferta e gestão de educação superior.

Esse mapeamento do dizer que marca a regularidade discursiva, afetando, de maneira especial, o contexto imediato da sdr 1, é bastante revelador, porém não dá conta plenamente das condições de produção, difusão e circulação que engendram e transcendem tal seqüência. Sobretudo aquelas que permitem determinados enunciados reproduzirem-se ao longo e na plenitude do discurso que norteia a política nacional de educação a distância. As mesmas condições que apontam na direção de um sistema 
de enunciabilidade que, a um só tempo, preside e atravessa desde os discursos relativos à SEED até aqueles que dizem respeito diretamente à $U A B$.

\section{UAB como acontecimento discursivo}

Objetivando desvendar a transcendência do discurso, compreendemos então a sdr 1 como configurando uma seqüência de três acontecimentos discursivos que contribuem para o discurso oficial instaurar uma circularidade. Apesar de nos depararmos, num primeiro momento, com um acontecimento que antecede os demais, não se trata de estabelecer a partir daí uma relação necessariamente linear de causa e efeito, mas de interdependência entre as situações de enunciação que vão se sucedendo e gerando novos acontecimentos discursivos. Dessa forma, concebemos o acontecimento 1 como sendo, principalmente, de produção do discurso, ainda que a sua emergência não seja de base fundadora deste.

Em primeiro lugar, convém ressaltarmos que a sdr 1 não foi escrita aleatoriamente, mas para fazer a abertura da Introdução do T1 “Universidade Aberta do Brasil: democratização do acesso à educação superior pela rede pública de educação a distância". A sequência marca, portanto, a introdução da Introdução do artigo que constitui, por seu turno, o texto inicial da coletânea "Desafios da educação a distância na formação de professores". Na conjuntura em que é produzida, muito mais ainda por representantes diretos da SEED, a abertura de uma coletânea com um artigo a respeito da UAB não poderia significar senão uma ênfase sobre o Sistema como constituindo a interface mais avançada, atualizada e expressiva entre a EAD e a formação de professores. 
Em segundo lugar, marca a produção do T1 uma espécie de comemoração dos dez anos de criação da SEED. Considerando as limitações de espaço de um artigo, coube à sdr 1 fazer uma ligeira retrospectiva a respeito da atuação daquela Secretaria, providencial o bastante para afirmar sua condição de referência não só nacional, como também internacional, na condução de políticas de EAD. Por isso mesmo, textualmente a SEED recebe maior atenção do que a própria $U A B$, objeto discursivo central ao texto no seu conjunto. Isso não significa, porém, uma contradição, pois a utilização de famílias parafrásticas acaba compensando essa eventual assimetria, possibilitando ao discurso sobre a SEED, no mais das vezes, parecer ou se confundir com aquele referente à $\mathrm{UAB}$, como já assinalamos anteriormente.

Em terceiro lugar, como ainda assim toda introdução deve apresentar as finalidades e imprimir desde então objetividade e coerência ao discurso, mais ainda em se tratando de um discurso de natureza político-institucional, a sdr 1 não perde a oportunidade de anunciar a que se propõe o T1: o objetivo de apresentar o Projeto Universidade Aberta do Brasil, suas bases e criação [...], e sua importância na consolidação [do] Sistema Universidade Aberta do Brasil. É certo que a sequência já apresenta algumas pistas indicando condições que induzem à produção do discurso, tais como: utilização intensiva das tecnologias de informação e comunicação no contexto escolar; marco histórico para a educação a distância no País; e democratização do acesso à educação superior pública, gratuita e de qualidade.

Encontramos essas condições melhor sistematizadas, todavia, no segmento que sucede a sdr 1 e que complementa a Introdução do T1. Embora se reporte explicitamente a alguns fatores recentes (condições de produção 
não discursivas) que confluíram para fazer emergir o projeto $\mathrm{UAB}$, aquele segmento refere-se também, mesmo que implicitamente, a fatores ou condições de produção discursivas que dão ensejo à concepção, estruturação e elaboração do T1. É como se, em resposta a tais condições, os autores decidissem produzir não qualquer um, mas um determinado texto: materialização de ambientes e metodologias educacionais inovadores; o arcabouço legal voltado para a área educacional; ações de fomento e projetos voltados para a educação superior a distância, desenvolvidas pelo Ministério da Educação, esferas governamentais e pelos sistemas de ensino.

Essas condições de produção, de certo modo, são complementadas por outros fatores, vinculados ao desmembramento ou a uma nova dimensão do acontecimento discursivo. Nesse sentido, concebemos o acontecimento 2 que envolve a sdr 1 como sendo, particularmente, de ordem da difusão do discurso. A seqüência faz parte de um artigo que não é divulgado em qualquer tempo, lugar ou por intermédio de qualquer mídia. Como encontramos sugerido quase ao seu final, a produção e publicação do T1 se dá em meio ao período de recebimento de propostas, que vai de 21 de dezembro de 2005 a 13 de abril de 2006, para seleção dos pólos de apoio presencial e dos cursos superiores de EAD, conforme estabelece o Edital n ${ }^{\circ} 1$ da SEED, de 16/12/2005.

Sintomático da forte influência que tende a exercer o edital sobre as três esferas governamentais conclamadas a participar do Sistema UAB, como demonstram os fragmentos grifados a seguir, logo no item 1 que trata "Do Objetivo" daquele regulamento já encontramos enunciados, às vezes, na forma de paráfrases, de suma importância 
ao discurso sobre a UAB que são retomados pelo T1, mais precisamente, pela sdr 1:

O presente Edital tem por objetivo fomentar o "Sistema Universidade Aberta do Brasil - UAB", que será resultante da articulação e integração experimental de instituições de ensino superior, Municípios e Estados, nos termos do artigo 81 da Lei de Diretrizes e Bases da Educação, visando a democratização, expansão e interiorização da oferta de ensino superior público e gratuito no País, bem como ao desenvolvimento de projetos de pesquisa e de metodologias inovadoras de ensino, preferencialmente para a área de formação inicial e continuada de professores da educação básica (BRASIL, 2005a, p.39).

Retomando e (re)atualizando um discurso anterior, inscrito em um acontecimento importante como marco regulatório da política nacional de EAD e que tende a se desdobrar em um conjunto de outros acontecimentos discursivos e não discursivos, o T1 é publicado no livro "Desafios da educação a distância na formação de professores", editado pela SEED. Órgão este que não se trata de qualquer instância de enunciação, mas de uma instituição com caráter estratégico para a educação brasileira e que, ao mesmo tempo, serve de referência internacional na área de educação a distância e de tecnologias educacionais. À primeira vista, tendemos a considerar que essa asserção não passa de uma estratégia discursiva, porém precisamos 
compreender que a importância da rubrica SEED não deixa de ser expressiva.

O fato de a publicação ser editada pela SEED, não apenas por causa da possibilidade de uma tiragem significativa, mas também pela representatividade institucional daquela Secretaria, potencializa sua difusão tanto no Brasil como no exterior. Podendo atingir, dessa forma, instituições governamentais nacionais e estrangeiras, sociedades profissionais e científicas e agências de fomento internacionais que demandam informações e "documentos" importantes às deliberações e avaliações relativamente às políticas públicas no campo da educação. São os textos assinados por "autoridades" que costumam servir de base aos financiamentos, convênios e protocolos de cooperação que geram, por extensão, novos acontecimentos discursivos e em cenários mais amplos.

Além de imprimir credibilidade e de ser mais prático e atraente do que projetos e relatórios, o livro na forma de coletânea acaba pressupondo tanto uma polifonia como uma polissemia que se tornam cruciais a sua difusão, notadamente, em tempos pós-modernos ou de sociedade global e do conhecimento. Sob tal conjuntura, produz-se o efeito de sentido de um discurso polêmico, isto é, "aquele em que a reversibilidade se dá sob certas condições e em que o objeto do discurso está presente, mas sob perspectivas particularizantes dadas pelos participantes que procuram lhe dar uma direção, sendo que a polissemia é controlada." (ORLANDI, 1996a, p.154)

$\mathrm{Na}$ "Apresentação" que escreve para "Desafios da educação a distância na formação de professores", logo depois de acentuar que a publicação representa "uma fértil coletânea de artigos de professores e pesquisadores", o Diretor do Departamento de Políticas em EAD/SEED 
e responsável pela criação e implantação do Projeto UAB faz questão de esclarecer:

Para garantir o caráter plural do conjunto do livro, foram convidados autores de variadas áreas de formação superior, mas todos colaboradores do $\mathrm{MEC}$, e que certamente não reúne "consensos", mas constitui-se substrato de variadas vozes que clamam pela consolidação da modalidade de EAD no Brasil, por meio de diálogo entre diferentes visões (algumas antagônicas, ou talvez complementares), visando a construção de um projeto comum, no qual as diferenças integram o patrimônio comum (CHAVES FILHO, 2006).

Consulta à Plataforma Lattes permite-nos constatar que aquela coletânea deixa de referir que boa parte dos seus "colaboradores" tem assento junto ao MEC, entre outras funções, como membros de comissões de especialistas e consultores ad hoc. Nas referências publicadas em nota de rodapé na página inicial de cada artigo, a publicação não esconde, todavia, que os "autores" ocupam posições de sujeito e lugares determinados em instituições nacionais e estrangeiras, cruciais à política de educação a distância. Há professores e pesquisadores vinculados a instituições de ensino superior católicas e estrangeiras (The Open University do Reino Unido), tomadas como referência em EAD; universidades federais, cuja autonomia administrativo-financeira, inclusive dos antigos e novos projetos em EAD, como a UniRede e a UAB, permanece 
em boa parte subordinada ao MEC; e universidades estaduais que, também, recebem incentivos por parte do governo federal (BIELSCHOWSKY, 2006, p.7).

Por isso mesmo, utilizando-se de paráfrases, o próprio discurso oficial assinala, de antemão, existir diferenças entre os autores de "Desafios da educação a distância na formação de professores" que são mais "complementares" do que "antagônicas" (CHAVES FILHO, 2006). No entremeio dos textos que se seguem ao $\mathrm{T}^{15}$, encontramos a princípio enunciados antagônicos que tendem indicar a heterogeneidade dos discursos: De fato, muitas objeções podem ser feitas; nossas dúvidas; cenário pesado demais; muito ainda precisa ser amadurecido; talvez a necessidade de maiores investimentos na formação. Essas objeções, contudo, parecem propositalmente situadas para, logo em seguida, ser dissipadas não só através de marcas discursivas, na forma de conjunções - No entanto, Mas, Entretanto, como também de assertivas que salvaguardam aquilo mesmo que, até então, era questionado Para tanto, Com isso.

Dessa forma, não se faz necessário ao MEC, diretamente, proclamar que suas ações podem resultar em reflexos profundos, soluções surpreendentes, reflexo mais qualitativo pedagogicamente do que quantitativo ou soluções que viabilizem um verdadeiro processo de inclusão social, pois aqueles "autores" já se encarregam de, espontaneamente, o fazer. Para além das supostas "diferenças", o que percebemos ser articulado pelo discurso oficial são os pontos de convergência entre os "colaboradores do MEC",

15 São os seguintes os textos aí referidos: Fagundes (2006), Franco (2006), Garrido e Silva (2006), Schlunzen, Schlunzen Junior e Terçariol (2006). 
cujas "visões" contribuem para "a construção de um projeto comum, no qual as diferenças integram o patrimônio comum" (CHAVES FILHO, 2006), isto é, elas se apagam ou são positivadas em função (também) de um discurso "comum".

O que colocam em evidência os textos ${ }^{16}$ da coletânea "Desafios da educação a distância na formação de professores", antes de tudo, é a regularidade de um discurso sobre as potencialidades da educação a distância que não se conforma apenas que a EAD está evoluindo e buscando sua própria identidade. Amparando-se em metáforas e metonímias, os "colaboradores do MEC" concebem a EAD como uma marca da esperança, uma maravilhosa aventura, uma (res)significação paradigmática, enfim, uma nova dimensão da educação. Além de se tratar de um meio eficiente e eficaz, a EAD para eles representa o desafio contemporâneo de um país continental socializando o que nós temos de melhor, aglutinando e disseminando o conhecimento.

A ênfase na EAD como sinônimo de melhoria da qualidade da educação é parte indispensável desse discurso. A qualificação da educação, a melhor qualificação dos professores, a pretensão de qualificar, seguindo padrões de qualidade, através de cursos de qualidade, é ponto em comum entre aqueles autores. Mais do que antever uma desafiadora $e$ inovadora iniciativa, perpassa entre eles a convicção de que o cenário é múltiplo, múltiplo de mudança, ou melhor, de uma série de mudanças. Incluindo aquelas que representam

16 Desta feita, são os seguintes os textos referidos: Barbeta (2006), Fagundes (2006), Ferretti et al (2006), Franco (2006), Garrido e Silva (2006), Mundim (2006), Neder (2006), Santos (2006), Schlunzen, Schlunzen Junior e Terçariol (2006). 
alternativas de ultrapassar as dimensões geográficas das diferentes regiões, das diversas regiões, sobretudo, das regiões distantes, regiões onde o transporte se apresenta como um fator limitante.

Uma pergunta e uma resposta os unem definitivamente: O que a EAD tem finalmente de tão inovador? Como se todos os "colaboradores do MEC", espontaneamente, resolvessem escrever uma frase parafraseando a mesma resposta, assim respondem eles: soluções alternativas para democratização do ensino; possibilitar ao profissional de baixa renda ter acesso a Internet $e$ aos ambientes virtuais; acesso; acesso à IES; ampliar o acesso ao ensino superior; democratizar o acesso ao ensino superior e pós-superior; acesso a uma boa formação docente. Estariam eles, todavia, a afirmar a mesma coisa: o que a EAD tem de tão inovador é promover a inclusão social e a democratização do conhecimento. Conforme veremos mais adiante, trata-se de um enunciado caro não apenas à política nacional de educação a distância, como também à política educativa e ao próprio Estado brasileiro contemporâneo.

O discurso dos "colaboradores do MEC", por sinal, não assume declaradamente, mas também não nega que se inscreva em uma formação discursiva dominante. Antes, acima e atravessando a percepção da comunidade acadêmica - ou seja, um sujeito/comunidade discursiva (MAINGUENEAU, 1993), encontramos o posicionamento do governo (e, mais ainda, da UNESCO e BANCO MUNDIAL), um sujeito inscrito na esfera do sujeito universal (PÊCHEUX, 1988) que, ao regular a EAD no ensino superior, tende impor ordem ao discurso (FOUCAULT, 2004) em torno da educação a distância no âmbito da universidade. Uma vez que o governo detectou nas TICs, especialmente na Educação a distância (EAD), uma alternativa 
para resolver os problemas estruturais, parece não restar à comunidade acadêmica senão enxergar a Educação a Distância como uma alternativa para as atuais necessidades de capacitação docente.

Retomando o T1, perceberemos pois que esse ordenamento não se dá de forma automática nem homogênea, mas depende, fundamentalmente, de uma prática discursiva, de cujas bases participam tanto as condições de produção e difusão como as condições de circulação do discurso. O enunciado abertos ao diálogo que ganha ênfase na sdr 1 nos chama atenção para um fato importante: a seqüência possui uma materialidade lingüística, porém não se resume a um texto em si ou a um artigo que faz parte, meramente, de um produto-coletânea. O discurso aí pronunciado constitui, por excelência, um processo que se configura, seguindo nosso raciocínio, através do acontecimento 3 que afeta aquela sequência, desta feita, no campo da circulação dos discursos, atualizando-a por intermédio de outros acontecimentos discursivos, tão ou mais importantes.

Além de sua produção já constituir uma ação que mobiliza uma série de posições de sujeito (patrocinadores, autores, editores etc.), um tempo e um lugar em torno de um discurso, o texto político necessita, muitas vezes, forjar um novo acontecimento discursivo, sob pena de determinadas deliberações acabarem sendo ignoradas. Como nos ensina Courtine (1981), a produção, a difusão e a circulação dos discursos na instância do acontecimento são indissociáveis, evidenciando que a produção de uma seqüência discursiva inscreve-se em uma rede de disseminação dos enunciados que regula a circulação das formulações no interior de uma formação discursiva e estabelece a relação desta com o seu exterior: "el trabajo de una FD como 
memoria discursiva deberá, necesariamente, tomar en cuenta las condiciones de difusión y circulación del archivo."

Por isso mesmo, graças ao seu caráter ao mesmo tempo político e público, os setores de governo buscam estabelecer relações com organizações não governamentais e a sociedade civil que representam, muitas vezes, interlocutores essenciais à repercussão e legitimação do discurso oficial. O lançamento da coletânea "Desafios da educação a distância na formação de professores" acaba sendo feito durante o IV Congresso Brasileiro de Ensino Superior a Distância (IV Esud), oportunidade ímpar para a difusão e circulação de um discurso que atravessa a política de EAD. Até porque, conforme assinala a "Apresentação" da coletânea, a publicação representa uma das "estratégias de colaboração" da SEED com a sociedade, "em momento do cenário nacional bastante propício para o debate sobre a questão da qualidade educacional e da formação de professores." (CHAVES FILHO, 2006)

Realizado em Brasília entre 16 e 19 de maio de 2006, o IV Esud coincide com a fase de análise dos projetos concorrentes ao Edital n ${ }^{\circ} 1$ da SEED, de 16/12/2005, para participação no Sistema UAB. Por um lado, marca o período a expectativa entre os Estados, municípios e universidades em atender aos critérios que uma comissão de especialistas levará em conta para a seleção das propostas de cursos e pólos de apoio presencial. Por outro, perpassa aquele momento a ênfase por parte da SEED/MEC em ampliar suas "estratégias de colaboração" com aquelas instâncias e "toda sociedade brasileira", com vistas especialmente a consolidar e legitimar o Projeto UAB.

O que implica voltar a atenção para o IV Esud que, logo em seus objetivos, mediante paráfrases, reitera a ênfase na formação continuada do professor, na inovação 
tecnológica e metodológica, na integração das instâncias atuantes em EAD e na democratização e qualificação do ensino superior público. $\mathrm{O}$ evento é promovido pelo Centro de Educação a Distância (CEAD) da Universidade de Brasília, em parceria com a SEED e a Universidade Virtual Pública do Brasil (UniRede) que, até a emergência do Sistema UAB, consiste na instância privilegiada de enunciação e execução de políticas na área de EAD (ASSOCIAÇÃO, 2007).

Além da presidente da UniRede e do diretor do CEAD, o IV Esud tem forte presença de representantes do Ministério da Educação. À cerimônia de abertura, no dia 16 de maio de 2006, comparecem o presidente da Capes, o secretário de Educação a Distância e o próprio ministro da Educação. Na ocasião, o ministro faz questão de reconhecer o comprometimento das instituições promotoras do evento (CEAD/UnB, UniRede e SEED) com uma "educação de qualidade". Segundo ele, em consequência da expansão da EAD no país: "O Brasil começa a olhar com outros olhos para a educação a distância." Marca esse avanço, conforme ainda o ministro, o fato de que: “Em 2005, a Seed foi executora de programas e projetos que mudaram os rumos da educação a distância no país [incluindo a UAB]." (BRASIL, 2006d)

Apesar de não economizar em metáforas e metonímias, o ministro não deixa de utilizar paráfrases que retomam enunciados importantes ao T1, como também que atualizam o próprio "Prefácio" assinado pelo mesmo na coletânea "Desafios da educação a distância na formação de professores", lançada também na abertura do IV Esud. No "Prefácio", a ênfase do ministro recai sobre o fato de que, no "contexto da melhoria da qualidade da educação no Brasil", a "Secretaria de Educação a Distância do 
Ministério da Educação vem nos brindar, a toda sociedade brasileira", com uma coletânea que aborda "importantes trabalhos" na área de EAD. Destacando o "Programa Universidade Aberta do Brasil", reitera o ministro que a UAB resulta de "estreita colaboração" entre governo, universidade e sociedade civil "e que será um divisor de águas no tocante à solução definitiva do problema da carência de professores na educação básica, bem como da democratização do acesso dos jovens à educação superior pública, gratuita e de qualidade." (HADDAD, 2006, p.8)

Momentos antes do lançamento da coletânea, em Conferência Magna proferida sobre o tema "Educação no ciberespaço: novas e velhas pedagogias com o uso das tecnologias digitais $\square$, o líder do Grupo de Pesquisa Sociedade do Conhecimento na Faculdade de Educação da Universidade Nacional de Educação a Distância de Madrid (Uned) havia feito "críticas aos entusiastas que acreditam na EaD como solução dos problemas do sistema educacional brasileiro." (ASSOCIAÇÃO, 2006) Em sua palestra "Políticas públicas para expansão do ensino superior a distância", proferida no segundo dia do IV Esud, o secretário da SEED acentua porém que o Brasil acompanha uma tendência em nível global, em que a utilização de mídias na educação já se tornara uma realidade tal que exigia de tais políticas garantirem a sua pronta implementação: “Não se pode mais pensar a educação dissociada das novas tecnologias de informação e comunicação" (BRASIL, 2006h).

Sua afirmação não deixa de aludir à $6^{\mathrm{a}}$ Conferencia Internacional de la Educación y la Formación Basada en las Tecnologias que, de 17 até 19 de maio de 2006, realiza-se em Madrid, com apoio entre outros do governo brasileiro. Organizada pela empresa alemã ICWE (Internacional 
Conferences, Workshops and Exhibitions) (ONLINE, 2006, p.3) e mais conhecida como Online Educa Madrid, "punto de encuentro entre Europa y Latinoamérica", a conferência homenageia o MEC, com a inclusão do secretário da SEED no Comitê de Honra. Segundo ele, o evento representa "o espaço ideal para se conhecer as últimas tendências e inovações da educação virtual e de realizar negócios." (BRASIL, 2006g) Além de reafirmar a importância das "inovações" para a educação, retoma o secretário enunciados que enfatizam as instâncias de interação e articulação como "espaço ideal" para a circulação do discurso (acontecimentos discursivos), assim como para a realização de negócios que podem envolver desde contratos comerciais até convênios institucionais e governamentais (acontecimentos não discursivos).

O representante da SEED, por sinal, volta da Espanha mais convicto em relação aos avanços da EAD no país: "pude perceber o quanto o Brasil é reconhecido como tendo um grande potencial em EAD. Haja vista o fato de terem me chamado para fazer palestra de encerramento. $\mathrm{O}$ que tem de interessante no Brasil é que aqui a EAD nasce sem nenhum preconceito." (BRASIL, 2006a) Evocando o Brasil como referência internacional, ele (re)atualiza o discurso do sucesso alcançado pela SEED na condução da política de EAD e adiciona uma outra idéia que se refere não apenas à ausência de preconceito na aplicação da educação a distância, mas que reforça a sua ausência no campo discursivo e, ao mesmo tempo, inibe a emergência de contradiscursos.

A propósito, poucos dias depois de encerrados o IV ESUD e o Online Educa Madrid, entre 27 e 28 de maio de 2006, o CEAD/UnB promove o primeiro encontro presencial de sua Especialização em Educação a Distância, 
em Brasília, com aula inaugural proferida pelo secretário da SEED. Na ocasião, o diretor do CEAD ressalta: "no momento em que o Governo Federal dá grande impulso a essa modalidade de ensino o curso vem com o objetivo de colaborar na formação de competências para esta modalidade de ensino no Brasil" (BRASIL, 2006e).

Pouco menos de um mês depois, em 19 de junho de 2006, é a vez da própria SEED/MEC, em parceria com a Universidade Federal do Rio Grande Sul (UFRGS) e a Pontifícia Universidade Católica do Rio de Janeiro (PUC-RJ), lançar o Curso de Especialização a Distância em Tecnologias na Educação. Contando com apoio do ambiente colaborativo do e-ProInfo, o curso destina-se a capacitar 1.700 professores da rede pública para atuarem como "multiplicadores" nos Núcleos de Educação Tecnológica (NTEs) das capitais brasileiras. A especialização representa a $35^{\mathrm{a}}$ formação de professores promovida pela SEED (BRASIL, 2006b), cujas ações visam "investir fortemente no uso das Tecnologias de Informação e Comunicação (TIC) na educação pública brasileira, com a perspectiva de elevar o seu padrão de qualidade." (BRASIL, 2006f)

Conforme tivemos oportunidade de demonstrar mais amplamente, mediante pesquisa sobre o discurso da industrialização do ensino em importantes eventos realizados no Brasil, entre meados de 2006 e meados de 2007 (COSTA, 2008, p.178-195), o discurso oficial dissemina-se portanto através de acontecimentos discursivos que criam uma circularidade, ou seja, uma relação contínua e permanente entre a produção de um texto e a sua difusão e circulação enquanto discurso. Isso nos permite compreender por que alguns enunciados têm o privilégio de manter uma regularidade, criando as bases necessárias para a continuidade, 
legitimidade e credibilidade do discurso. Ao realizar o V Esud, conjuntamente ao $6^{\circ}$ Seminário Nacional ABED de Educação a Distância, em Gramado-RS, entre 22 e 25 de abril de 2008, a UniRede parece aproximar, cada vez mais, seus objetivos daqueles que movem a iniciativa privada, consolidando o evento "como o espaço para discussão do estado da arte dos aspectos de gestão, concepção didática e tecnológica relacionada com a educação superior a distância." (ASSOCIAÇÃO; UNIVERSIDADE, 2008)

Como continuidade e descontinuidade são faces de um mesmo processo discursivo, ao privilegiarmos a primeira em nossas análises, estamos considerando que alguns enunciados com importância circunscrita a uma determinada situação de enunciação não guardam a relevância necessária para extrapolar tal circunstância e se (re)apresentar em novos acontecimentos discursivos, cedendo lugar a outros capazes de se repetir mais indefinida e amplamente. Algo que acontece, de modo especial, aos fragmentos de discurso que se reportam à industrialização do ensino na sdr 1 e, extensivamente, no T1.

\section{Fragmentos da industrialização do ensino na UAB}

Como discurso algum é transparente, muitas vezes escapando ao próprio sujeito falante, faltou aos locutores do T1 (melhor dizendo, estava fora de suas competências e propósitos) dizerem aquilo que ficou opaco: o discurso em torno da $\mathrm{UAB}$, na realidade, parte e converge na direção de reiterar o discurso da industrialização do ensino. Essa opacidade, é claro, faz parte do funcionamento discursivo, sendo imanente a este, muito mais ainda, em se tratando de um discurso oficial e de tipo autoritário, 
comprometido com uma dada formação discursiva e ideológica.

Para alcançarmos tal sistema de enunciabilidade, precisamos evidenciar os fragmentos da industrialização do ensino presentes no discurso da política nacional de EAD. Buscaremos elucidar, portanto, a presença e predominância desses fragmentos na sdr 1, ao longo do T1 e, complementarmente, no conjunto do corpus de análise. De antemão, salientamos que essa ocorrência, em geral, não se apresenta de forma evidente, cabendo-nos efetuar a tarefa pretensiosa de deixar transparecer, mediante as relações interdiscursivas, o principal efeito de sentido que visa produzir o discurso oficial - a reprodução e legitimação do discurso da industrialização do ensino.

Em outras palavras, pretendemos desvendar aquilo que o discurso em torno da política de EAD teima em esconder, relega ao esquecimento, ou mesmo, faz questão de passar despercebido que é a recorrência, permanente e sistemática, às seguintes marcas ou propriedades discursivas: racionalização, divisão de trabalho, mecanização, linha de montagem, produção de massa, trabalho preparatório, planejamento, organização, mudança de função e especialização, métodos de controle científicos, formalização, padronização, objetivação, concentração e centralização.

\section{A racionalização do Sistema}

Embora configure fundamento de todo e qualquer processo de industrialização, podendo se traduzir em uma série de outras de suas condições estruturais, a racionalização é uma das primeiras características da industrialização do ensino que encontramos evocada na sdr 1 . De 
início, convém ressaltarmos que o enunciado atuado transversalmente tende referir muito mais do que apenas ações e gestões que a SEED tem efetuado junto às demais secretarias e órgãos do MEC. O enunciado faz alusão, sobremaneira, a uma performance que tem como base os princípios racionais de uma atuação eficiente e eficaz. Não fosse assim, do mesmo modo que certamente empregou a política do silêncio (ORLANDI, 1997) a outros objetos, o sujeito do discurso teria relegado aquela atuação ao esquecimento ${ }^{17}$.

Empregarmos a racionalização é importante, ainda, para aproximarmos dois outros fragmentos que, em princípio, dizem respeito a referentes distintos: intensa articulação e utilização intensiva. Mesmo considerando que o primeiro esteja associado, de forma direta e imediata, a instituições (SEED/MEC e sistemas de ensino) e o segundo ao uso das TICs no contexto escolar, chama-nos a atenção o fato de que os adjetivos usados para dimensionar os processos de articulação e de utilização são, praticamente, sinônimos. Melhor ainda, intensa e intensiva remontam, a um só tempo, atividades realizadas de forma austera, em curto prazo e numa dinâmica a mais intensificada possível, representando pois adotar critérios de máxima racionalização daqueles processos.

17 Em seu "Prefácio" à coletânea que inclui o T1, o ministro da Educação já faz a seguinte observação: "Quero enaltecer o importante papel 'transversal' da Secretaria de Educação a Distância, que tem sido a ponte simbólica entre os diversos órgãos deste ministério, na consolidação da visão sistêmica da educação, proporcionando os benefícios do aporte de tecnologias de informação e comunicação à educação, desde a produção do conhecimento até a extensão dos seus benefícios à população." (HADDAD, 2006, p.9) 
Semelhantemente, não observamos à primeira vista qualquer outra relação que não seja objetiva entre os constituintes do enunciado inovações tecnológicas e metodológicas para a melhoria da qualidade da educação no país. Além do mais, um pouco mais adiante, o enunciado é retomado através do verbo inovar que produz aquele mesmo efeito de sentido, só que no âmbito específico da educação superior. Examinados do ponto de vista discursivo, esses fragmentos fazem alusão a elementos cruciais aos processos de racionalização que são as relações de causa e efeito, custo e benefício. Notadamente, quando consideramos que as inovações científico-tecnológicas visam, de forma pragmática, otimizar os resultados da produção de bens e serviços, a exemplo da qualidade dos sistemas de ensino superior.

Nessa mesma linha, encontramos o enunciado sucesso alcançado pela SEED. Ao invés apenas de registrar um acontecimento exitoso na trajetória daquela instituição, o enunciado reitera a importância da relação custo-benefício na atuação da administração pública que, dessa forma, deve seguir a racionalidade da iniciativa privada, para a qual todo esforço ou investimento precisa lograr um excelente resultado. $\mathrm{O}$ fragmento destacado a seguir, por sinal, sintetiza melhor ainda como essa racionalização dos meios e fins pontua a sdr 1 :

Hoje, considerando-se o espectro de projetos e programas por ela [SEED] desenvolvidos, desde a regulamentação para educação a distância, passando pelos programas de formação, o desenvolvimento de conteúdos multimídia, e com forte incentivo à pesquisa para o setor, podemos afirmar seu caráter estratégico para a educação brasileira. 
A alusão aos princípios da racionalização, todavia, não se resume à sdr 1, afetando o T1 como um todo. Um conjunto de enunciados dispersos e difusos marca essa continuidade, desde o domínio produtivo do conhecimento que confere ênfase a um princípio essencial à racionalidade - a produtividade - até a adoção de medidas com base nos princípios da eficiência e da eficácia: forte potencial de solução para esse quadro; ações e projetos que buscam potencializar as políticas públicas educacionais; essas ações poderão multiplicar-se em número, além de melhorar em qualidade.

Os princípios da inovação e do custo-benefício, também, são retomados. O primeiro através dos enunciados constantes avanços tecnológicos e materialização de ambientes e metodologias educacionais inovadores e, o segundo, mediante os seguintes fragmentos que mantêm a preocupação em relacionar ações e resultados: extensão de seus benefícios à população e $O$ nível de formação dos docentes guarda forte relação com o desempenho dos estudantes. Mais sintomáticos dessa relação, ainda, demonstram ser os enunciados custo estimado por aluno; estimativa de custo para o material impresso e $O$ custo dos alunos com vínculos com as empresas estatais serão cobertos pelas mesmas. O que indica ser fundamental às empresas envolvidas estabelecer minuciosamente a implicação do custo-benefício da formação de cada aluno na $\mathrm{UAB}$, sobretudo quando consideramos que elas são obrigadas a prestar contas de seus investimentos.

A ênfase sobre a racionalização não se esgota aí, pelo contrário. Encontramos alguns enunciados no T1 que se mostram ainda mais incisivos, a ponto de recorrerem à seguinte analogia: Pretende-se que o sistema de biblioteca seja idealizado como uma Unidade de Informação. Como veremos adiante ao analisarmos os fragmentos relativos à mecanização, concentração e centralização, a descrição 
daquela unidade não difere em nada, praticamente, de qualquer outro tipo de unidade de produção, em moldes industriais ou racionais. Tanto é que, na sua essência, o projeto UAB caracteriza-se pela reafirmação do caráter estratégico desse nível educacional, do desenvolvimento científico e da inovação tecnológica para o crescimento sustentado do país, além de estabelecer metas e ações para a promoção da educação inclusiva e cidadã. Invoca-se pela reafirmação, portanto, o primado da educação superior, do desenvolvimento científico e da inovação tecnológica (algo caro ao projeto de racionalidade da sociedade industrial) como condição para o crescimento sustentado do país e a educação inclusiva e cidadã, fenômenos por sua vez que seriam típicos a uma sociedade pós-industrial.

O conjunto dos princípios da racionalização vai se apresentar junto ao T1 de forma mais articulada, entretanto, na seguinte série consecutiva de fragmentos: ações que vêm ocorrendo de maneira individualizada e não sistemática, com sobreposição de esforços e recursos; O estabelecimento de parcerias nacionais seria extremamente proficuo, pois possibilitaria a troca de experiências, o compartilhamento de instalações tecnológicas, a elaboração conjunta de ferramentas de comunicação e de material didático, economizando tempo e investimento; com esse princípio de trabalho conjunto, as universidades e as Empresas Estatais estarão favorecendo o desenvolvimento científico, tecnológico e social do país.

Antes de tudo, o sujeito do discurso chama atenção de que estariam sendo desenvolvidas iniciativas de forma irracional que, no fundo, contradizem a lógica do Estado contemporâneo: ações que vêm ocorrendo de maneira individualizada e não sistemática, com sobreposição de esforços e recursos. Razão que torna imprescindível o estabelecimento de parcerias nacionais (amplas e sistemáticas) que seria - o 
verbo no futuro do pretérito não indica hipótese, incerteza ou irrealidade, mas uma estratégia discursiva utilizada para não impor uma idéia de maneira imediata - extremamente profícuo (o que retoma produtividade, eficiência, eficácia) para imprimir racionalidade àquele processo assistemático.

Mesmo porque a troca de experiências, o compartilhamento de instalações tecnológicas, a elaboração conjunta de ferramentas de comunicação e de material didático decerto possibilitaria (forma verbal empregada para produzir o mesmo efeito de sentido do caso anterior) dotar aquelas ações de princípios racionais por excelência, economizando tempo e investimento. Não restando dúvida, portanto, de que o princípio de trabalho conjunto, baseado na justaposição (e não na sobreposição) de esforços e recursos e na economia de insumos conduz ao desenvolvimento científico, tecnológico e social do país, aos marcos, pois, de um país industrializado.

Divisão de trabalho e especialização burocrático-profissional

Paralelamente aos vestígios da racionalização, encontramos na sdr 1 fragmentos de três outras características estruturais da industrialização do ensino - divisão de trabalho, linha de montagem e mudança de função/ especialização. Nossa análise das três condições conjuntamente parte do pressuposto de que o processo de produção em EAD, assim como acontece à produção industrial, mobiliza instâncias e profissionais de diversas origens e competências.

A simples referência a esses agentes ao longo da seqüência oferece-nos uma boa idéia de como o sistema de produção que envolve a UAB é amplo e complexo: Secretaria de Educação a Distância (SEED); Ministério da 
Educação; demais secretarias e órgãos do MEC; sistemas de ensino; contexto escolar; programas TV Escola e Proinfo; espectro de projetos e programas; programas de formação; parceiros de projetos; instituições de educação superior; Secretarias Estaduais de Educação; Projeto Universidade Aberta do Brasil; novas redes de colaboração; novos e diferenciados partícipes; Fórum das Estatais pela Educação; rede nacional de educação a distância; Sistema Universidade Aberta do Brasil; Estados e Municípios; três esferas governamentais.

Essa relação generalizada, porém, não nos permite precisar os vínculos e as competências institucionais e profissionais de cada membro junto à UAB. Algumas pistas nessa direção, de todo modo, são fornecidas pela sdr 1, destacando-se inicialmente aquelas que reiteram o nome de determinadas instituições: Secretaria de Educação a Distância (SEED), demais secretarias e órgãos do MEC, instituições de educação superior, Secretarias Estaduais de Educação - evocadas, novamente, através dos Estados e Municípios - e Sistema Universidade Aberta do Brasil, reiterado como Projeto Universidade Aberta do Brasil e rede nacional de educação a distância. $\mathrm{O}$ fragmento que reproduzimos a seguir representa um bom indício da ênfase sobre essas instâncias: "Grande parte do sucesso alcançado pela SEED nesses dez anos de vida, se deve à estratégia de trabalho colaborativo com os parceiros de projetos, em destaque as instituições de educação superior, as Secretarias Estaduais de Educação e as demais Secretarias do MEC".

Além de sua maior ocorrência, acontece que o discurso em torno dessas instituições é pontuado por uma série de alusões que nos permitem compreender a participação de cada uma delas no conjunto do processo. O papel da $S E E D$ é logo definido e destacado, graças não somente ao seu vínculo institucional mais amplo - Ministério da 
Educação, o que remonta à instância do Governo Federal responsável pela política educativa brasileira, como também por força de sua competência específica - Secretaria de Educação a Distância - e distinta das demais secretarias e órgãos do MEC.

Junto a estas, todavia, a SEED tem atuado transversalmente, evocando uma capacidade extremada de interlocução com uma série de órgãos ligados diretamente ao MEC e a cinco outras secretarias que compõem a estrutura do Ministério (SEB, Sesu, Setec, SEESP e Secad). O que estende a influência da SEED desde o ensino básico e superior até a educação profissional, tecnológica, especial e continuada, incluindo a alfabetização e diversidade. A Secretaria tem atuado, além disso, em intensa articulação com os sistemas de ensino, o que produz um novo efeito de sentido, ampliando seu raio de influência até os limites da rede pública federal, estadual e municipal de educação.

Após uma década de experiências, sua estratégia de trabalho colaborativo com os parceiros de projetos é retomada de forma exemplar, a ponto de ter sido responsável por Grande parte do sucesso alcançado pela SEED, tanto no país quanto lá fora. No Brasil, destacando-se por seu caráter estratégico para a educação brasileira; no exterior, na condição de referência internacional na área de educação a distância e de tecnologias educacionais. Cabendo-lhe, pois, como requer qualquer organização que atua no mercado ou em outro ambiente social, também fazer o marketing de suas ações que se estende ao MEC e ao Governo Federal que representa. No conjunto, desenvolve a SEED um espectro de projetos e programas, desde a regulamentação para educação a distância, passando pelos programas de formação, o desenvolvimento de conteúdos multimídia, e com forte incentivo à pesquisa para o setor, que lhe permitem assumir a função privilegiada de conduzir a política nacional de EAD. 
Depois da SEED, observamos que é o próprio Sistema Universidade Aberta do Brasil que tem seu lugar determinado em meio à sdr 1 . Mesmo ainda mencionado como Projeto, a UAB assume o papel de dispositivo por meio do qual será possível inovar, o que remete a uma capacidade inata de promover a utilização intensiva e racional das inovações tecnológicas e metodológicas; assim como propor modelo alternativo para a oferta e gestão de educação superior, tendo como referência a educação a distância. Cabe à UAB como Projeto, ainda, favorecer o estabelecimento de novas redes de colaboração, com novos e diferenciados partícipes, renovando e ampliando de forma substancial o leque dos antigos parceiros de projetos da SEED.

Além de sua importância na consolidação da rede nacional de educação a distância, numa alusão às instituições de educação superior públicas, compete à $\mathrm{UAB}$ enquanto Sistema atuar cristalizando a união de esforços das três esferas governamentais, consolidando e maximizando as suas possibilidades de articulação. De sorte que, sobretudo quando consideramos que tem em vista a democratização do acesso à educação superior pública, gratuita e de qualidade, percebemos que a UAB exerce uma função central, na mesma linha da referência internacional e do caráter estratégico associados à SEED. Ao incorporar o papel de marco histórico para a educação a distância no País, a UAB passa a representar a instância, por excelência, capaz de atualizar a educação superior pública brasileira aos avanços representados pelo modelo emergente da universidade aberta, virtual e global.

As instituições de educação superior, as Secretarias Estaduais de Educação e as demais Secretarias do MEC, apesar de também destacadas na sdr 1, são aludidas como ocupando uma espécie de lugar secundário no processo de 
produção envolvendo o Sistema UAB: Ele será formado pelas instituições federais de educação superior, em estreita relação com os Estados e Municípios, cristalizando a união de esforços das três esferas governamentais. Somente analisando o T1 no seu conjunto é que vamos perceber como os lugares dessas instâncias encontram-se bem definidos, assim como as posições ocupadas pelas demais instituições e agentes evocados pelo sujeito do discurso que se vê afetado, sensivelmente, pela formação discursiva responsável por suas reiteradas menções à divisão de trabalho, linha de montagem e mudança de função/especialização.

O próprio T1 em si já encerra uma organização formal atravessada pelo processo de produção industrial. Começa pelo fato de que é produzido por um grupo de locutores, cada qual representando uma instância de competência da SEED essencial ao discurso sobre a UAB: a Coordenação-Geral de Articulação Institucional, a quem caberia, a princípio, a ênfase sobre as parcerias; o Departamento de Políticas em EAD, ao qual competiria referenciar os projetos e programas; a própria Secretaria, à qual estaria atribuída a "palavra final" em torno da $\mathrm{UAB}$; e, por último, representado inclusive através desses agentes, o MEC, responsável pelas menções histórico-estruturais à EAD, educação e política educativa em geral. Um fragmento significativo dessa divisão de trabalho é o seguinte enunciado, constante da legenda que subscreve cada uma das três tabelas sobre funções docentes, apresentadas no entremeio do texto: Tabela elaborada por $M E C /$ SEED/DPEAD/CGAI.

Essa instância de produção, até por força da complexidade e riqueza intrínsecas à temática em questão (como já salientado na sdr 1), acaba mobilizando outras instâncias produtoras de discurso, formando com elas praticamente 
uma cadeia produtiva, sob a égide da formação discursiva aí predominante. Na contextualização que elabora, objetivando apresentar Alguns dados sobre oferta e atendimento na educação superior brasileira e Alguns dados sobre docentes e formação docente no Brasil, o sujeito do discurso logo se apóia em uma série de outras instâncias estratégicas ao processo de enunciação: Constituição Federal, Lei $n^{0}$ 9.394/96 - Lei de Diretrizes e Bases da Educação Brasileira e Plano Nacional de Educação, criado pela Lei 10.271/01, referenciando um marco regulatório, a princípio, originário do Congresso Nacional; IBGE/PNAD/200418, INEP/Censo Escolar 2005, www.edudatabrasil.inep.gov.br (em alusão ao Sistema de Estatísticas Educacionais-Edudatabrasil), e INEP/SAEB (em alusão ao Sistema Nacional de Avaliação da Educação Básica), evocando dessa forma bases de dados vinculadas ao próprio Governo Federal.

Avançando o texto, ao elaborar tópico sobre O Projeto UAB no Fórum das Estatais pela Educação, o sujeito do discurso mobiliza duas outras instâncias importantes - o Fórum e, novamente, o Projeto Universidade Aberta do Brasil. Como sugerem as Referências Bibliográficas ao final do T1, as alusões ao primeiro apóiam-se no Diálogo para a cidadania e inclusão - Texto-Base, documento originário que lança as bases daquela instância. As menções ao segundo têm como base, por sua vez, o próprio Projeto $U A B$, cuja produção capitaneada pela SEED representa a convergência de esforços das instituições participantes do Fórum, em especial, o Governo Federal, empresas estatais e a Associação Nacional

18 Levando em conta que a mesma Pesquisa Nacional por Amostra de Domicílios é reiterada como Brasil 2002 - Pnad/ IBGE e Brasil 2002 - PNAD/IBGE, consideramos esta última como prevalecente. 
dos Dirigentes das Instituições Federais de Ensino Superior - ANDIFES.

Os tópicos restantes do T1 apóiam-se em editais públicos e, mais uma vez, na SEED. No que se refere ao tópico O Projeto-Piloto com o Banco do Brasil, sua produção nos é sugerida a partir do seguinte enunciado que antecede toda uma descrição sobre aquele projeto: Os editais para os processos seletivos foram divulgados em rede nacional em 17 de abril de 2005. Caso semelhante acontece ao tópico O Edital de Convocação, cuja produção teria como base edital público, lançado em 20 de dezembro de 2005.

Além de ser da competência da SEED elaborar esses editais por força de prerrogativa institucional que, por sua vez, evocam marcos regulatórios mais abrangentes, o texto é finalizado através do tópico Projetos encaminhados para avaliação que tem origem naquela Secretaria, como demonstra o seguinte fragmento: Até a data limite de 13 de abril de 2006, a SEED havia contabilizado. Completando-se, dessa forma, o próprio ciclo de produção do discurso em torno da UAB que privilegia a SEED, porém reúne outras instâncias de enunciação invocadas, direta e indiretamente, pelo sujeito do discurso.

Cabe ao T1, por isso mesmo, ampliar o quadro das instâncias vinculadas à $\mathrm{UAB}$, além daquelas já referidas e retomadas em forma de paráfrase, através de fragmentos, tais como: ambientes e metodologias educacionais inovadores; IBGE; INEP; setor público; políticas públicas educacionais; sala de aula; nível/modalidade de ensino; Creche; Pré-Escola; educação básica; Ensino Fundamental; Ensino Médio; modalidade Educação de Jovens e Adultos (EJA); Educação Especial; Educação Profissional e Tecnológica; Região Norte; Região Nordeste; Centro-Oeste; Região Sudeste; Região Sul; toda a sociedade brasileira. Em meio à dispersão e difusão dessas 
instâncias é que vamos encontrar, em particular, as demais Secretarias do MEC, as Secretarias Estaduais de Educação e as instituições de educação superior assumindo lugares determinados no Sistema $U A B$.

Muito embora não faça mais nenhuma referência direta às demais Secretarias do $M E C$, o sujeito do discurso retoma-as no T1, principalmente, por ocasião dos tópicos Alguns dados sobre oferta e atendimento na educação superior brasileira e Alguns dados sobre docentes e formação docente no Brasil. A ênfase aí dispensada aos baixos índices de acesso à educação superior e de formação dos professores acaba fazendo alusão aos diversos níveis e modalidades do sistema educacional, cuja competência, em primeira instância, cabe às secretarias vinculadas ao MEC, responsáveis desde a Creche, Pré-Escola, Ensino Fundamental, Médio e superior até a Educação de Jovens e Adultos (EJA), Especial, Profissional e Tecnológica.

Conforme nos evidencia o fragmento destacado a seguir, como a problemática afeta, sensivelmente, a alçada da SEED (Educação a Distância), o desenho proposto para o Sistema Universidade Aberta do Brasil, apresenta forte potencial de solução para esse quadro, pois reunirá, em um grande movimento nacional, as Instituições de Educação superior e as demais esferas governamentais [aí, também, aludidas as demais Secretarias do MEC], em torno da questão: democratização da educação superior e formação inicial e continuada de professores.

O papel das Secretarias Estaduais de Educação é definido, por sua vez, a partir das menções dirigidas aos estados $e$ municípios. Ao longo do T1, encontramos uma série de fragmentos que nos permitem ir recompondo suas responsabilidades: sistemas de ensino; educação básica; cenário nacional de assimetrias educacionais; regiões distantes; mais distantes rincões do nosso país; centros regionais de desenvolvimento; 
pólos regionais; esferas estaduais e municipais; cada unidade da federação participante; dirigentes de Municípios, de Estados $e$ do Distrito Federal. O lugar reservado a essas instâncias junto ao Sistema $U A B$, enfim, é salientado através do seguinte enunciado, constante do último parágrafo do texto: quatrocentos e nove municípios proponentes, totalizando quatrocentos e quatorze projetos de pólos de apoio presencial, em todas as vinte e sete unidades da federação, cabendo-lhes, em síntese, além de propor, colocar em pleno funcionamento os pólos aprovados.

O enunciado é sucedido por um fragmento que nos oferece uma boa idéia, desta feita, das atribuições concernentes às IFES: Em relação ao projetos de cursos superiores na modalidade a distância, foram contabilizadas trinta e sete universidades federais e onze centros federais de educação tecnológica (Cefets) proponentes, com forte concentração da oferta nas licenciaturas, cabendo-lhes, pois, além de propor, colocar em pleno funcionamento os cursos selecionados. Antes disso, observamos desde a Introdução do T1 uma variedade de fragmentos que, mesmo às vezes dispersos ou difusos, reforçam as alusões ao papel destinado pela UAB às instituições públicas de educação superior, tais como: capilarização e interiorização da oferta; trabalho de gestão da educação superior na dinâmica de rede; formação superior inicial e continuada; habilitação para exercer a docência; e universidade pública e gratuita.

Além das Secretarias do MEC, Secretarias Estaduais e IES, o Fórum das Estatais pela Educação constitui a outra instância importante que tem seu papel evocado no T1. Como acontece à sdr 1, as menções feitas pelo sujeito do discurso ao Fórum não são tão extensas, mas se apresentam bastante enfáticas, como por exemplo: espaço de diálogo e interlocução entre Ministério da Educação, Governo Federal, 
estatais brasileiras e toda a sociedade brasileira; instâncias propositivas de ações e projetos que buscam potencializar as politicas públicas educacionais promovidas pelo Governo Federal; fértil parceria entre Empresas Estatais e universidades públicas. No fundo, conforme demonstram os fragmentos que reunimos a seguir considerando sua complementaridade discursiva, o conjunto das instituições participantes do Fórum das Estatais da Educação [se o "da" não indicar um erro de digitação, teríamos aí um efeito de sentido restringindo o Fórum às estatais da área de educação] propõe a criação do Sistema $U A B$, representando a convergência de esforços das instituições participantes do Fórum e, em particular, elegendo as empresas estatais como parceiras potenciais no compartilhamento colaborativo de experiências em EAD.

A racionalidade da cadeia produtiva que envolve a UAB manifesta-se de modo mais contundente, ainda, quando examinamos a série de fragmentos marcada por um processo de divisão de trabalho, linha de montagem e, principalmente, mudança de função e especialização dos agentes envolvidos, destacando-se os seguintes: 0 sistema de tutoria consistirá de duas modalidades de tutoria: tutoria local e a distância; os estudantes contarão com o acompanhamento de um coordenador de área que estará no pólo em regime de 15 horas semanais; tutoria a distância - será realizada por meio de fax, telefone e Internet; Cada aluno será acompanhado a distância, em cada disciplina, por docentes de reconhecida competência; Auxiliando tais professores haverá um corpo de tutores em nível de pós-graduação; Será criado um esquema de tarefas em que os estudantes contarão com um sistema de consulta capaz de esclarecer dúvidas por telefone, fax ou Internet.

O telefone, fax ou Internet não é reiterada aí de forma aleatória, mas como agente também participante do processo, aliás, de igual ou até maior importância. O 
enunciado tutoria a distância - será realizada por meio de fax, telefone e Internet alude, na verdade, à outra característica fundamental à industrialização do ensino - a mecanização. Sobretudo num contexto em que, cada vez mais, acentua-se a automação dos processos de ensino e aprendizagem, cujo maior expoente é a universidade virtual e global, a mecanização representa não apenas uma condição sine qua non, como também ocupa o lugar de protagonista na expansão e consolidação da educação a distância.

\section{Mecanização e virtualidade da educação}

As alusões à mecanização atravessam, praticamente, todo o T1, ganhando relevo desde a sdr 1 . Nos três segmentos que compõem a sequência, seja de forma referencial seja através de paráfrases, encontramos marcas textuais ou fragmentos que remetem aos processos mecânicos de ensino-aprendizagem. Mais do que a ênfase à SEED, que ali ocupa um lugar determinado historicamente mas que poderia ser assumido por qualquer outro representante designado pelo aparelho de Estado, o que marca o discurso de abertura da sdr 1 é a utilização intensiva das tecnologias de informação e comunicação no contexto escolar, buscando inovações tecnológicas e metodológicas para a melhoria da qualidade da educação no país.

Chama-nos a atenção, de imediato, o fato de que o enunciado utilização intensiva das tecnologias de informação e comunicação é típico à caracterização da EAD como forma avançada de industrialização do ensino, demarcando uma de suas principais distinções em relação à educação presencial. Se nesta, quando utilizadas, as TICs são empregadas gradativamente, na EAD torna-se crucial que sejam aplicadas constantemente, sob pena de rompimento do 
processo de ensino e aprendizagem a distância. Razão pela qual não observamos qualquer reticência por parte do sujeito do discurso nesse sentido, pelo contrário, até porque mobiliza ele uma formação discursiva responsável pela legitimação da ideologia da utilização intensiva das TICs no contexto escolar, seja virtual seja semi-presencial.

Logo em seguida, encontramos a alusão inovações tecnológicas e metodológicas associada diretamente à utilização intensiva das TICs, por relação de identificação, justaposição, ou mesmo, sobredeterminação. O que, a princípio, supõe que as tecnologias incluem-se entre as inúmeras manifestações do processo de inovação das metodologias e das técnicas em geral. No entanto, as reiterações ao longo da seqüência privilegiam as TICs como representando plena e legitimamente esse processo, aludido como de fundamental importância à melhoria da qualidade da educação no país.

Ainda no primeiro segmento que compõe a sdr 1, observamos três enunciados que retomam as TICs como referentes imediatos: tecnologias educacionais, conteúdos multimídia, TV Escola e Proinfo. Embora faça alusão a dois programas da SEED, referidos com nomes próprios, este último fragmento não deixa de produzir como efeito de sentido a idéia da TV e do computador como recursos ou inovações tecnológicas. No segundo e terceiro segmentos, apesar das referências reduzirem-se e se tornarem mais amplas, encontramos fragmentos que continuam invocando a presença das TICs. Além de educação a distância já se associar, quase que automaticamente, às tecnologias educacionais, os enunciados redes de colaboração e rede nacional de educação a distância logo fazem lembrar a rede mundial de computadores. O que permite incorporar ao discurso uma memória discursiva que atribui à internet 
a capacidade ilimitada e sem precedentes de formar uma "aldeia global", integrando e multiplicando os contatos e as parcerias, estratégicas ao Sistema UAB.

A propósito, o fragmento Sistema remonta aos sistemas de comunicação que, antes mesmo da idéia de rede, representam o que há de mais avançado em termos de meios de informação e comunicação. Estreitamente vinculadas a esses sistemas, vamos encontrar as tecnologias associadas às primeiras gerações da $\mathrm{EAD}$, em destaque a teleducação, potencializada nas últimas décadas pelos avanços da informática que resultam na videoconferência e na teleconferência. A referência Universidade Aberta, por sinal, faz alusão às tradicionais universidades a distância do mundo, em especial The Open University do Reino Unido, nascida nos anos 1960 originalmente como Universidade do Ar.

Como determinados discursos sempre se repetem, embora em contextos às vezes diferentes, o "argumento do uso da tecnologia para o avanço do conhecimento e para a expansão da educação no País" assumido pela The Open University (SANTOS, 2006, p.212) é retomado pelo Sistema Universidade Aberta do Brasil. Conforme demonstra o seguinte fragmento do T1 que imediatamente sucede a sdr 1, a perspectiva adotada deverá ir muito além da dimensão metodológica ou de mera aplicação da tecnologia no ensino, mas também de um sistema de educação a distância capaz de enfrentar os desafios dos baixos níveis de atendimento na educação superior.

Além disso, a UAB segue a pedagogia de ensino empregada pela The Open University ("Supported Open Learning" ou Aprendizagem Aberta Apoiada) que pressupõe a "combinação de métodos e mídias para o contato com o aluno, conhecida na área de educação a distância 
como 'blended learning' [...] Há também o contato presencial com o tutor, que não é obrigatório, e que acontece em média uma vez por mês." (SANTOS, 2006, p.216) Se na $\mathrm{UAB}$ os encontros presenciais aparentam ser estimulados, a aprendizagem a distância permanece entretanto como foco central. Nesse sentido, chama-nos a atenção o seguinte fragmento do T1: há que se fomentar o campo de pesquisas em tecnologias de informação e comunicação, outra importante missão para o Sistema Universidade Aberta.

Conseguimos apreender essa ênfase, melhor ainda, à medida que analisamos como se manifestam os vestígios da mecanização ao longo do texto, representados de modo exemplar por intermédio do seguinte fragmento: utilização de variadas tecnologias: impressos, vídeos, multimídia, Internet, fóruns virtuais e videoconferências. Como forma, inclusive, de avalizar essa recorrência, o sujeito do discurso finaliza o T1 adicionando um conjunto de onze Referências Bibliográficas, das quais apenas uma não faz menção direta às tecnologias: Diálogo para a cidadania e inclusão - Texto-Base. Isto porque se trata, a princípio, de um documento devotado a questões mais amplas envolvendo a educação. O que não impede, todavia, de vislumbrarmos no seu entremeio uma alusão importante nesse sentido, isto é, Diálogo que, no campo da EAD, logo remete a um processo de mediação.

Razão pela qual, seguindo inclusive as recomendações de um artigo acadêmico-científico, as Referências à mediação apresentam-se através de fragmentos bastante expressivos, desde educação a distância, Comunicação e educação até interface, Universidade Aberta e Sala de aula interativa. Alguns enunciados, além disso, são extremamente ricos de sentidos: Máquina e Imaginário: O desafio das Poéticas Tecnológicas; Novas tecnologias e mediação pedagógica; e, por 
último, Hipertexto, fechamento e o uso de não-linearidade discursiva. Apesar de produzir um efeito de sentido associado ao dialogismo, a mediação aí referida não poderia deixar de invocar os tradicionais e contemporâneos " mass media" (de onde deriva "mediação") que representam, em última instância, a incorporação à educação dos processos de mecanização e automação.

Ainda que a maioria das Referências não seja diretamente evocada ao longo do T1, observamos que a mecanização é a característica da industrialização do ensino que mais alusões recebe por parte do texto, de modo geral, dirigidas às TICs: recursos tecnológicos de informação e comunicação, infra-estrutura computacional e de telecomunicações, laboratórios de informática, mídias, entre outras. Ao lado destas, encontramos fragmentos que remontam às tecnologias tradicionais, tais como, equipamentos, diferentes suportes informacionais (conteúdos), conteúdos pedagógicos, ferramentas de comunicação e de material didático, material didático em mídia eletrônica e material impresso.

Mesmo assim, percebemos que a ênfase recai sobre as TICs, sobretudo quando relacionadas, caracterizadas ou comparadas aos suportes menos sofisticados: infra-estrutura física e logística de funcionamento (laboratórios didáticos e de informática, bibliotecas, recursos tecnológicos e outros); avanços dos recursos tecnológicos de informação e comunicação, especialmente das tecnologias digitais, potencializando práticas de EAD - as quais tradicionalmente estavam apoiadas em material impresso distribuído por correspondência. Essa evocação da relação tradicional-moderno, bastante representada por intermédio da evolução da tecnologia, é acentuada através de outros fragmentos que reforçam os avanços tecnológicos, a inovação tecnológica ou os ambientes e metodologias educacionais inovadores. 
Dessa forma, o sujeito do discurso nos seduz a professar com ele a fé de que a inovação pedagógica deriva, precipuamente, da modernidade tecnológica. $\mathrm{O}$ que implica a racionalização crescente das relações de ensino e de aprendizagem, mediante a qual a mecanização passa a constituir condição "sine qua non" à EAD, como bem demonstram os fragmentos que salientamos a seguir: Os pólos terão infra-estrutura computacional e de telecomunicações equivalentes às existentes nas universidades para as atividades de coordenação do pólo e tutoria; Além dessa infra-estrutura, os pólos contarão com laboratórios de informática para atendimento aos alunos e também com equipamentos para utilização das mídias necessárias ao curso.

A reiteração da infra-estrutura, através de referências, co-referências ou paráfrases, não é aleatória. Até porque, um pouco mais adiante do texto, chama-nos a atenção o seguinte enunciado: Serão considerados para efeito de seleção do pólo, especialmente, a análise da infra-estrutura física do pólo proposto e recursos humanos disponíveis. Não parece forçoso lembrarmos que a análise destes últimos deve levar em conta suas competências e habilidades no manuseio das TICs, não sendo qualquer profissional, portanto, que é convocado a participar do Sistema UAB.

A racionalidade deste no emprego da tecnologia chega ao ponto de induzir o próprio sujeito do discurso (e este, por extensão, o destinatário) a idealizar o sistema de biblioteca, como sugere o próprio nome, tal qual uma unidade de produção informacional, conforme ilustram os seguintes fragmentos: Como Unidade de Informação entende-se um sistema de recuperação de informação (SRI) informatizado que visa à gestão/organização; bem como ao planejamento, aquisição, processamento, armazenamento e disseminação/transferência da informação contida em documentos de diversas naturezas. 
Em meio aos fragmentos acima reproduzidos, encontramos mencionadas duas outras características da industrialização do ensino que não aparecem aí por acaso - gestão/organização e planejamento. Associadas a outras características da EAD - trabalho preparatório, métodos de controle científicos, formalização, padronização, objetivação, concentração e centralização, formam elas um conjunto de condições estruturais que, também, afetam o Sistema $U A B$, ampliando e potencializando os seus níveis de racionalidade. Por isso mesmo, decidimos analisá-las em conjunto, considerando não apenas que configuram reflexos importantes dos processos de racionalização, divisão de trabalho e mecanização, bem como estabelecem entre si laços fortes de interdependência, demarcados através de traços que atravessam o T1 no seu conjunto.

Do trabalho preparatório à centralização administrativa

O próprio T1 em si, além do que já assinalamos anteriormente, tem como propósito anunciar o Sistema $U A B$, exercendo uma função inerente ao trabalho preparatório, ao planejamento e/ou à organização em EAD. Influi sobre sua produção o fato de que a implementação, consolidação e legitimação da UAB pressupõe toda uma fase de preparação, envolvendo inclusive estratégias discursivas. Na sdr 1, já observamos traços expressivos nesse sentido, sintetizados por intermédio do seguinte fragmento: elaboramos este artigo com o objetivo de apresentar o Projeto Universidade Aberta do Brasil, suas bases e criação no âmbito do Fórum das Estatais pela Educação, e sua importância na consolidação da rede nacional de educação a distância, a qual estamos denominando Sistema Universidade Aberta do Brasil. 
Permite-nos compreender o fragmento que o texto faz parte de uma estratégia discursiva que tem origem no Projeto Universidade Aberta do Brasil que, portanto, lhe antecede. Representando o Projeto, desse modo, uma primeira instância de enunciação, responsável pela concepção da UAB que implica trabalho preparatório e planejamento, desenvolvidos por setores competentes e especializados. De sorte que o T1 passa a representar uma segunda instância de enunciação, destinada por seu turno a apresentar o Projeto Universidade Aberta do Brasil, suas bases e criação, bem como sua importância na consolidação do Sistema Universidade Aberta do Brasil.

Considerando que o sujeito do discurso é o mesmo da primeira e da segunda instância de enunciação, ao invés apenas de ter o sentido de expor ou dar a conhecer, o verbo apresentar acaba aludindo à tarefa reservada ao texto de preparar a adesão e o comprometimento dos setores interessados no Projeto $U A B$, antes mesmo de este ser implementado. Como requer qualquer processo de planejamento, muito mais ainda no âmbito das políticas públicas, isso pressupõe um trabalho de marketing voltado para garantir a necessária publicização, repercussão e aceitação do produto "UAB" junto à sociedade. Em se tratando de um discurso autoritário que já parte da presunção de sua importância [Projeto] na consolidação do Sistema $U A B$, o marketing assume maior relevância ainda, principalmente, porque cabe a ele, muitas vezes, produzir a opacidade do discurso.

Sob o predomínio dessa opacidade é que outras características da industrialização do ensino marcam a sdr 1. A organização é uma das principais a ser evocada, não sendo por acaso que a seqüência se vê atravessada pela referência, co-referência e paráfrase do substantivo projeto 
como símbolo, a um só tempo, do plano e do empreendimento de transformar em realidade a idéia da UAB. Os fragmentos que sublinhamos a seguir representam, por isso mesmo, vestígios importantes de uma formação discursiva caracterizada pela organização racional dos processos produtivos, em particular, de ensino e aprendizagem: programas TV Escola e Proinfo; programas de formação; projetos e programas; Projeto Universidade Aberta do Brasil (UAB); e, mais uma vez, Projeto Universidade Aberta do Brasil.

Signo também de um trabalho preparatório e do planejamento efetivo, a ênfase sobre a organização supõe, ainda, conceber a UAB do ponto de vista de uma estratégia de ação, nos moldes do caráter estratégico e da estratégia de trabalho colaborativo representados pela SEED. O que decorre de uma racionalidade que justifica, além disso, a alusão não apenas às bases e criação, como também à futura consolidação do Sistema $U A B$, indicando tratar-se de uma organização que se planeja tanto estrategicamente como em longo prazo, inclusive, estabelecendo de antemão suas formas de avaliação.

Embora referenciado uma única vez em meio à sdr 1, observamos que uma das ações estratégicas à SEED é o incentivo à pesquisa para o setor que remonta, em última instância, aos métodos de controle científico. Cruciais às políticas públicas tanto quanto o planejamento, cabe às pesquisas analisar o desempenho dos projetos e programas, com vistas a avaliar o cumprimento de objetivos e metas institucionais, bem como subsidiar a prestação de contas relativas aos seus resultados e impactos sociais. No caso da UAB não poderia ser diferente, assumindo a pesquisa o caráter [também] estratégico de efetuar, com base nos princípios de custo-benefício, eficiência, eficácia, produtividade, 
qualidade, entre outros, o controle rigoroso e permanente dos resultados obtidos durante toda a sua implementação e consolidação.

Esse controle serve, além do mais, para reforçar os níveis de formalização, padronização e objetivação típicos à produção industrial. Os enunciados regulamentação para educação a distância e Projeto Universidade Aberta do Brasil representam vestígios de uma racionalidade que transforma idéias e ações em projetos e programas formais, responsáveis por estabelecer previamente as diretrizes, metas e procedimentos a serem seguidos por todos os parceiros. Apesar de se colocar aberto ao diálogo ao apresentar o Projeto UAB, utilizando uma estratégia dialógica como já apontamos anteriormente, o sujeito do discurso refere-se na realidade a um projeto pronto e determinado por condições sócio-históricas anteriores que, portanto, pouco ou quase nada dependem da nova circunstância de enunciação em que se inscreve.

Paralelamente aos fragmentos de formalização, encontramos na sdr 1 traços característicos de um processo de padronização. Por um lado, faz-se alusão ao fato de a SEED constituir uma referência internacional, isto é, uma instituição à altura dos padrões internacionais em EAD, amplificando assim o seu caráter estratégico e sucesso alcançado na condução de projetos e programas. Por outro, seguindo essa mesma lógica de exemplaridade e exitosidade, faz-se menção à UAB como representando um modelo alternativo para a oferta e gestão de educação superior. A propósito, não qualquer modelo alternativo ao modelo presencial vigente no país, mas um modelo à altura dos padrões internacionais da Universidade Aberta e a Distância, testada, aprovada e consolidada em boa parte do mundo. 
Além de manifestar as características da formalização e da padronização, a sdr 1 vê-se afetada pela objetivação do processo de ensino-aprendizagem. Mesmo tendo em vista a democratização do acesso à educação superior pública, gratuita e de qualidade, conforme demonstram os fragmentos enfatizados a seguir, o sujeito do discurso é levado a conceber a UAB sob o prisma de uma estrutura complexa, na qual não há lugar para subjetividades. Até porque os sujeitos históricos convocados estão devidamente representados (para não dizer, assujeitados) pelas instituições as quais se encontram vinculados: rede nacional de educação a distância; Sistema Universidade Aberta do Brasil. Ele será formado pelas instituições federais de educação superior, em estreita relação com os Estados e Municípios, cristalizando a união de esforços das três esferas governamentais.

Os fragmentos nos ajudam a compreender, ademais, como a objetivação está associada a outras características da industrialização do ensino presentes na sdr 1 - concentração e centralização. Apesar da co-referência e da paráfrase se referir à mesma coisa, rede e Sistema não produzem um único efeito de sentido. A primeira remonta, sobretudo, a ideologia da integração nacional que, a todo custo, ganha força durante o Regime Militar, através de uma rede de telecomunicações, tornando-se fortemente atrelada à doutrina da segurança nacional. Ainda hoje, ela é evocada através da cadeia obrigatória de rádio e televisão formada para o "Pronunciamento à Nação do Excelentíssimo Senhor Presidente da República" e de outras "autoridades" ligadas aos poderes Executivo, Legislativo e Judiciário, além de se prestar à propaganda partidária e eleitoral.

Levando em conta a experiência estrangeira da "Universidade Aberta", o substantivo Sistema por sua vez 
seria redundante ou até desnecessário, não fosse sua razão de ser. Remonta ele os sistemas de EAD, essencialmente, caracterizados como organizações complexas, sob forte concentração de capital e centralização administrativa. Por essa razão, convém reiterarmos: Ele será formado pelas instituições federais de educação superior, em estreita relação com os Estados e Municípios, cristalizando a união de esforços das três esferas governamentais.

Como veremos agora através da análise do conjunto do T1, essas características típicas à iniciativa privada também afetam as políticas públicas, muito mais ainda, no contexto de um Estado neoliberal, racional por natureza, em que os discursos sobre desconcentração e descentralização caminham passo a passo aos processos de concentração e centralização. Vemos evidenciar-se, antes de tudo, que o discurso em torno do Sistema UAB reconhece a importância dos processos descentralizados. A ênfase sobre a consolidação e diversificação de experiências não deixa dúvida de que as novas ações devem ter como ponto de partida iniciativas já desenvolvidas.

O próprio emprego do verbo congregará, a princípio, dificulta-nos enxergar algum vestígio de discurso autoritário. Essa estratégia discursiva, porém, não se sustenta por muito tempo, entrando logo em contradição. Aquelas mesmas experiências antes enfatizadas acabam sendo questionadas, como representando tão somente ações que vêm ocorrendo de forma individualizada e não sistemática, com sobreposição de esforços e recursos. Além de promover a racionalização dos investimentos (isto é, sua concentração), cabe à UAB centralizar todas as iniciativas em torno de um Sistema, capaz de agregar e congregar, no sentido de administrar, gerenciar, coordenar, o conjunto das experiências. 
Na prática, o que se postula como consolidação e diversificação transforma-se em unificação das experiências, evocando assim outra característica do processo industrial - a padronização - que volta a se manifestar no T1. A nossa impressão inicial diante do texto é que se fala de um projeto pedagógico, a um só tempo, padronizado e não padronizado. No primeiro momento, o sujeito do discurso nos informa que o mesmo será unificado e que seu processo seletivo envolverá provas de Português, Matemática e Conhecimentos Gerais. No segundo momento, faz questão de ressalvar as particularidades de cada universidade em relação àquele mesmo projeto, além da condição autônoma para conduzir o processo de avaliação.

Esse jogo de linguagem, no entanto, serve para mascarar a ênfase sobre a padronização. Observando como se organiza hierarquicamente o próprio discurso, conseguimos perceber que o enunciado $O$ projeto pedagógico para o curso será unificado, mesmo aludindo a um fragmento que lhe antecede no segmento anterior - dezoito universidades federais [...] iniciarão os trabalhos para o desenho do projeto, deriva de um discurso autoritário que lhe força a anteceder qualquer observação relativa a outras particularidades ou polissemias. Notadamente, quando consideramos que aquele projeto diz respeito a um curso com oferta de dez mil vagas nacionais, o que difere de forma significativa do planejamento pedagógico circunscrito a uma instituição específica.

Do mesmo modo, posicionando-se em primeiro plano, o enunciado O processo seletivo constituir-se-á de provas de Português, Matemática e Conhecimentos Gerais não deixa margens para particularidades. A própria ressalva de que a instituição de ensino superior será autônoma para definir o modelo específico de avaliação não autoriza, automaticamente, 
o estabelecimento de um modelo particular. Como sabemos, o modelo de avaliação tradicionalmente adotado pelas comissões de vestibular das IFES, até por força da injunção de um processo seletivo, destina-se a selecionar os alunos com a melhor educação básica.

A referência à avaliação invoca outra característica da industrialização do ensino que incide sobre o T1 - a recorrência aos métodos de controle científicos. Os tópicos Alguns dados sobre oferta e atendimento na educação superior brasileira e Alguns dados sobre docentes e formação docente no Brasil representam, de antemão, uma profusão de parâmetros de análise de caráter extremamente racional, incluindo os seguintes exemplos: baixos indices de conclusão do ensino médio; indicadores que atendem ao disposto no Plano Nacional de Educação; Censo Escolar 2005; Esses números são relativamente mais amenos; perfil esse acima da média brasileira; desempenho dos estudantes nas avaliações realizadas pelo INEP/SAEB.

Os fragmentos que dizem respeito ao processo de avaliação e seleção dos pólos e cursos a distância são ainda mais ilustrativos de como os métodos de controle científicos afetam o T1, reforçando sua tendência à padronização e contrariando sua pretensão de se organizar como sistema aberto. A descrição detalhada dos critérios de análise e seleção representa forte indício de que o Sistema $U A B$ encontra-se submetido a um controle rigoroso. Acentua isso a reiteração, quase que literal, de uma série de fragmentos exemplares nesse sentido: carência de oferta, capacidade de oferta, quantitativo, infra-estrutura fisica, recursos humanos disponíveis e projeto pedagógico. Além deles, encontramos alusões a outros critérios tão ou mais importantes: adequação, conformidade, demanda, pertinência, cronograma de execução e localizações. 
Contudo, como se fosse necessário reforçar toda essa ênfase, o sujeito do discurso ainda acrescenta outro fragmento que não deixa de produzir o efeito de uma advertência:

Todas as propostas encaminhadas ao MEC serão analisadas e selecionadas por uma comissão de especialistas, tendo por critérios: consistência do projeto pedagógico e relevância do curso proposto, competência e experiência acadêmica da equipe docente responsável e coerência com a demanda da área geográfica de abrangência, atendimento da demanda do curso no pólo.

Logo em seguida, chama atenção o sujeito do discurso para a necessidade das IES, Estados e Municípios também se adequarem aos prazos estabelecidos com relação à participação no Sistema UAB. Consciente ou não, alude na realidade à outra característica do processo industrial - a formalização - que envolve o planejamento prévio e formal de cada etapa e de todo o ciclo de produção. Atravessando o T1 desde as alusões a regulamentações, propostas e projetos que culminam no Projeto/Sistema $\mathrm{UAB}$, a formalização afeta o discurso, de modo contundente, mediante os seguintes fragmentos: $A$ apresentação de propostas de projetos observará o seguinte cronograma: recebimento de propostas de 21 de dezembro de 2005 a 13 de abril de 2006; análise das propostas de 17 de abril a 30 de junho de 2006; divulgação dos resultados de 03 de julho a 07 de julho de 2006; e, finalmente, a formalização dos convênios aprovados de 10 de julho a 31 de agosto de 2006; No período de setembro de 2006 a 
fevereiro de 2007, serão realizadas as atividades para adequação dos pólos, preparação dos tutores, produção do material didático e demais ajustes; previsão de início dos cursos superiores para março de 2007.

Além de toda a tramitação das propostas de projetos, desde a sua apresentação, recebimento e conseqüente protocolização até a sua análise, divulgação dos resultados e formalização dos convênios, notamos que os procedimentos de formalização ainda são evocados pela produção do material didático, a previsão de início dos cursos superiores e demais ajustes que supõem a consideração daqueles de natureza formal. Essa ênfase sobre a formalização reforça, igualmente, a incidência sobre o texto de outra condição industrial, representada desta feita pelo trabalho preparatório.

Conforme observamos, a participação no Sistema $U A B$ envolve uma racionalidade institucional, administrativa e burocrática que pressupõe todo um esforço de preparação para se adequar aos seus critérios e prazos formais, mesmo numa fase de implantação em que a UAB será resultante da adesão voluntária. Sem se preparar racionalmente, seria difícil ao Sistema contabilizar quatrocentos e quatorze projetos de pólos de apoio presencial, bem como trinta e sete universidades federais e onze centros federais de educação tecnológica (Cefets) proponentes.

Conforme sugerem os últimos tópicos do T1, o Sistema em si já encerra um trabalho preparatório que tem início com O Projeto UAB no Fórum das Estatais pela Educação, evolui até $O$ Projeto-Piloto com o Banco do Brasil e $O$ Edital de Convocação das IES, Estados e Municípios para participarem da UAB, alcançando, finalmente, os Projetos encaminhados para avaliação. A alusão ao Projeto-Piloto, em particular, referencia a adoção de uma estratégia típica à organização industrial que costuma submeter a testes 
rigorosos a aceitabilidade e viabilidade de bens e serviços, antes de produzi-los e distribuí-los em larga escala. Como não deixa dúvida o sujeito do discurso, graças inclusive às parcerias, o Projeto-Piloto com o Banco do Brasil também sugere resultados promissores: dezoito universidades federais que já contam com infra-estrutura adequada para os cursos; iniciarão os trabalhos para o desenho do projeto pedagógico para o curso.

O Projeto-Piloto e mesmo todo o trabalho preparatório em torno da UAB fazem parte, em última instância, do processo de planejamento que constitui uma das características fundamentais à organização industrial. Ao longo do T1, encontramos um conjunto de vestígios que, a todo tempo, estão a lembrar que o Sistema UAB resulta de um plano baseado em condições sócio-históricas concretas e que, por isso mesmo, segue metas e procedimentos preestabelecidos, tanto racional quanto estrategicamente: questões estratégicas ligadas ao desenvolvimento sustentável do País; busca de solução para os problemas ligados à educação; ações de fomento e projetos voltados para a educação superior a distância.

Os enunciados que ressaltamos a seguir representam, melhor ainda, como o Sistema $U A B$ reporta-se a um processo de planejamento consideravelmente amplo e estratégico no âmbito do ensino superior que inclui desde a configuração de políticas, programas e projetos até o estabelecimento de metas e ações: A iniciativa integra importantes políticas públicas para a área de educação; programas voltados para a expansão da educação superior com qualidade e promoção de inclusão social; o projeto tem sido caracterizado pela reafirmação do caráter estratégico desse nível educacional, do desenvolvimento científico e da inovação tecnológica para o crescimento sustentado do país; metas e ações para a promoção da educação inclusiva e cidadã. 
O planejamento de um sistema com a amplitude da $\mathrm{UAB}$, por extensão, não pode ficar a cargo de um modelo simples de administração, mas submetido a uma gestão complexa, típica à organização industrial. Conforme indicam a princípio alguns fragmentos e enunciados, o sujeito do discurso reporta-se a uma estrutura sistêmica, com a autonomia necessária ao seu funcionamento e à participação eqüitativa dos participantes: desenvolvimento do trabalho de gestão da educação superior na dinâmica de rede, propiciando trabalho colaborativo para o desenvolvimento institucional; adesão voluntária de 55 universidades federais, além do conjunto de centros federais de educação tecnológica, articulados e integrados com a rede de pólos de apoio presencial para EAD.

Aprofundando a análise do T1, percebemos entretanto que o Sistema $U A B$ reproduz o modelo de administração tradicional, consolidado pela organização industrial moderna e ainda vigente no mundo contemporâneo. A recorrência a esse modelo encontra sua maior expressão por ocasião de uma analogia que o sujeito do discurso produz, ao discorrer sobre o Projeto-Piloto da UAB (a propósito, resultante de parceria especial do Banco do Brasil e demais bancos estatais que constituem empresas organizadas nos moldes convencionais, incluindo uma gestão verticalizada): Pretende-se que o sistema de biblioteca seja idealizado como uma Unidade de Informação.

Ao considerar o sistema de biblioteca como uma Unidade de Informação, o sujeito do discurso reporta-se ao modelo fundante da organização industrial - a Unidade de Produção. O que pressupõe que a idéia que elabora relativamente ao Sistema UAB como um todo, também, deriva do mesmo modelo. Daí podermos supor que, na verdade, o sujeito do discurso produz uma analogia nos seguintes termos: Pretende-se que o Sistema UAB seja idealizado como uma Unidade de Produção. 
O primeiro vestígio que encontramos nessa direção refere-se à estrutura da Unidade de Produção (leiamos Sistema $U A B)$. Logo de início, ela é subdividida, por seu turno, em duas unidades elementares à qualquer organização industrial - a unidade-base e as unidades-pólos: $a$ estrutura inicial do sistema deverá ser composta de uma unidade de informação-base (biblioteca-sede) e demais unidades de informação-pólos (bibliotecas nos centros regionais de desenvolvimento). Por extensão, isso significa referenciar a SEED/ MEC como sede e as IES e os pólos de apoio presencial (mantidos pelos Estados e Municípios) como centros regionais de desenvolvimento do sistema, sem deixarmos de levar em conta a participação de outras instâncias no processo (Fórum das Estatais pela Educação, demais secretarias e órgãos do $M E C$, novos e diferenciados partícipes, entre outros).

A não ser pelos indícios de formalização (unidade de informação-base no início e, mais adiante, demais unidades de informação-pólos), até essa altura não conseguimos entretanto apreender como se estrutura hierarquicamente a Unidade de Produção, isto é, de forma vertical ou horizontal. No transcorrer do texto é que começamos a encontrar fragmentos de uma tendência verticalizada, em conformidade com uma tradição cara à organização industrial. Antes e acima de tudo, caberá fundamentalmente à unidade-base responsabilizar-se pela definição e condução das politicas e diretrizes gerais do sistema, o que nos faz lembrar as ações que contribuem para a SEED consolidar-se como referência internacional e de caráter estratégico para a educação brasileira.

Como se o sujeito do discurso estivesse se referindo amplamente a uma Unidade de Produção e não mais apenas a uma Unidade de Informação, assinala ele que cabe às unidades-pólos por sua vez responsabilizar-se pela 
implementação, execução e manutenção do sistema. O que inclui desde o suporte informacional ao ensino, acesso aos conteúdos pedagógicos e às tecnologias de informação pertinentes até o apoio aos sistemas de tutoria presencial e a distância, fazendo-nos recordar o compromisso inalienável dos parceiros de projetos. Em outras palavras, enquanto a SEED assume importância capital ao sistema, ligada inclusive ao postulado de que a educação superior conforma-se como estratégia basilar para o desenvolvimento nacional sustentável, as IES e os pólos de apoio presencial ocupam uma relevância secundária, em atendimento a metas básicas para o desenvolvimento regional sustentável.

A recorrente alusão ao desenvolvimento nacional e ao desenvolvimento regional ajuda-nos a compreender, igualmente, a incidência no T1 de outra condição "sine qua non" ao processo industrial - a produção de massa. Sem apoio de uma oferta de ensino em grandes proporções, praticamente, seria impossível planejar e consolidar um sistema de educação a distância capaz de enfrentar os desafios dos baixos níveis de atendimento na educação superior, da concentração da oferta nos grandes centros, e das limitações do modelo vigente de financiamento. Desde a sdr 1, observamos que o texto é constantemente perpassado por um enunciado-síntese de todo um discurso em torno da UAB: democratização da educação superior e formação inicial e continuada de professores.

Produção de massa como forma de democratização do ensino

Dois enunciados, em especial, lançam vestígios dessa característica industrial sobre a sdr 1: oferta e gestão de educação superior e democratização do acesso à educação superior. Precisamos compreender, notadamente, que oferta e gestão e democratização não se traduzem por meio de um único 
sentido. A primeira expressão alude, diretamente, à produção de massa, caracterizada pela gestão racional de bens e serviços em larga escala e cuja oferta é organizada na proporção do contingente e das demandas específicas dos consumidores. No que diz respeito ao Sistema $U A B$ de acordo com as potencialidades e demandas nacionais de acesso à educação superior, daí se entender por que o sujeito do discurso faz questão de retomar Alguns dados sobre a formação docente e em nível superior no país.

O substantivo democratização, apesar de estar associado a acesso que também remete à produção de massa, alude em parte à outra formação discursiva, representada pela educação superior pública, gratuita e de qualidade. Recorre, dessa forma, ao princípio que inclui a educação entre os direitos e garantias fundamentais ao cidadão, o que transcende as chamadas leis de mercado, estabelecidas a partir das condições concretas e materiais de oferta e procura. Como esclarece Khôi (1970, p.256), devemos definir "a democratização não pela igualdade teórica de acesso ao ensino, mas pela igualdade efectiva das possibilidades dadas a cada pessoa de desenvolver todas as suas faculdades".

Acontece que, conforme já nos advertia Peters (2003b, p.92), em países extensos como o nosso em que as demandas pressupõem "mass higher education", a democratização da universidade não pode ser pensada senão em termos de atendimento de massa, "sequer é possível sem esse tipo de oferta de ensino." O que nos permite entender porque, na realidade, para o sujeito do discurso não representa contradição alguma associar nem tampouco aproximar oferta e gestão de democratização. Essa aproximação não se dá apenas através dos fragmentos sublinhados, mas a partir de uma relação estabelecida entre quatro enunciados, 
referenciados entre o segundo e o terceiro segmento da sdr 1: Projeto Universidade Aberta do Brasil, modelo alternativo para a oferta e gestão de educação superior, Sistema Universidade Aberta do Brasil e democratização do acesso à educação superior pública, gratuita e de qualidade.

A relação entre os enunciados se estabelece em dois momentos - no interior de cada segmento através de parafrasagem e, no âmbito dos dois segmentos, mediante o emprego de uma espécie de cadeia de referência. No segundo segmento da sdr 1, observamos uma relação em que o enunciado modelo alternativo para a oferta e gestão de educação superior, ao mesmo tempo, alude e parafraseia o referente Projeto Universidade Aberta do Brasil. Até então representando (inclusive, confundindo-se com o referente ano de 2005) um marco histórico para a educação a distância no País, o Projeto ganha um novo sentido que referencia sua importância agora como modelo alternativo ao modelo convencional de oferta e gestão de educação superior - conforme lembra uma determinada memória discursiva - caracterizadamente presencial.

No terceiro segmento da sdr 1 , notamos uma relação em que o enunciado democratização do acesso à educação superior pública, gratuita e de qualidade, igualmente, faz menção e serve de paráfrase ao referente Sistema Universidade Aberta do Brasil. Até então concebido como representando a rede nacional de educação a distância, além de agregar um segundo sentido - o de, sugestivamente, cristalizar a união de esforços das três esferas governamentais, o Sistema adquire um terceiro significado. Reportando-se este à democratização do acesso à educação superior pública, gratuita e de qualidade - conforme, também, lembra uma determinada memória discursiva - tradicionalmente elitista. 
O estabelecimento da relação entre os enunciados por intermédio de uma espécie de cadeia de referência, por sua vez, incide sobre os dois segmentos a um só tempo. Consideramos, por um lado, que ao pronunciar Sistema Universidade Aberta do Brasil o sujeito do discurso evoca, quase que de imediato, Projeto Universidade Aberta do Brasil e vice-versa, devido ao fato inclusive de um enunciado pressupor o outro. Por outro lado, ao mencionar democratização do acesso à educação superior pública, gratuita e de qualidade o sujeito do discurso alude, de forma quase automática, modelo alternativo para a oferta e gestão de educação superior, enunciado com o qual mantém uma relação de aproximação muito forte.

Examinando os enunciados no seu conjunto, percebemos que a relação estabelecida entre os mesmos é de causa e efeito, ou melhor, entre meios e fins. Enquanto Projeto, a Universidade Aberta do Brasil constitui instrumento estratégico para propor um modelo alternativo para a oferta e gestão de educação superior. Enquanto Sistema, a UAB representa iniciativa sem precedentes para garantir a democratização do acesso à educação superior pública, gratuita e de qualidade. Em suma, os enunciados se encadeiam para reiterar que, seja na forma de Projeto seja na forma de Sistema, a UAB encerra, por excelência, um modelo alternativo para a gestão e democratização da educação superior pública, gratuita e de qualidade.

Ao longo do T1, esse postulado é retomado através de uma alusão constante ao enunciado-síntese democratização da educação superior e formação inicial e continuada de professores. Dois tópicos do texto, inclusive, são direcionados nesse sentido: Alguns dados sobre oferta e atendimento na educação superior brasileira e Alguns dados sobre docentes e formação docente no Brasil. Além disso, os fragmentos que 
evocam o enunciado-síntese são por demais recorrentes, incluindo desde aqueles que são reiterados até aqueles que acabam formando uma extensa família parafrástica: acesso ao conhecimento e aos níveis mais elevados de educação; expressiva demanda por formação superior inicial e continuada; democratização do acesso ao ensino superior; expansão da educação superior com qualidade e promoção de inclusão social; educação superior para todos, com qualidade e democracia; oferta de educação superior por meio da modalidade de educação a distância.

Essa recorrência sistemática ao enunciado-síntese induz o sujeito do discurso, por um lado, a mobilizar como contraponto fatos que corroboram a debilidade, fragilidade, ou melhor, uma espécie de irracionalidade da formação superior e continuada no país. Em outras palavras, uma realidade que não deixa dúvidas sobre a elitização da educação superior e formação inicial e continuada de professores no Brasil. De sorte que encontramos um conjunto de enunciados que reiteram os problemas e desafios enfrentados na área: baixos índices de acesso à educação superior; número insuficiente de vagas no setor público; forte desigualdade de acesso ao ensino superior, em especial, da população menos favorecida economicamente; discrepâncias regionais marcantes.

A irracionalidade da formação superior e continuada no país ganha maior relevância, contudo, à medida que são acentuados os seus déficits em termos estatísticos: apenas 10,5\% da população brasileira, com idade entre 18 e 24 anos de idade, têm acesso à educação superior, valor inferior ao de países como a Argentina (40\%), Venezuela (26\%), Bolívia $(20,6 \%)$ e Chile $(20,6 \%)$; demanda reprimida por vagas, acarretada pela concentração da oferta em praticamente $30 \%$ dos nossos municípios; Dos 2,9 milhões de funções docentes, cerca 
de 1,1 milhão, ou 38,1\%, não têm licenciatura completa. O que nos permite compreender que o sujeito do discurso não recorre aleatoriamente a essas estatísticas; pelo contrário, busca a partir delas consubstanciar e legitimar uma ação (Sistema UAB) que não apenas se mostra estratégica, como também requer ser aplicada em larga escala.

Por outro lado, mobilizando como ponto de apoio fatos que demonstram a potencialidade ou racionalidade da democratização da educação superior e formação inicial e continuada de professores no Brasil, o sujeito do discurso evoca dois tipos de demandas que acometem o país. Muito embora não sejam excludentes e, muitas vezes, mantenham relações intrínsecas, essas necessidades caracterizam-se como profissionais e geográficas, destacando-se em meio a estas últimas os seguintes enunciados: capilarização e interiorização da oferta; atendimento das demandas nacionais reprimidas; aumento da oferta nas regiões distantes dos grandes centros; demanda local ou regional por ensino superior público. Essas demandas tornam-se ainda mais incisivas à medida que o sujeito do discurso lança mão de fragmentos que se reportam a fatos e números que, dificilmente, seriam alcançados senão mediante um sistema de educação a distância capaz de suprir, plenamente e em tempo recorde, necessidades do país como um todo: quatrocentos e nove municípios proponentes, totalizando quatrocentos e quatorze projetos de pólos de apoio presencial, em todas as vinte e sete unidades da federação; trinta e sete universidades federais e onze centros federais de educação tecnológica (Cefets) proponentes.

Além das demandas geográficas, o sujeito do discurso recorre a fragmentos e enunciados que fazem alusão a demandas profissionais, também, importantes para reforçar o caráter racional e urgente tanto da formação em 
nível de licenciatura como da construção e execução de amplo programa nacional de formação em serviço, para os servidores públicos, tendo em vista a enorme demanda desse tipo de formação nas esferas estaduais e municipais. Os indícios que destacamos a seguir são veementes nesse sentido, revelando como o sujeito do discurso justifica e até naturaliza a implantação do Sistema $U A B$ em razão das demandas profissionais vigentes no país: parece natural supor que devemos traçar politicas públicas que visem levar a formação em nível superior - com qualidade - a todos os professores que atuam ou que venham atuar na educação infantil, fundamental ou média; Não obstante os diversos programas e ações coordenados pelo MEC nos últimos anos terem contribuído bastante para melhorar o quadro geral de formação de professores no Brasil, os números aqui mostrados - em conjunto com a complexidade social, econômica e geográfica indicados anteriormente - revelam que é grande o desafio de se constituir um sistema educacional que garanta o acesso de todos ao conhecimento e aos niveis mais elevados de educação preconizado no Texto Maior.

Aqui o próprio sujeito do discurso provoca a descontinuidade deste, pelo menos, até quando passamos a compreender que o "outro" discurso por ele mobilizado é mais complementar do que antagônico. Não há dúvida de que os diversos programas e ações coordenados pelo MEC nos últimos anos são questionados e relativizados, como não tendo sido tão eficazes. Essa ineficácia, ao invés de produzir o efeito de uma contradição, é empregada muito mais como pretexto para o sujeito do discurso justificar a adoção das [novas] medidas criadas por parte do Ministério da Educação, cuja racionalidade desta feita se coloca a toda prova: o desenho proposto para o Sistema Universidade Aberta do Brasil, apresenta forte potencial de solução para esse quadro. 
O potencial de solução aí aludido não trata, portanto, de qualquer potencial, mas daquele forte o bastante para garantir efetivamente a democratização da educação superior e formação inicial e continuada de professores. O que precisamos entender, todavia, é que a democratização que o sujeito do discurso evoca não tem um fim em si mesmo, pelo contrário, somente ganha sentido à medida que é relacionada a sua finalidade mais ampla, representada pelos efeitos da expansão da formação superior e continuada na sociedade contemporânea:

Trata-se de um marco histórico para a educação brasileira e que será amalgamado na produção coletiva de iniciativas compatíveis com a necessidade de revigoramento do modelo de formação superior no Brasil - tradicionalmente baseado em formação acadêmica inicial - e no repensar a educação ao longo da vida.

Outros fragmentos nos ajudam a perceber, melhor ainda, que um projeto de democratização da formação superior e continuada que tem como finalidades responder à emergência de novas competências para o trabalho, provocadas pelos constantes avanços tecnológicos, novo modelo de desenvolvimento econômico brasileiro e desafios impostos pela sociedade global e do conhecimento, apenas e tão somente, pode ser pensado nos marcos de um sistema de produção de massa. De um sistema, por um lado, capaz de universalizar tanto a formação inicial como a formação continuada ao longo da vida, garantindo o acesso de todos ao conhecimento e aos níveis mais elevados de educação preconizado no Texto Maior. Por outro, capaz de atender às progressivas e 
profundas reestruturações das relações profissionais que forçam, obrigatoriamente, a adoção de políticas públicas que visem levar a formação em nível superior - com qualidade - a todos os professores que atuam ou que venham atuar na educação infantil, fundamental ou média.

Teoria pós-industrial e teoria do capital humano (ALMEIDA, PEREIRA, 2000; PAIVA, 2001; SAUL, 2004) parecem se juntar em um mesmo discurso - que vai do Texto Maior ao T1, retomando e desencadeando outros infinitos textos - em favor da democratização da educação superior e formação inicial e continuada de professores. A evidência dessa justaposição nos é possível, mais precisamente, à medida que o sujeito do discurso faz questão de fazer a seguinte ressalva à UAB: Em relação à flexibilidade curricular, deverá ser adotado um conjunto de procedimentos visando orientar o aluno na escolha de uma trajetória adequada à sua disponibilidade tempo de estudo e sua formação anterior. A flexibilidade não deixa de aludir a um Sistema destinado à produção de massa que necessita se adaptar, sistemática e constantemente, às demandas contemporâneas da sociedade industrial e de consumo.

\section{Continuidades e regularidades do discurso industrial}

Apesar de apresentado como um marco histórico para a educação a distância no País, o Sistema UAB não representa o único nem tampouco o primeiro programa do governo federal que visa a democratização da educação superior e formação inicial e continuada de professores. Na realidade, o programa retoma um ideal que atravessa, pelo menos, as últimas seis décadas de história do Estado brasileiro, mantendo-se fortemente presente ao longo de toda a evolução da política nacional de EAD. O que o faz transitar e 
transcender, durante esse período, tanto as configurações assumidas pelo Estado (Estado Providência, interventor, neoliberal etc.) como as orientações político-ideológicas de cada governo (populista, militar, democrático etc.).

Conforme veremos a partir da análise do conjunto do corpus discursivo, trata-se de um ideal que não apenas traduz a prevalência de uma característica (produção de massa), como também faz alusão a outras condições estruturais que marcam a incidência do discurso da industrialização do ensino sobre a política de EAD. A primeira evidência disso se dá quando comparamos o enunciado-síntese do T1 àqueles que poderíamos chamar enunciados-sínteses dos demais textos, ainda que tomemos como referência, no caso destes últimos, apenas a sdr selecionada: T2) democratização e melhoria da qualidade da educação pública brasileira; T3) treinamento de professores; T4) formação inicial e continuada do cidadão brasileiro; T5) formação e reciclagem de professores; T6) qualificação; T7) democratizar o sistema educativo, orientando-o no sentido de contribuir para a correção das injustiças e discriminações; T8) proporcionar universal oportunidade de educação no Brasil inteiro; T9) promoção de tal educação em massa; T10) na luta pela disseminação da instrução, bem como na promoção do treinamento profissional.

Percebemos, de antemão, que o enunciado-síntese do T1 retoma duas questões centrais aos demais textos, a saber, a universalização da educação (reatualizada como democratização da educação superior) e a qualificação profissional (reatualizada como formação inicial e continuada de professores). A primeira questão remonta os textos 2, 4, 7, 8 e 9, não restando dúvida de que a universalização aí postulada acaba fazendo prevalecer a produção e oferta de uma educação em massa. À exceção de um texto dos anos 1960 que ainda se permite utilizar da expressão educação 
em massa, a transparência do discurso nos demais textos cede lugar a um jogo de linguagem que atribui a determinados termos e expressões (democratização, formação, democratizar, universal oportunidade e promoção) a capacidade de dar sentido àquilo que interessa ao sujeito do discurso.

A segunda questão remonta, por sua vez, os textos 3, 5 e 6, não havendo dúvida de que a qualificação aí pretendida faz prevalecer o treinamento e a reciclagem, também, em massa. Não encontramos exceções aqui, até porque desde os anos 1970 o discurso sobre a preparação para o mercado de trabalho costuma empregar a mesma objetividade: treinamento, qualificação, formação e reciclagem. Processos que se dão, principalmente, no contexto da produção e oferta de uma educação profissional destinada a grandes contingentes de trabalhadores, seja da esfera privada seja da esfera pública, como é o caso dos professores da rede pública de ensino.

Mais interessante, ainda, é observarmos que o enunciado-síntese do T1 retoma, em grande medida, o enunciado-síntese do T10. Quase seis décadas depois, é como se a democratização da educação superior e formação inicial e continuada de professores produzisse como efeito de sentido representar mais um esforço na luta pela disseminação da instrução, bem como na promoção do treinamento profissional. No entanto, o sujeito do discurso ignora, ou mesmo, faz questão de apagar essa memória discursiva, a ponto de considerar o Sistema UAB como um marco histórico para a educação a distância no País, portanto, um esforço sem precedentes e definitivo.

Cabe à memória discursiva, não obstante, exercer um papel importante no sistema de enunciabilidade que faz prevalecer o discurso da produção de massa no corpus em estudo. Em todos os textos, o sujeito do discurso sempre 
está a evocar uma educação produzida em larga escala, objetivando alcançar segmentos amplos da população ou do sistema de ensino. Essa recorrência, aliás, não se resume aos enunciados-sínteses, mas envolve uma série de fragmentos e enunciados que não aparecem aleatoriamente em meio aos textos.

Os textos, antes de tudo, são marcados por uma alusão constante à EAD como produção de massa. A recorrência aos enunciados TV Escola, Radiodifusão Educativa, teleducação, instrução pelo rádio e televisão, instrução por TV e ensino por correspondência mobiliza uma memória discursiva que concebe a educação como ofertada por intermédio de tecnologias ou meios de comunicação, caracterizadamente, de massa (correios, rádio, televisão etc.). A própria evolução da expressão escola à distância da sdr 10 para educação a distância da sdr 1 evidencia não exatamente um processo de desinstitucionalização, mas de amplificação e mesmo superação das fronteiras da escola ou da educação presencial, reafirmando a idéia de não haver limites para a expansão do ensino industrializado.

Essa idéia de massificação típica à EAD, de fato, acompanha o discurso em torno da política de educação a distância, desde os anos 1950. Ali já encontramos fragmentos e enunciados que, por um lado, evocam a intensidade de aplicação da EAD: amplamente utilizado; em numerosas regiões do globo; milhões e milhões de pessoas, anualmente, iniciam e prosseguem estudos. Por outro, aludem à amplitude de seu alcance: A todos esses, assim como a diversos outros grupos; é que a escola vai, sob a forma de ensino por correspondência, ministrando-lhes, não só instrução acadêmica dos três níveis (primário, secundário e superior), mas também treinamento profissional de vários graus e categorias. Não vemos aí, é bom frisarmos, menção a individualidades, mas uma 
série de alusões a coletividades, seja na forma de regiões ou de grupos de pessoas, seja na forma de níveis de educação ou treinamento.

Nos anos 1960, como destacamos acima, a idéia da massificação é inclusive referenciada diretamente, através do enunciado-síntese da sdr 9 - promoção de tal educação em massa. Mas outros fragmentos e enunciados reforçam esse discurso por meio de parafrasagem, tanto ao nível daquela seqüência como da sdr 8: impacto total em uma nação; aumentará grandemente o número de estudantes a receberem boa educação, especialmente em áreas rurais; maiores oportunidades para educação de mulheres; podem vir a ser usados nas escolas de todo o Brasil; uma solução para o problema educacional do país. Mais incisivas, ainda, são as seguintes alusões que revelam um sujeito do discurso significativamente afetado pela produção de massa: era da educação e da alfabetização universais e tornar o Brasil capaz de usufruir as vantagens de oportunidade universal de educação, no futuro próximo, a um custo razoável.

Melhor síntese de que a produção de massa continua prevalecendo nos anos 1970 são duas referências que se completam. Através da sdr 6, evoca o sujeito do discurso o alto indice que uma clientela específica, por força de dificuldades de comunicação, acesso e infra-estrutura, demanda em termos de qualificação profissional: cerca de 150 a 200 mil professores leigos, em exercício do magistério nas quatro primeiras séries do ensino de $1^{\circ}$ grau, em todo o território nacional. Antes mesmo disso, mediante a sdr 7, faz alusão aquele sujeito ao Projeto Nacional de Teleducação que tem em vista a própria universalização do ensino. Já antevendo o que vai ser retomado nos anos 2000 por parte do T1, como vimos anteriormente, essa universalização encontra-se atrelada tanto às exigências do desenvolvimento nacional como da 
sociedade pós-industrial: adaptadas ao estágio de desenvolvimento do País, permitindo assim maior amplitude e flexibilidade ao processo educacional; hão de fazer da escola do futuro uma estrutura mais aberta e flexível, oferecendo a todos oportunidades de formação segundo suas capacidades.

Essas exigências, até por força da emergência da globalização da economia, mantêm-se presentes nos anos 1980. Em meio à sdr 5, observamos fragmentos e enunciados que se reportam desde o apoio ao pré-escolar e o cumprimento curricular do Supletivo de $1^{\circ}$ e $2^{\circ}$ graus até o desenvolvimento de ações sócio-educativas e culturais que não deixam de aludir ao processo de mundialização da cultura e da expansão da chamada sociedade da informação e do conhecimento. A ênfase do sujeito do discurso recai, entretanto, sobre a própria complexidade e amplitude do Sistema Nacional de Radiodifusão Educativa. Apesar de ser integrado hoje por 14 emissoras de televisão, 340 repetidoras de televisão e 22 emissoras de rádio educativas que alcançam 300 municípios em todo o País, com audiência estimada de 32 milhões de pessoas, o que se encontra em questão é o fortalecimento desse sistema: A consolidação, o aperfeiçoamento e a expansão da televisão e do rádio Educativos. Do que decorre que a recepção organizada reivindicada para um sistema com tal magnitude não poderia ser outra senão nos moldes da produção de massa.

Durante os anos 1990, o atendimento dessa recepção organizada em forma de massa constitui uma preocupação central. Examinando a sdr 4, o que vamos perceber é que a capacitação da força de trabalho nacional, em especial dos professores da educação básica passa, inclusive, por essa orientação. Cabe ao Programa Nacional da Educação à Distância promover a ampliação da rede de escolas equipadas, no sentido de atender à clientela do ensino fundamental: 
alunos, professores e gestores. Considerando agora a sdr 3, através da qual o sujeito do discurso faz questão de lembrar que o que estávamos fazendo, paulatinamente, era ir treinando as pessoas e ir conquistando os professores para o uso da TV Escola, esse universo já atinge 50 mil escolas em todo o Brasil, chegando a resultados não menos exitosos: Com apenas um ano de funcionamento a TV Escola tinha $75 \%$ dos equipamentos funcionando, em uso na sala de aula, com alguma utilização no treinamento de professores, ou seja, com alguma utilização pedagógica. Hoje, temos muito mais.

A alusão à recepção organizada, ou mesmo, utilização pedagógica da TV Escola e outros programas de EAD permanece sendo enfatizada nos anos 2000. Na sdr 2, encontramos fragmentos e enunciados que reforçam a sua importância inclusive para enriquecer o ensino presencial junto à escola pública do país, o que remete a um sistema educativo de dimensões continentais. Não esquecendo de situar tais ações no contexto de uma política e de programas de abrangência nacional, evoca o sujeito do discurso ademais o aperfeiçoamento e capacitação de professores do ensino básico, antecipando aquele mesmo desafio que no T1 atribui ao Sistema Universidade Aberta do Brasil equacionar.

Os fragmentos de intertextualidade e, melhor ainda, de interdiscursividade da industrialização do ensino presentes ao longo do corpus discursivo não se restringem às reiterações à produção de massa. A esta se associam outras características que demonstram como o sujeito do discurso é afetado, a todo momento, por uma formação discursiva que insiste em prevalecer frente à história. $\mathrm{O}$ que significa que, ao encontrarmos vestígios no T1 do trabalho preparatório, planejamento, organização, métodos de controle científicos, assim por diante, deparamo-nos muitas vezes com recorrências que já incidiram sobre outros textos. 
Destaca-se, nesse sentido, o fato de todos os textos evocarem a centralização administrativa. A mesma SEED que ganha relevo no T1, como examinamos anteriormente, já prevalece na sdr 2, representando uma estrutura de governo vinculada ao Ministério da Educação responsável por uma política de EAD, em plena década de 2000, fortemente centralizada. Apesar de a SEED ser referenciada indiretamente através das inúmeras recorrências à $T V$ Escola, na sdr 3 ela cede lugar ao Ministério da Educação, mesmo porque - convém acentuarmos - o locutor da ocasião é o próprio ministro, o que só fortalece a centralidade do discurso. Através da sdr 4, porém, vamos observar que o MEC já se encontra representado pela SENEB, a Secretaria Nacional de Educação Básica, o que remete ao fato de a política de EAD, nos anos 1990, concentrar-se no âmbito do ensino fundamental e médio.

Os anos 1980, por sua vez, são marcados por uma referência quase que literal à centralização administrativa. Acontece que, desta feita, a sdr 5 é atribuída ao próprio último presidente do Regime Militar que não parece medir as palavras para dar sentido a uma das estruturas de comando daquele governo, a FUNTEVÊ: A Fundação Centro Brasileiro de Televisão Educativa, criada pela Lei $n^{o}$ 5.198/67, tem coordenado as atividades no âmbito das tecnologias educacionais, concentrando os planos e a administração destas técnicas dispersos até 1982.

A centralização da política de EAD, porém, já se faz presente ao longo dos anos 1970, graças inclusive à plena vigência do Regime Militar. Por um lado, conforme observamos através da sdr 6, cabe ao DSU/MEC (Departamento de Ensino Supletivo) ocupar essa centralidade, razão que explica porque o sujeito do discurso evoca a sua pronta diligência: O Departamento resolveu então partir para uma 
ação supletiva na tentativa de resolução do problema. Por outro, como demonstram de modo particular dois fragmentos da sdr 7, compete ao Ministério da Educação e Cultura assumir diretamente essa condição: motivos que levaram o MEC a incluir, entre os projetos prioritários do Plano Setorial de Educação e Cultura 1972/74, o Projeto Nacional de Teleducação ( $\left.N^{0} 36\right)$, com o objetivo de coordenar, integrar e sistematizar a utilização das tecnologias educacionais; Com o novo Plano Setorial para 1975/79, extingue-se o Projeto $N^{0} 36$, substituído pelo Projeto $N^{0} 7$. Se os verbos de ação coordenar, integrar e sistematizar já invocam um sujeito agente, incluir e extingue-se referem um poder de deliberação que não deixa dúvida sobre o fato de se encontrar acima de outras instâncias.

Algo semelhante se dá durante os anos 1960, período em que a educação a distância já faz parte das preocupações centrais do Conselho Nacional de Pesquisas, o antigo $\mathrm{CNPq}$ que centraliza então a política nacional de ciência e tecnologia. Vestígio importante, nesse sentido, é o seguinte fragmento que encontramos em meio a sdr 8: Em 1966 a Comissão Nacional de Atividades Espaciais (CNAE) iniciou um estudo e, em 1967, propôs medidas a serem tomadas pelo Conselho Nacional de Pesquisas visando a uma solução para o problema educacional do país. Embora a sdr 9 não faça referência direta a um órgão específico de comando, ao aludir que o plano educacional deve proporcionar um programa devidamente equilibrado, o sujeito do discurso acaba invocando, por excelência, o Ministério da Educação e Cultura. Cabendo ao MEC, desta feita, tomar medidas objetivando melhor organização e mais homogeneidade no sistema de educação com maior participação da comunidade. A participação aí aludida, decerto, deriva de uma estratégia discursiva voltada para ocultar o processo de endurecimento do Regime Militar. 
A sdr 10, também, não se refere a um eventual órgão de comando, porém nos oferece pistas significativas para compreendermos como a centralização administrativa já incide sobre a política de EAD, nos anos 1950: o que os alemães chamam de "escola à distância" (Fernschule); Graças a êle, em numerosas regiões do globo, como sejam, entre outras, os Estados Unidos e a Rússia, a Inglaterra e a Commonwealth, a França e a Alemanha, os Países Escandinavos e o Japão, milhões e milhões de pessoas, anualmente, iniciam e prosseguem estudos. Quando associamos a esses fragmentos o enunciado importantíssimo e eficaz instrumento, que não pode ser abandonado e que cumpre, muito pelo contrário, estimular e desenvolver, percebemos que esta última expressão invoca uma estrutura de governo que, a exemplo daqueles países, cuida em administrar, direta ou indiretamente, a escola à distância, atribuindo quase sempre papel central aos ministérios da Educação.

Considerando que o estímulo e o desenvolvimento da EAD também implicam na alocação de investimentos, o enunciado acima evoca outra característica da industrialização do ensino que, modo geral, acompanha a centralização administrativa - a concentração de capital. Muito embora não incida sobre todos os textos, já na sdr 10 encontramos dois fragmentos que aludem a essa concentração. Tanto em faltam recursos educacionais adequados como em pobreza de meios, percebemos uma referência, ainda que indireta e não exclusiva, ao papel do Estado como provedor essencial de recursos materiais e financeiros indisponíveis a uma parcela significativa da sociedade.

Além da década de 1950, a recorrência a um Estado provedor ou concentrador de recursos alcança os anos 1960. Mediante a sdr 9, observamos que uma das preocupações de então é oferecer alguma instrução formal para 
desistentes e para alunos que não têm recursos para instrução secundária. Apesar de mencionar os multi-bilhões de dólares de esfôrço espacial, numa alusão aos investimentos dos países desenvolvidos, a sdr 8 refere-se a um contexto em que os recursos se mostram limitados, exigindo sua maior concentração: custo baixo e com elevada confiabilidade; capabilidade de distribuir, a baixo custo; oportunidade universal de educação, no futuro próximo, a um custo razoável.

Recorrência semelhante à concentração de recursos dá-se durante os anos 1970. Por um lado, a sdr 7 reporta-se a dois projetos que parecem concentrar as dotações orçamentárias destinadas à política de EAD: Projeto Nacional de Teleducação ( $\left.N^{o} 36\right)$ e Projeto $N^{0} 7$. Por outro, encontramos em meio à sdr 6 dois enunciados que não deixam dúvida sobre o esforço de gerir os recursos a partir de projetos capazes de racionar as despesas e concentrar sua aplicação: qualificação de professores, à distância, sem retirá-los da sala de aula; o Projeto LOGOS I voltou-se para os estados da Paraíba e Piauí e territórios federais de Roraima, Rondônia e Amapá.

Igualmente à centralização administrativa, a concentração de recursos apresenta-se mais evidente durante os anos 1980. No entremeio da sdr 5, além do Sistema Nacional de Radiodifusão Educativa, encontramos referência à Fundação Centro Brasileiro de Televisão Educativa que tem coordenado as atividades no âmbito das tecnologias educacionais, concentrando os planos e a administração destas técnicas. Nos anos 1990, o sujeito do discurso volta a se referir à concentração de forma indireta. Enquanto na sdr 4, alude que a SENEB está fomentando ações junto as instituições governamentais e não-governamentais que constituem o Programa Nacional da Educação à Distância, indicando o controle daquele órgão sobre ações que podem envolver 
investimentos financeiros; na sdr 3, evoca o fato de que $o$ investimento que realizamos foi realmente pequeno, sugerindo o verbo realizamos a concentração de tal investimento junto ao próprio MEC.

$\mathrm{Na}$ linha da estratégia discursiva adotada no T1, encontramos na sdr 2 o seguinte fragmento, cuja intenção parece ser produzir como efeito de sentido uma espécie de desconcentração dos recursos destinados à política de EAD, nos anos 2000: A Secretaria de Educação a Distância, em sintonia com estados e municípios, vem, desde então, realizando investimentos significativos em uma infra-estrutura tecnológica. Apesar de indicar, à primeira vista, o incremento e uma maior distribuição dos investimentos entre as três esferas governamentais (tão evocadas na sdr 1), a assertiva não esconde, por outro lado, reportar-se ao conjunto da estrutura de governo responsável pela concentração dos recursos públicos.

Em decorrência inclusive da concentração dos recursos, centralização administrativa e produção de massa, três outras características da industrialização do ensino afetam conjuntamente o corpus discursivo - formalização, padronização e objetivação. Antecedendo sua ocorrência expressiva junto ao T1, logo observamos no entremeio da sdr 2 um grupo de fragmentos que se reportam à formalização das ações em EAD: politica; programas; projeto; Projeto Ipê; programa de atualização dos professores ingleses; programação de alta qualidade. Estes dois últimos, por sinal, fazem alusão à padronização de tais ações, buscada muitas vezes em padrões estrangeiros. Quando associado ao enunciado realizando investimentos significativos em uma infra-estrutura tecnológica, o conjunto dos fragmentos acaba reforçando a incidência da objetivação dos processos de ensino e aprendizagem, nos anos 2000. 
Objetivação, padronização e formalização fazem-se mais presentes, ainda, durante os anos 1990. Aludindo fragmentos como programas, lançarmos a idéia de criar esse programa, programa de treinamento de professores e lançado esse programa, a sdr 3 não apenas se reporta a um processo de objetivação, como também de formalização, principalmente, quando levamos em conta também o enunciado relatório do Nepp. A padronização é evocada, por sua vez, através de fragmentos como Seminário Internacional, sucesso, $100 \%$ de audiência e $100 \%$ de utilização, aceitação plena e imediata que remetem a padrões de qualidade norteadores daqueles programas.

A alusão a tais características é mais intensa quando consideramos a sdr 4, onde a incidência de cada uma delas parece se dar concomitantemente às demais: Programa Nacional da Educação à Distância; Programa UM SALTO PARA O FUTURO; Projeto Professor Alfabetizador; Projeto Complementação Pedagógica; Projeto Alfabetizar é Construir; Projeto Sistema de Apoio Tecnológico à Educação; programas de interesse do setor educacional; projetos de teleducação-telemática. A reiteração de projeto e programa não deixa dúvida sobre o grau elevado de formalização e objetivação das ações vinculadas à política de EAD, cujo processo de padronização é acentuado pelos enunciados Sistema de Apoio Tecnológico à Educação, Rede Brasil e rede de escolas equipadas que referem estruturas concebidas de acordo com padrões consideráveis de uniformidade.

Vestígio significativo de que essa padronização já afeta a política de EAD, nos anos 1980, é o enunciado concentrando os planos e a administração destas técnicas dispersos até 1982. Associando a este os fragmentos Sistema Nacional de Radiodifusão Educativa e recepção organizada, vamos perceber que tal política é estruturada uniformemente, desde 
a esfera macro do Sistema até a esfera micro da recepção. Além disso, na sdr 5, encontramos ao mesmo tempo traços de formalização e objetivação nos fragmentos política de estímulo e programas que reforçam a idéia de desenvolver a EAD a partir de estruturas capazes de manter a formalidade e objetividade necessárias a sua reprodução em larga escala.

Essa idéia, no entanto, já prevalece ao longo dos anos 1970. A sdr 6é atravessada por alusões não só aos processos de formalização e padronização - $\underline{\text { Projeto } L O G O S ~ I, ~ p r o j e t o, ~}$ assim como de objetivação: metodologia e técnica de ensino-aprendizagem para qualificação de professores, à distância. Contudo, além da objetivação se fazer presente mediante o enunciado utilização das tecnologias educacionais, evoca a sdr 7 uma profusão de fragmentos que demonstram que o sujeito do discurso encontra-se fortemente afetado pelas idéias da padronização e da formalização: projetos prioritários do Plano Setorial de Educação e Cultura 1972/74; Projeto Nacional de Teleducação (No 36); Plano Setorial 1975/79; política de educação; novo Plano Setorial para 1975/79; Projeto $N^{\circ}$ 36; Projeto No 7; estruturas para e pluri-escolares; estrutura mais aberta e flexível. O que implica supor que este último enunciado dá conta muito mais de uma estratégia discursiva do que de uma estrutura potencialmente aberta ou flexível.

Nos anos 1960, a recorrência a essas três características do processo industrial apresenta-se mais evidente. A ênfase da sdr 8 recai sobre a formalização e padronização, representadas por intermédio dos seguintes fragmentos: programa; programa Apollo; estruturação de um programa; Projeto SACI; iniciou um estudo e, em 1967, propôs medidas; relatório de 3 volumes descrevendo o Projeto SACI; Tal relatório resumia os estudos da CNAE; O presente relatório descreve 
a evolução desde maio de 1968 e esboça a seqüência de passos. De alguma forma, retoma aquela seqüência alusões feitas pela sdr 9 que, ao se referir a o plano educacional deve proporcionar um programa devidamente equilibrado e melhor organização e mais homogeneidade no sistema de educação, reforça a idéia de uma política de EAD estruturada de forma programática e homogênea.

Através do enunciado categórico a instrução gravada, bem preparada, pode ensinar ampla gama de matérias tão eficientemente quanto um professor, a sdr 8 também retoma a ênfase sobre a objetivação que, particularmente, marca a sdr 9: novos meios tecnológicos para fins educacionais; Programas de TVE pelos professôres mais talentosos e mais preparados, suplementariam a apresentação da matéria essencial dada pelos professôres de classe; a instrução por TV tem se mostrado da maior eficiência; treinamento de professôres ou instrutores; uso de guias, de observação do ensino por parte dos selecionados professôres de televisão; melhorar os métodos de instrução. Quando adicionamos a esses fragmentos o enunciado A eficiência de ensino deve ser aperfeiçoada por quaisquer meios possíveis, entendemos por que o sujeito do discurso não faz qualquer referência ao fato de que essa melhoria se dá em detrimento da perda de subjetividade no processo de ensino-aprendizagem.

Esses traços de objetivação, todavia, são remanescentes dos anos 1950. Analisando a sdr 10, observamos uma gama de fragmentos e enunciados que reiteram a idéia de tornar o processo de ensino-aprendizagem, cada vez mais, racional e objetivo: poderoso e eficiente meio; não podem estar presentes aos cursos tradicionais; faltam recursos educacionais adequados; pobreza de meios; por um motivo ou outro, não podem ir à escola; importantíssimo e eficaz instrumento, que não pode ser abandonado e que cumpre, muito pelo contrário, estimular e desenvolver. 
Os verbos estimular e desenvolver produzem como efeito de sentido, inclusive, a idéia de formalização de uma ação, voltada para equacionar tais necessidades ou demandas educacionais. Por seu turno, o fragmento a seguir indica a presença de vestígios de padronização: Graças a êle, em numerosas regiões do globo, como sejam, entre outras, os Estados Unidos e a Rússia, a Inglaterra e a Commonwealth, a França e a Alemanha, os Países Escandinavos e o Japão, milhões e milhões de pessoas, anualmente, iniciam e prosseguem estudos. Os nomes próprios aí mencionados reportam-se, justamente, a países cujos sistemas são considerados referência em relação aquilo que os alemães chamam de "escola à distância" (Fernschule), padrão que o Brasil vai alcançar, segundo a sdr 1 , cinco décadas depois.

Paralelamente à padronização, formalização e objetivação, outra característica da industrialização do ensino incide sobre o corpus discursivo - os métodos de controle científicos. Já durante os anos 1950, traços de sua ocorrência marcam a sdr 10: em numerosas regiões do globo; milhões e milhões de pessoas; não podem estar presentes aos cursos tradicionais; freqüentar escolas ou centros de treinamento; por um motivo ou outro, não podem ir à escola; reduzida densidade demográfica; escassez de tempo; faltam recursos educacionais adequados; pobreza de meios. Ao se referir a dados estatísticos e indicadores sócio-econômicos evoca o sujeito do discurso a idéia de conferir a este maior credibilidade, sobretudo, a partir de critérios e procedimentos de natureza científica.

A recorrência aos métodos científicos é mais incisiva, ainda, durante os anos 1960. Na sdr 9, observamos um sujeito do discurso fazendo questão de se reportar a uma série de indicadores que reforçam seus argumentos: desistentes; impacto total; Beneficios indiretos; Capacidade de 
ensino; eficiência de ensino; Melhoria da qualidade de instrução; a instrução por TV tem se mostrado da maior eficiência. Este último enunciado é reatualizado logo depois, em meio à sdr 8 , através da paráfrase $a$ instrução gravada, bem preparada, pode ensinar ampla gama de matérias tão eficientemente quan to um professor, pressupondo se tratar de uma inferência ou conclusão derivada de algum trabalho de pesquisa.

Além de mencionar outros indicadores (elevada confiabilidade, capabilidade de distribuir, Outra decorrência) e estatísticas (multi-bilhões de dólares de esfôrço espacial, Mais de um milhar de comparações), a sdr 8 faz referências diretas aos métodos de controle científicos. Enquanto na sdr 9 encontramos os enunciados observação do ensino por parte dos selecionados professores de televisão e melhorar os métodos de instrução, na sdr 8 chama-nos a atenção uma abundância de fragmentos nesse sentido, tais como: métodos de organização e de gerência; de pesquisa pura e aplicada e de inovação no desenvolvimento econômico e social; Tal relatório resumia os estudos da CNAE, durante dois anos, para avaliar as aplicações da tecnologia espacial à educação e às comunicações no contexto brasileiro.

Examinando os textos referentes aos anos 1970, a impressão que se tem é que o corpus discursivo, cada vez mais, apresenta vestígios daqueles métodos. A sdr 7 é marcada não só por alusões a indicadores do tipo fatores determinantes, maior eficácia operativa e oportunidades de formação segundo suas capacidades, como notadamente pelo seguinte fragmento: Com o novo Plano Setorial para 1975/79, extingue-se o Projeto $N^{o} 36$, substituído pelo Projeto $N^{o} 7$ que objetiva o Desenvolvimento de Novos Processos e Metodologias Educacionais. Considerando que, assim como Metodologias, Processos também remetem a procedimentos, o que depreendemos daí é que o Projeto $N^{0} 7$ submete, por excelência, 
o Projeto $N^{0} 36$ (Projeto Nacional de Teleducação) a métodos de controle científicos.

Maiores evidências, contudo, vamos encontrar em meio à sdr 6, começando pelas recorrentes alusões a dados e indicadores: nível de escolarização da clientela; Desde 1972 o DSU/MEC diagnosticou cerca de 150 a 200 mil professores leigos; alto indice de professores leigos; dificuldades de comunicação, acesso e infra-estrutura; eficiência. Essa ênfase torna-se mais acentuada, ainda, à medida que o sujeito do discurso faz referência a procedimentos metodológicos, inclusive, de cunho experimental: critério de escolha; Selecionadas as áreas para atuação; experimento da metodologia e técnica; testando, através do Projeto LOGOS I, metodologia e técnica de ensino-aprendizagem. Como se o referido projeto pudesse ser comparado a um laboratório de pesquisa em qualificação de professores, à distância.

Dois enunciados da sdr 5 indicam que essa concepção se mantém, também, nos anos 1980: As estações de televisão educativa atingem, atualmente, 300 municípios em todo o País, com audiência estimada de 32 milhões de pessoas e Todo esse trabalho vem sendo articulado com as secretarias estaduais e municipais de educação, para fins de recepção organizada. Associando o primeiro a outros fragmentos (significativos resultados; A consolidação, o aperfeiçoamento e a expansão; o fortalecimento e o aperfeiçoamento), percebemos como o sujeito do discurso continua a dar ênfase a indicadores e dados estatísticos. Correlacionando agora o primeiro ao segundo enunciado, vamos notar que recepção organizada alude ao monitoramento senão da audiência potencial de 32 milhões de pessoas, pelo menos, dos estudantes e professores da rede estadual e municipal de ensino, impossível de ser efetivado sem o concurso de métodos de controle científicos. 
Os indicadores e as estatísticas afetam significativamente o discurso em torno da política de EAD, durante os anos 1990. A referência aos primeiros é exemplar em se tratando da sdr 4: As dimensões continentais do Brasil, as enormes demandas em termos de capacitação da força de trabatho nacional, em especial dos professores da educação básica e o potencial das novas tecnologias; Considerando esses indicadores. Paralelamente às alusões a estes, tais como sucesso, $o$ fracasso e o desperdício, aceitação plena e imediata, as estatísticas pontuam a sdr 3: atinge 50 mil escolas; $100 \%$ de audiência e 100\% de utilização.

Marca as duas seqüências, muito mais ainda, a reiteração de alguns termos e expressões do mundo acadêmico-científico que evocam, quase que automaticamente, aqueles métodos de controle. Enquanto, na sdr 4, encontramos fragmentos que referem $o$ desenvolvimento de estudos e pesquisas na área de teleducação, o desenvolvimento de projetos de teleducação-telemática e o intercâmbio do conhecimento acadêmico na área nacional e internacional, na sdr 3 observamos os enunciados programa de treinamento de professores e operação experimental da TV Escola que retomam uma idéia cara à sdr 6, concebendo os projetos em EAD nos moldes de um laboratório de pesquisa. $\mathrm{O}$ sujeito do discurso, por sinal, destina todo um segmento da sdr 3 para acentuar o fato de a TV Escola encontrar-se submetida ao monitoramento científico, enfatizando: Quero chamar a atenção para o fato de que, além de termos lançado esse programa, tivemos a coragem de submetê-lo à avaliação independente externa: a Universidade Estadual de Campinas, através do Núcleo de Estudos de Políticas Públicas - Nepp.

Três enunciados da sdr 2 voltam a relacionar a TV Escola à pesquisa experimental, nos anos 2000: O projeto foi inspirado em duas experiências; "Projeto Ipê" transmitido 
pela TV Cultura; programa de atualização dos professores ingleses realizado pela BBC. Quando acrescentamos a isso a referência por parte da sdr 1 ao forte incentivo à pesquisa para o setor constituir uma das ações que conferem caráter estratégico à SEED, depreendemos que o discurso em torno da política de EAD é decisivamente afetado pela recorrência aos métodos de controle científicos, aos quais estão vinculadas outras características importantes à industrialização do ensino - trabalho preparatório, planejamento e organização, cujos vestígios no corpus discursivo podem ser examinados conjuntamente.

Tais características são evocadas, inclusive, quando a sdr 2 reporta-se àquelas duas experiências que inspiram a TV Escola. Ao referir que o "Projeto Ipê" foi desenvolvido pela Secretaria de Educação de São Paulo de 1984 a 1986, quando o atual ministro ocupou a pasta estadual e que o programa de atualização dos professores ingleses teria sido apresentado aos dirigentes do Ministério em visita à Inglaterra em 1995, o sujeito do discurso faz alusão não só ao trabalho preparatório (experiência desenvolvida de 1984 a 1986), como também ao planejamento (visita à Inglaterra em 1995) e à organização da política de EAD (pasta estadual, dirigentes do Ministério). Mas outros vestígios dessas características marcam, incisivamente, a sdr 2: estrutura de governo, Ministério da Educação, SEED, escola pública, ensino básico (que remetem à organização); importantes ações, política, projeto, programas, objetivos, programação de alta qualidade (que aludem ao planejamento); e A Secretaria de Educação a Distância, em sintonia com estados e municípios, vem, desde então, realizando investimentos significativos em uma infra-estrutura tecnológica que concerne, ao mesmo tempo, à organização, planejamento e trabalho preparatório. 
Nos anos 1990, observamos indícios do trabalho preparatório, sobretudo, na sdr 3: operação experimental da TV Escola; primeiro ano; dois anos de funcionamento da TV Escola; dois anos e meio. Enquanto na mesma sequência as referências ao Ministério da Educação e 50 mil escolas lembram-nos o princípio da organização, as alusões a esta na sdr 4 vão desde SENEB e rede de escolas até a articulação dos órgãos governamentais e não-governamentais. O planejamento, porém, é a característica que mais afeta o sujeito do discurso, nesse período. Seja através dos seguintes fragmentos da sdr 3: programas; lançamos; lançarmos a idéia de criar esse programa; lançado esse programa; programa de treinamento de professores; investimento que realizamos; beneficios que esperávamos alcançar e que alcançamos. Seja mediante uma série de ocorrências da sdr 4, tais como: Programa Nacional da Educação à Distância; Projeto Professor Alfabetizador, Projeto Complementação Pedagógica Projeto Alfabetizar é Construir, Projeto Sistema de Apoio Tecnológico à Educação e demais programas educativos.

O sujeito do discurso da sdr 5, também, não deixa de ser afetado pelo princípio do planejamento, como demonstram os seguintes vestígios: política de estímulo; programas; desenvolvimento de ações; criação; A consolidação, o aperfeiçoamento e a expansão; significativos resultados. Além de sugerir um sujeito influenciado pelo trabalho preparatório, os fragmentos que transcrevemos a seguir revelam um discurso que nos anos 1980 confere maior ênfase, todavia, ao processo de organização da política de EAD: A Fundação Centro Brasileiro de Televisão Educativa, criada pela Lei $n^{0} 5.198 / 67$, tem coordenado as atividades no âmbito das tecnologias educacionais, concentrando os planos e a administração destas técnicas; A criação do Sistema Nacional de Radiodifusão Educativa, integrado hoje por 14 emissoras de 
televisão, 340 repetidoras de televisão e 22 emissoras de rádio educativas, contribuiu decisivamente para o fortalecimento e o aperfeiçoamento da teleducação brasileira.

Organização e trabalho preparatório são duas características que, também, incidem conjuntamente em meio à sdr 6: Desde 1972 o DSU/MEC diagnosticou cerca de 150 a 200 mil professores leigos; O Departamento resolveu então partir para uma ação supletiva na tentativa de resolução do problema, testando, através do Projeto LOGOS I, metodologia e técnica de ensino-aprendizagem para qualificação de professores, à distância, sem retirá-los da sala de aula, num processo de 12 meses, a nível de $1^{0}$ grau. Atravessando a seqüência, encontramos ainda enunciados como programa específico em desenvolvimento, projeto, principal objetivo e eficiência que referem pistas da ocorrência do planejamento.

Refletindo, muito mais, a incidência da planificação de modo geral junto ao Regime Militar, nos anos 1970, a sdr 7 apresenta a um só tempo traços daquelas três características. Mantendo forte interdependência entre elas, o sujeito do discurso reporta-se aos princípios da organização, planejamento e trabalho preparatório, muitas vezes, de forma justaposta ou sobreposta, como ilustram exemplarmente os seguintes fragmentos: Foram estes os motivos que levaram o MEC a incluir, entre os projetos prioritários do Plano Setorial de Educação e Cultura 1972/74, o Projeto Nacional de Teleducação ( $\left.N^{o} 36\right)$, com o objetivo de coordenar, integrar e sistematizar a utilização das tecnologias educacionais; Com o novo Plano Setorial para 1975/79, extingue-se o Projeto $N^{o} 36$, substituído pelo Projeto $N^{o} 7$ que objetiva o Desenvolvimento de Novos Processos e Metodologias Educacionais, que hão de fazer da escola do futuro uma estrutura mais aberta e flexível.

Nos anos 1960, já observamos pistas dessa ocorrência e interdependência entre as três características. Enquanto 
o planejamento afeta a sdr 8 mediante enunciados, tais como, programa, esforços espaciais tipo programa Apollo, sub-produto dos multi-bilhões de dólares de esfôrço espacial, insumos úteis, custo baixo e com elevada confiabilidade, capabilidade de distribuir, a baixo custo; encontramos indícios do princípio da organização nos seguintes fragmentos: métodos de organização e de gerência; estruturação de um programa; Em 1966 a Comissão Nacional de Atividades Espaciais (CNAE) iniciou um estudo e, em 1967, propôs medidas a serem tomadas pelo Conselho Nacional de Pesquisas visando a uma solução para o problema educacional do país.

Correlacionando este último fragmento a outros que ainda perpassam a sdr 8, constatamos também a presença do trabalho preparatório: quatro elementos que, em conjunto, fornecem a base; relatório de 3 volumes descrevendo o Projeto SACI; Tal relatório resumia os estudos da CNAE, durante dois anos, para avaliar as aplicações da tecnologia espacial à educação $e$ às comunicações no contexto brasileiro. Além disso, reflete o discurso a incidência conjunta do trabalho preparatório e do planejamento: O presente relatório descreve a evolução desde maio de 1968 e esboça a seqüência de passos, entre as alternativas mais promissoras que poderão tornar o Brasil capaz de usufruir as vantagens de oportunidade universal de educação, no futuro próximo, a um custo razoável.

A organização e o trabalho preparatório não deixam de ser evocados na sdr 9. Enquanto o argumento melhor organização e mais homogeneidade no sistema de educação com maior participação da comunidade reporta-se à primeira característica, enunciados como treinamento de professôres ou instrutores, treinamento em serviço via TVE e professôres parcialmente treinados, embora se refiram a ações ainda a serem desenvolvidas, remetem à segunda característica. Mesmo assim, são os indícios da presença do planejamento 
que ganham relevo junto àquela seqüência: o plano educacional deve proporcionar um programa devidamente equilibrado; Programas de TVE; rápido desenvolvimento; Capacidade de ensino; impacto total; Benefícios indiretos.

Os indícios do planejamento afetam o sujeito do discurso desde os anos 1950. Na sdr 10, observamos sua presença em enunciados que vão da escassez de tempo, faltam recursos educacionais adequados, pobreza de meios e reduzida densidade demográfica até por um motivo ou outro, não podem ir à escola. Além disso, encontramos vestígios do planejamento concomitantemente a traços do princípio da organização em fragmentos como aplicados conjugadamente; poderoso e eficiente meio; importantíssimo e eficaz instrumento, que não pode ser abandonado e que cumpre, muito pelo contrário, estimular e desenvolver. Contudo, a ênfase do sujeito do discurso sobre um trabalho preparatório desenvolvido há longo tempo e em outros países parece ainda mais expressiva: $O$ ensino por correspondência, que surgiu há um século, vem sendo amplamente utilizado; É, aliás, sobretudo como instrumento de educação e treinamento de adultos que o ensino por correspondência tem sido encarado na maioria dos países em que vem florescendo; a sua utilização também, por incrivel que possa parecer à primeira vista, em instrução do nível de jardim da infância.

Vários fragmentos acima referidos chamam-nos a atenção para a forte incidência de outra característica da industrialização do ensino sobre o discurso em torno da política de EAD - a mecanização. Num primeiro momento, sua ocorrência na sdr 10 se dá de forma indireta, através de enunciados como pobreza de meios, poderoso e eficiente meio de educação e treinamento, importantíssimo e eficaz instrumento e recursos educacionais adequados. Num segundo momento, sua emergência ocorre de forma 
direta, mediante referências tais como ensino por correspondência; é que a escola vai, sob a forma de ensino por correspondência; ensino pelo rádio e pela televisão; o que os alemães chamam de "escola à distância" (Fernschule).

A recorrência à mecanização prevalece nos anos 1960. A maioria das referências da sdr 9, nesse sentido, diz respeito diretamente à tecnologia educacional, incluindo desde novos meios tecnológicos para fins educacionais, satélite e televisão educativa por satélites até Programas de TVE, instrução por TV e uso de TV. Ainda assim, seja direta seja indiretamente, a sdr 8 é ainda mais afetada pelo princípio da mecanização: adiantamento da tecnologia eletrônica; Satélite geoestacionário (síncrono); tecnologias avançadas; Projeto SACI (Satélite Avançado de Comunicações Interdisciplinares, isto é, educação e comunicações); aplicações da tecnologia espacial à educação e às comunicações; instrução pelo rádio e televisão.

Nos anos 1970, embora não seja tão enfático quanto na década anterior, o sujeito do discurso volta a se reportar à mecanização. Através da sdr 7 , alude ele ao Projeto Nacional de Teleducação, à utilização das tecnologias educacionais e ao recurso de estruturas para e pluri-escolares e com diferentes tipos de inovação, proporcionados pelas tecnologias educacionais. Mediante a sdr 6, além de se referir às dificuldades de comunicação, acesso e infra-estrutura, faz questão de acentuar aquele sujeito a metodologia e técnica de ensino-aprendizagem para qualificação de professores, à distância. Conforme vimos anteriormente, este enunciado vai ser retomado e reatualizado, mais adiante, de forma incisiva pelo T1.

A consolidação, o aperfeiçoamento e a expansão da televisão e do rádio educativos não deixam dúvida sobre a prevalência da mecanização, também, durante os anos 1980. Além disso, outros fragmentos referenciam a sua forte presença 
em meio a sdr 5: uso de novas tecnologias na área da educação; tecnologias educacionais; Sistema Nacional de Radiodifusão Educativa; 14 emissoras de televisão, 340 repetidoras de televisão e 22 emissoras de rádio educativas; estações de televisão educativa; teleducação brasileira. Mesmo de forma indireta, os termos técnicas, programas e audiência constituem ainda marcas do princípio da mecanização junto àquela sequência.

Esses vestígios da mecanização voltam a se fazer presentes ao longo dos anos 1990. Enquanto na sdr 4, encontramos enunciados como veiculação de mensagens (flashes) e programas, programas educativos e rede de escolas equipadas, a sdr 3 é atravessada por termos e expressões como transmissões, equipamentos, canal de satélites brasileiro e meios de comunicação. Além de fazer referência à tecnologia em geral - progresso técnico, novas tecnologias, recursos tecnológicos disponíveis, a sdr 4 atribui importância sobretudo à tecnologia educacional: educação à distância; Projeto Sistema de Apoio Tecnológico à Educação; TVE-RJ Rede Brasil e outras emissoras de rádio e televisão; reequipamento das TVEs; área de teleducação; teleducação-telemática.

Em se tratando da sdr 3, essa importância é atribuída à $T V$ Escola que parece sintetizar, nesse período, toda uma ênfase do sujeito do discurso sobre a tecnologia. Na sdr 2, a TV Escola volta a se destacar em meio a outros fragmentos que apontam para a recorrência ao princípio da mecanização. Se, por um lado, observamos referências como BBC e "Projeto Ipê" transmitido pela TV Cultura, por outro, vamos encontrar enunciados como novas ferramentas, novos instrumentos e novas tecnologias, infra-estrutura tecnológica, exclusão tecnológica e educação a distância. Este último, por sinal, ganha relevância crescente nos anos 2000, sendo referido por cinco vezes na sdr 1 , ao lado de 
outras recorrências, tais como, utilização intensiva das tecnologias de informação e comunicação; inovações tecnológicas e metodológicas; tecnologias educacionais; TV Escola e Proinfo; Sistema Universidade Aberta do Brasil.

A influência da mecanização sobre o discurso em torno da política de EAD pressupõe a incidência, concomitantemente, de outras características fundamentais à industrialização do ensino - divisão de trabalho, linhas de montagem, mudança de função/especialização. Sintomático nesse sentido é o fato de, igualmente à sdr 1, a Secretaria de Educação a Distância ocupar lugar de destaque na sdr 2, como estrutura de governo, vinculada ao Ministério da Educação, especialmente dedicada ao tema da EAD, o que implica especialização por excelência. Ainda relacionados a esta, encontramos os enunciados aperfeiçoamento e capacitação de professores do ensino básico e programa de atualização dos professores, cujo papel na divisão de trabalho aí evocada demonstra ser secundário e diferente, portanto, daquele reservado aos dirigentes do Ministério. Do mesmo modo, são secundários os lugares assumidos pelos estados e municípios, pasta estadual, Secretaria de Educação de São Paulo, escola pública e sala de aula que, no entanto, formam com a SEED uma linha de montagem em torno de programas de EAD.

Essa cadeia produtiva apresenta-se mais extensiva, ainda, durante os anos 1990. Se, na sdr 3, observamos seus indícios através de referências como meios de comunicação, escolas e professores, na sdr 4, encontramos uma diversidade de alusões à linha de montagem que envolve a política de EAD, destacando-se as seguintes: órgãos governamentais e não-governamentais; Unidades Federadas; Fundação Roquette Pinto/TVE-RJ Rede Brasil; escolas equipadas; clientela do ensino fundamental: alunos, professores e gestores. Refletem 
ambas as cadeias uma divisão de trabalho que seria comandada, respectivamente, pelo Ministério da Educação e $S E N E B$ e que implicaria um processo de especialização representado, no caso da sdr 3, mediante referências como Universidade Estadual de Campinas, através do Núcleo de Estudos de Políticas Públicas - Nepp e, no caso da sdr 4, por intermédio de fragmentos como Projeto Professor Alfabetizador, Projeto Complementação Pedagógica, Projeto Alfabetizar é Construir, Projeto Sistema de Apoio Tecnológico à Educação.

Os enunciados programas para formação e reciclagem de professores, secretarias estaduais e municipais de educação e recepção organizada, que pressupõem gestores, professores e tutores especialistas em EAD, são exemplares no sentido de percebermos vestígios do princípio da especialização nos anos 1980. Além da referência à Fundação Centro Brasileiro de Televisão Educativa, o fragmento Sistema Nacional de Radiodifusão Educativa, integrado hoje por 14 emissoras de televisão, 340 repetidoras de televisão e 22 emissoras de rádio educativas é mais significativo ainda de que a ênfase da sdr 5 reside na divisão de trabalho e nas linhas de montagem. Traços dessas características são encontrados, ademais, em estações de televisão educativa, 300 municípios em todo o País, 32 milhões de pessoas, pré-escolar, Supletivo de $1^{\circ}$ e $2^{\circ}$ graus.

Apesar de evocar o princípio da especialização, através de enunciados como cerca de 150 a 200 mil professores leigos e formação segundo suas capacidades presentes, respectivamente, na sdr 6 e sdr 7, a ênfase do sujeito do discurso nos anos 1970 se volta, também, para a divisão de trabalho e as linhas de montagem. Na sdr 6, a recorrência a essas características vai desde a importância atribuída primariamente à $D S U / M E C$ e secundariamente a estados 
da Paraíba e Piauí e territórios federais de Roraima, Rondônia e Amapá, até termos e expressões como unidades, quatro primeiras séries do ensino de $1^{\circ}$ grau e clientela. Além dos fragmentos Plano Setorial de Educação e Cultura 1972/74, Plano Setorial 1975/79 e Projeto Nacional de Teleducação, encontramos a ocorrência de ambas as características na sdr 7 no destaque dado ao Ministério da Educação e Cultura e nas referências à política de educação, sistema educativo, estruturas para e pluri-escolares.

Conselho Nacional de Pesquisas, Comissão Nacional de Atividades Espaciais (CNAE) e Projeto SACI constituem enunciados da sdr 8 que não se reportam apenas à divisão de trabalho, como também ao princípio da especialização. Bastante associados aos mesmos, observamos ainda indícios que remetem às linhas de montagem - instrução pelo rádio e televisão, escolas de todo o Brasil, sala de aula, professor. Na sdr 9, todavia, este último aparece em meio a uma série de alusões à especialização: professôres ou instrutores, professôres mais talentosos e mais preparados, selecionados professôres de televisão, professôres parcialmente treinados. Já os vestígios da divisão de trabalho e da linha de montagem podem ser encontrados junto aos seguintes fragmentos: sistema de educação; televisão educativa; áreas rurais; professôres; estudantes; alfabetização de adultos; sala de aula.

Examinando a sdr 10, vamos notar que as alusões à divisão de trabalho já se apresentam bastante correlacionadas à evocação às linhas de montagem. São vários os indícios da ocorrência simultânea dessas características, nos anos 1950: pelo rádio e pela televisão; jardim da infância; escolas; residentes da zona rural ou de pequenas localidades; diversos outros grupos (donas de casa, incorporados às forças armadas para a prestação do serviço militar, presidiários e reclusos, de modo geral). São significativos, também, os 
enunciados que invocam o princípio da especialização centros de treinamento; aperfeiçoamento profissional; empregados de todos os tipos e categorias (funcionários, comerciários, bancários, industriarios, etc), antecipando a ênfase, retomada nos anos 2000, relativamente ao aperfeiçoamento $e$ capacitação e à formação continuada ao longo da vida.

Os anos 1950 antecipam, muito mais ainda, uma característica da industrialização do ensino que marca, profundamente, todo o discurso em torno da política de EAD - a racionalização. Seus vestígios podem ser encontrados na sdr 10, de modo especial, em enunciados que fazem alusão à eficiência e à eficácia da educação a distância: amplamente utilizado, em nossos dias, como poderoso e eficiente meio de educação e treinamento; importantíssimo e eficaz instrumento, que não pode ser abandonado e que cumpre, muito pelo contrário, estimular e desenvolver. A recorrência à racionalização, entretanto, atravessa praticamente toda a sdr 10, mediante uma série de fragmentos que enaltecem os impactos sócio-culturais da EAD, destacando-se os seguintes: milhões e milhões de pessoas, anualmente, iniciam e prosseguem estudos, que, por outra forma, thes teriam sido muito penosos ou impossiveis de fazer; de residentes da zona rural ou de pequenas localidades, a que faltam recursos educacionais adequados, em virtude da pobreza de meios e da reduzida densidade demográfica, inerentes à situação.

Os indícios da racionalização continuam substancialmente presentes nos anos 1960, logo se sobressaindo as alusões que apontam para os impactos da EAD sobre as nações. Na sdr 9, são exemplares nesse sentido os seguintes fragmentos: A fim de produzir um impacto total em uma nação, o plano educacional deve proporcionar um programa devidamente equilibrado capaz de convencer a todos os indivíduos a dar sua máxima contribuição à sociedade; a televisão 
educativa por satélites é o avanço mais arrojado de que se dispõe para ajudar a impelir as nações em desenvolvimento para a era da educação e da alfabetização universais. A sdr 8, também, é marcada por uma alusão expressiva nessa direção: quatro elementos que, em conjunto, fornecem a base para um programa que poderia, ràpidamente, colocar o Brasil entre as nações líderes nos campos de oportunidade educacional, de pesquisa pura e aplicada e de inovação no desenvolvimento econômico e social.

As referências aos princípios da inovação e da eficiência, por sinal, ajudam a evocar a racionalização. Enquanto na sdr 9 as encontramos nos enunciados A eficiência de ensino deve ser aperfeiçoada por quaisquer meios possíveis, a instrução por TV tem se mostrado da maior eficiência e proporcionar inovações na estrutura social, na sdr 8 as observamos em Mais de um milhar de comparações de instrução convencional de sala de aula com a instrução pelo rádio e televisão, não deixam dúvidas de que a instrução gravada, bem preparada, pode ensinar ampla gama de matérias tão eficientemente quanto um professor.

A relação custo-benefício é outro princípio racional evocado, nesse período. Seja através da sdr 9: Benefícios indiretos. A TVE pode proporcionar melhor organização e mais homogeneidade no sistema de educação com maior participação da comunidade no referido sistema. Seja, muito mais ainda, por intermédio da sdr 8: Como sub-produto dos multi-bilhões de dólares de esfôrço espacial, o adiantamento da tecnologia eletrônica pode colocar, por custo baixo e com elevada confiabilidade, auxílios eletrônicos a educação que podem vir a ser usados nas escolas de todo o Brasil; alternativas mais promissoras que poderão tornar o Brasil capaz de usufruir as vantagens de oportunidade universal de educação, no futuro próximo, a um custo razoável. 
Em meio à sdr 9, destacam-se ainda uma série de vestígios alusivos ao princípio da eficácia: Melhoria da qualidade de instrução. Programas de TVE pelos professôres mais talentosos e mais preparados, suplementariam a apresentação da matéria essencial dada pelos professôres de classe; Capacidade de ensino. O uso de TV com professôres parcialmente treinados aumentará grandemente o número de estudantes a receberem boa educação, especialmente em áreas rurais. Representando como que uma síntese da prevalência dos princípios da inovação, eficiência, eficácia e custo-benefício, encontramos na sdr 8 o seguinte fragmento: Outra decorrência dos esforços espaciais tipo programa Apollo são os métodos de organização e de gerência que podem fornecer insumos úteis para a estruturação de um programa brasileiro destinado a aplicar tecnologias avançadas para proporcionar universal oportunidade de educação no Brasil inteiro.

Sinônimos da racionalização, esses princípios voltam a afetar o discurso em torno da política de EAD nos anos 1970. Além de enunciados como coordenar, integrar e sistematizar a utilização das tecnologias educacionais, com vistas à universalização do ensino aludirem a uma ação racional, os princípios da inovação e da eficácia acometem a sdr 7 através de dois fragmentos: Com o novo Plano Setorial para 1975/79, extingue-se o Projeto $N^{0} 36$, substituído pelo Projeto $N^{o} 7$ que objetiva o Desenvolvimento de Novos Processos e Metodologias Educacionais, que hão de fazer da escola do futuro uma estrutura mais aberta e flexivel, oferecendo a todos oportunidades de formação segundo suas capacidades; será necessário conferir à educação maior eficácia operativa, com o recurso de estruturas para e pluri-escolares e com diferentes tipos de inovação, proporcionados pelas tecnologias educacionais.

Ênfase por parte da sdr 7 tende a receber, também, o princípio da eficiência, cujos vestígios encontram-se 
bastante atrelados ao discurso em torno do desenvolvimento nacional (retomado, nos anos 2000, por intermédio do T1): engajar e articular a educação ao processo de desenvolvimento do País, de modo intrínseco, não deixando que ela permaneça apenas a reboque desse desenvolvimento; o MEC situa a educação como integrada ao desenvolvimento, como um dos seus fatores determinantes e por ele condicionada, na consecução de suas finalidades essenciais; estreitar o liame entre a política de educação e o esforço de desenvolvimento e democratizar o sistema educativo, orientando-o no sentido de contribuir para a correção das injustiças e discriminações.

Marcas da eficiência se fazem presentes, também, em meio à sdr 6: O projeto restringiu-se à qualificação, embora a habilitação fosse ideal, tendo em vista o nível de escolarização da clientela, que presumivelmente não teria condições de atingir eficiência através de estudos a nível de $2^{\circ}$ grau, o que forçosamente interferiria no experimento da metodologia e técnica. Contudo, são os indícios da relação custo-benefício que se apresentam de forma ainda mais incisiva junto àquela seqüência: $O$ Departamento resolveu então partir para uma ação supletiva na tentativa de resolução do problema, testando, através do Projeto LOGOS I, metodologia e técnica de ensino-aprendizagem para qualificação de professores, à distância, sem retirá-los da sala de aula; O critério de escolha dessas unidades deveu-se ao alto indice de professores leigos existentes nesses locais e em face das dificuldades de comunicação, acesso e infra-estrutura, o que se prestava mais propriamente para o experimento, pelas dificuldades.

Dois fragmentos da sdr 5, por sua vez, completam-se para reiterar a alusão aos princípios da eficiência e da eficácia: A consolidação, o aperfeiçoamento e a expansão da televisão e do rádio educativos representam significativos resultados da política de estímulo ao uso de novas tecnologias na área da 
educação; e A criação do Sistema Nacional de Radiodifusão Educativa, integrado hoje por 14 emissoras de televisão, 340 repetidoras de televisão e 22 emissoras de rádio educativas, contribuiu decisivamente para o fortalecimento e o aperfeiçoamento da teleducação brasileira. Durante os anos 1980, entretanto, chamam-nos atenção a presença de traços que se reportam, quase que direta ou propriamente, à racionalização: tem coordenado as atividades no âmbito das tecnologias educacionais, concentrando os planos e a administração destas técnicas dispersos até 1982; Todo esse trabalho vem sendo articulado com as secretarias estaduais e municipais de educação, para fins de recepção organizada.

Essa recorrência à racionalidade destaca-se, igualmente, como um dos traços distintivos dos anos 1990. Encontramos seus vestígios, sobretudo, junto à sdr 4, através de enunciados como aceleração do progresso técnico, potencial das novas tecnologias, contribuição metodológica efetiva e busca do equilíbrio entre a educação presencial e a educação à distância. Uma síntese mais expressiva da incidência da racionalização sobre o sujeito do discurso é a seguinte série consecutiva de fragmentos: otimização dos recursos tecnológicos disponíveis; reequipamento das TVEs; ampliação da rede de escolas equipadas; desenvolvimento de estudos e pesquisas na área de teleducação; articulação dos órgãos governamentais e não-governamentais para o desenvolvimento de projetos de teleducação-telemática; intercâmbio do conhecimento acadêmico na área nacional e internacional.

Nesse período, o sujeito do discurso é ainda afetado, particularmente, pela relação custo-benefício, cujos indícios atravessam toda a sdr 3: o investimento que realizamos foi realmente pequeno se comparado aos beneficios que esperávamos alcançar e que alcançamos; contrapor a idéia de que o fato de não termos alcançado no primeiro ano $100 \%$ de audiência e 
100\% de utilização caracterizaria o fracasso e o desperdício de recursos; o que estávamos fazendo, paulatinamente, era ir treinando as pessoas e ir conquistando os professores para o uso da $T V$ Escola, o que haveria de render frutos importantes, como os que estamos colhendo agora. Além disso, marca aquela seqüência o sugestivo enunciado TV Escola, um caso de sucesso que, em parte, é retomado pela sdr 1, mediante a alusão sucesso alcançado pela SEED, evidenciando assim a prevalência do princípio da eficácia, nas últimas duas décadas.

Nos anos 2000, contudo, percebemos a ocorrência significativa de dois outros princípios. A sdr 2 é demarcada por um conjunto de fragmentos que evoca, de modo especial, a inovação e a eficiência, tais como: política que busca a democratização e melhoria da qualidade da educação pública brasileira, por meio da adoção de novos instrumentos e novas tecnologias, até então ainda embrionárias na escola pública do país; A Secretaria de Educação a Distância, em sintonia com estados e municípios, vem, desde então, realizando investimentos significativos em uma infra-estrutura tecnológica que, além de enriquecer o ensino presencial, serve de base para importantes ações de educação a distância..

O enunciado inovações tecnológicas e metodológicas para a melhoria da qualidade da educação no país constitui, por conseguinte, uma síntese de que os princípios da inovação e da eficiência atingem, decisivamente, a sdr 1. Com efeito, representa tal enunciado a evidência de que a recorrência sistemática e permanente por parte do sujeito do discurso à racionalização, ao longo das últimas seis décadas, funda e imprime, de modo quase inexorável, a incidência das características da produção industrial sobre o nosso corpus discursivo. Por sinal, não parece mera coincidência o fato de o T10, antecipando-se aos demais textos, intitular-se 
"A educação e o treinamento por correspondência: histórico e potencialidades".

Apesar de não fazer qualquer menção direta, nem mesmo em suas "Referências Bibliográficas", lembra o T10 a discussão de Max Weber sobre "A 'racionalização' da educação e treinamento", formulada ainda nos anos 1910, por ocasião de suas análises sobre a burocracia. Naquele momento, já acentuava Weber o fato de a qualificação profissional constituir uma condição fundamental à "burocracia moderna". Partindo da Alemanha, "seu berço principal", o treinamento constituía parte imprescindível da reforma do serviço público, desde a China até os Estados Unidos, acompanhando a crescente burocratização do capitalismo, "com sua exigência de técnicos, funcionários, preparados com especialização, etc." (WEBER, 1963b, p.278) Um tipo de "educação" que, pelas suas demandas, dominava e influenciava principalmente as instituições de ensino superior e médio nos países de Primeiro Mundo.

Elemento fundamental à constituição, organização e consolidação do Estado e das grandes empresas capitalistas modernas, "como instrumento de 'socialização' das relações de poder, a burocracia foi e é um instrumento de poder de primeira ordem - para quem controla o aparato burocrático." (WEBER, 1963b, p.264) Neste sentido, a burocracia assume características específicas que a tornam a "forma mais racional" e o "tipo mais puro" de exercício de dominação. Em princípio, rege áreas de jurisdição mediante leis ou normas administrativas e suas atividades regulares são consideradas deveres oficiais, exercidos sob o comando de autoridades e com base na tomada de decisões metódicas. Na esfera privada, esses elementos constituem a administração burocrática e, no serviço público, a autoridade burocrática. 
Caracteriza a burocracia o fato de o princípio de hierarquia implicar um sistema estável de subordinação, cuja supervisão se dá de forma verticalizada. A burocracia constitui um tipo de dominação legítima de caráter racional, assentada na legitimidade da ordem estabelecida, portanto, de forma impessoal, objetiva e legalmente estatuída. O que prevalece é a dominação legal, baseada na idéia de que o direito pode ser estabelecido de modo racional e respeitado por todos os membros de uma organização. Do mesmo modo que o senhor legal típico - o "superior", que pode ser inclusive um chefe de Estado, ao ordenar obedece à ordem impessoal que determina seu mando, os funcionários subordinados, "ao obedecerem ao senhor, não o fazem à pessoa deste mas, sim, àquelas ordens impessoais e que, por isso, só estão obrigados à obediência dentro da competência objetiva, racionalmente limitada, que lhe foi atribuída por essas ordens" (WEBER, 1994, p.142).

Refletindo o próprio fato de a atividade burocrática apresentar-se desvinculada da vida privada, nem a "autoridade institucional" nem seus subordinados apropriam-se do cargo e dos meios de administração e produção. A posse destes está segregada do quadro administrativo, pelo princípio da desvinculação entre o patrimônio da instituição e o patrimônio privado dos seus membros. Mediante o processo de concentração nas mãos dos chefes dos institutos de pesquisa, por exemplo, "a massa de pesquisadores e docentes é separada de seus 'meios de produção', da mesma forma que a empresa capitalista separou os trabalhadores dos seus." (WEBER, 1963b, p.260)

$\mathrm{O}$ direito ao cargo, por sua vez, reduz-se a assegurar o exercício da atividade puramente objetiva, determinada pelas normas referentes ao seu pleno desempenho. 
A investidura em um cargo na burocracia implica assumir uma "profissão", cuja fidelidade ou lealdade não tem finalidades de ordem pessoal, mas apenas e tão somente funcional. Por um lado, põe em prática a possibilidade ótima da especialização administrativa, levando em conta essencialmente critérios "objetivos". Por outro, o cumprimento objetivo das tarefas segue regras calculáveis, nos moldes dos princípios da calculabilidade de resultados que, própria à cultura moderna e à sua base técnico-econômica, é considerada "virtude especial" da atividade burocrática. Sua natureza específica, por sinal, "desenvolve-se mais perfeitamente na medida em que a burocracia é 'desumanizada', na medida em que consegue eliminar dos negócios oficiais o amor, o ódio, e todos os elementos pessoais, irracionais e emocionais que fogem ao cálculo." (WEBER, 1963b, p.251)

Não causa estranheza o fenômeno alcançar o Brasil, de modo especial, a partir da década de 1930, quando começam a ser lançadas as bases de um Estado de Bem Estar Social. Determinadas, em geral, por injunções econômicas, as ações vinculadas à "chamada "política de bem-estar social' operam principalmente no sentido da burocratização, pois essas tarefas são, em parte, atribuídas ao Estado pelos grupos de interesse e, em parte, o Estado as usurpa, devido a sua política de poder ou a motivos ideológicos." (WEBER, 1963b, p.248) Mesmo o Welfare State não representando um conceito tão em voga no Brasil, devido inclusive aos "baixos graus de eficácia e efetividade" das políticas sociais, Draibe (1989) considera que o "Estado social" emerge e se consolida no país, em particular, entre os anos 1930 e 1970. Configurando uma forma de regulação social no âmbito do Estado capitalista, o Welfare State manifesta-se através das transformações 
que incidem sobre a relação Estado, economia e sociedade e fazem emergir sistemas públicos ou estatais de habitação, saúde, educação, entre outros, que afetam o nível de vida da classe trabalhadora, substituindo de alguma forma as políticas de emprego e renda.

Criado, justamente, para consolidar a reforma administrativa deflagrada pelo governo Getúlio Vargas com vistas a "racionalizar o serviço público no país", o DASP nasce em 1938, subordinado à Presidência da República, o que lhe confere papel relevante junto à definição das políticas governamentais. Com o fim do Estado Novo em 1945, o Departamento é profundamente reestruturado. “A partir de então, suas funções assumiram um caráter de assessoria, exceto no tocante à seleção e aperfeiçoamento de pessoal, área em que se manteve como órgão executor." (FUNDAÇÃO, 1997) Transformado em Secretaria de Recursos Humanos do Ministério do Planejamento, Orçamento e Gestão, mesmo assumindo o papel de "modernizar e desburocratizar" a administração federal (BRASIL, 2008e), em 2006 o órgão continuava às voltas com a reestruturação da política de capacitação de pessoal (BRASIL, 2006h).

Essa política, em todo caso, não se resume àquela Secretaria nem ao Ministério do Planejamento, sendo resultado da iniciativa de outras instâncias do Governo Federal, a destacar o Ministério da Educação e a SEED. O Sistema Universidade Aberta do Brasil, além de estar a serviço da democratização da educação superior no país, na medida em que se encarrega da formação inicial e continuada de professores constitui, por conseguinte, uma nova estratégia de racionalização do desempenho dos trabalhadores da rede pública de ensino. Por extensão, atualiza e conduz a estágios avançados o processo de burocratização do 
Estado brasileiro que tende a seguir um movimento mais amplo ${ }^{19}$.

Resulta esse processo, normalmente, em uma forte tendência de subordinação do servidor público ao aparelho burocrático: "o burocrata profissional está preso à sua atividade por toda a sua existência material e ideal. Na grande maioria dos casos, ele é apenas uma engrenagem num mecanismo sempre em movimento, que lhe determina um caminho fixo." (WEBER, 1963b, p.265) Esse mecanismo, inclusive, é quem determina o caminho a ser seguido, ou mais precisamente, o que pode e o que não deve ser dito pelos burocratas responsáveis pela enunciação do discurso oficial, a começar pelos próprios chefes de Estado.

As posições assumidas pelos cinco presidentes que constituem o "discurso presidencial da República Militar Brasileira" nos ajudam a entender como, ao usar a palavra oficial, cada um deles não ocupa um lugar pessoal, mas historicamente afetado por uma FD que o condiciona a exercer a mesma função de sujeito. "O fato de haver uma mudança de locutor nas diferentes séries temporais não determina a concepção de cinco diferentes sujeitos de discurso. Dito de outra forma: esse discurso possui

19 "La administración pública burocrática pretendió erradicar los vicios del patrimonialismo y terminó fusionándose en una rigidez burocrática con diversas manifestaciones 'buropatológicas' en casi todos los países latinoamericanos. Al paradigma burocrático de la administración pública en Latinoamérica se incorporan las teorías organizacionales en los años setenta. Y en los ochenta emerge una gerencia pública que adopta métodos y técnicas de gestión de empresas privadas, con estrategias basadas en la delegación de funciones y en evaluaciones de desempeño, la cual está sustituyendo a la administración burocrática patrimonialista, sobre todo en la provisión de los servicios públicos." (HERNÁNDEZ, 2002, p.27) 
cinco locutores, mas apenas um sujeito do discurso." (INDURSKY, 1997, p.139) Parafraseando a autora, o discurso que ora analisamos possui $n$ locutores, mas apenas e tão somente um sujeito do discurso - o Estado.

Do ponto de vista discursivo, significa considerarmos que o nosso corpus reveste-se, no fundo, de práticas discursivas que transcendem o caráter de "modos de fabricação de discursos" e ganham consistência em instituições, conjuntos técnicos, padrões comportamentais etc., responsáveis pela sua imposição, manutenção e legitimação (FOUCAULT, 1997, p.12). Com efeito, independentemente do tempo, os discursos aí pronunciados acabam revelando não um sujeito lingüístico nem individual, mas um sujeito falante ${ }^{20}$ inscrito numa mesma topografia social ou lugar de enunciação. No caso, o Estado brasileiro, representado através de ministérios (a destacar o MEC), por sua vez, representados por intermédio de comissões, coordenações, departamentos, secretarias (incluindo a SEED), todos constitutivos de uma instância

20 De fato, esclarece Mazière (2007, p.22), o sujeito da AD só é possível ser apreendido "no interior de cada uma das buscas do analista", mesmo porque sua concepção varia substancialmente. "O marxismo, que é uma referência durante os primeiros anos da $\mathrm{AD}$, o sujeita. Foucault o dispersa na formação discursiva. A colaboração entre lingüistas e psicanalistas o resgata do psicologismo. A colaboração com os historiadores introduz um sujeito da história. O peso da interdiscursividade organiza 'a deslocalização tendencial do sujeito enunciador' na materialidade dos enunciados, segundo uma fórmula de Michel Pêcheux. As sofisticações da pragmática o reconfiguram em uma escala de ações e co-ações enunciativas e semânticas na qual ele pode se multiplicar e se diluir. Nos casos mais simples, o sujeito é, no mínimo, dois: falante empírico e enunciador lingüístico." 
que, lembrando Foucault (2004, p.7), tende a autorizar a cada qual falar em seu nome, desde que o discurso esteja inscrito na ordem institucional.

Mais precisamente, trata-se de entendermos que os sujeitos aí envolvidos enunciam através de uma parte do aparelho de Estado que realiza uma série de normas estabelecidas pelas injunções econômicas. "Esse estatuto, literalmente, dá corpo à profissão, e esse corpo investe o discurso que nele se articula - e portanto os indivíduos que o enunciam - de um poder." (LECOURT, 1971, p.60) O que precisamos compreender, esclarece Pêcheux (1968), referido por HENRY (1990, p.26), é que esses sujeitos assumem uma posição definida anteriormente no sistema de produção, que lhes é apagada e cabe a eles próprios reconhecer, mesmo sem ser obrigados formalmente

\section{A ordem e o sujeito do discurso oficial}

Na condição de "sempre-já" sujeito, assim como qualquer outro que assume uma posição condicionada institucionalmente, o sujeito que fala em nome do Estado - tomando emprestada deste a palavra oficial - acaba "sempre-já" esquecendo-se das determinações que o colocaram no lugar que ocupa (PÊCHEUX, 1988, p.170). Esse "esquecimento", porém, não diz respeito a um lapso de memória, mas àquilo que sempre se ignora, ainda que seja extremamente familiar às causas que determinam o discurso (PÊCHEUX; FUCHS, 1990, p.238). “Memória e esquecimento são, assim, indissociáveis na enunciação do político." (COURTINE, 1999, p.22) 
O esquecimento $n^{0} 1^{21}$, afinal de contas, caracteriza-se pela impossibilidade do locutor-sujeito ter acesso ao discurso do Outro, isto é, aos discursos-transversos e pré-construídos que condicionam o seu próprio discurso. $\mathrm{O}$ funcionamento do discurso-transverso, segundo Pêcheux (1988, p.171), tem a ver com a metonímia, correspondendo, a um só tempo, a "'como dissemos' (evocação intradiscursiva); 'como todo mundo sabe' (retorno do Universal no sujeito); 'como todo mundo pode ver' (universalidade implícita de toda situação 'humana')." Emprestado de Henry (1974), a noção de pré-construído por sua vez refere-se a uma construção anterior, exterior, independente e oposta ao que acaba sendo "construído" pelo enunciado, remetendo "aos conteúdos de pensamento do 'sujeito universal'".

Precisamos compreender contudo, esclarece Foucault (2002, p.69), que o pré-conceitual, "em lugar de delinear um horizonte que viria do fundo da história e se manteria através dela, é, pelo contrário, no nível mais 'superficial' (no nível dos discursos), o conjunto das regras que aí se encontram efetivamente aplicadas." Enquanto discurso-transverso, acrescenta Pêcheux (1988, p.167), a interdiscursividade mobiliza os elementos discursivos representados pelo interdiscurso como um pré-construído, através do qual o sujeito se reveste no sujeito falante.

21 É através do esquecimento $\mathrm{n}^{\circ} 2$, por outro lado, que todo sujeito-falante apóia ou encontra sua "liberdade", ao poder selecionar "no interior da formação discursiva que o domina, isto é, no sistema de enunciados, formas e seqüências que nela se encontram em relação de paráfrase - um enunciado, forma ou seqüência, e não um outro, que, no entanto, está no campo daquilo que poderia reformulá-lo na formação discursiva considerada." (PÊCHEUX, 1988, p.173) 
Muito embora, em princípio, constitua o "fio do discurso" do sujeito, o intradiscurso por seu turno acaba caracterizando o efeito do interdiscurso sobre ele próprio, sendo pois determinado por uma exterioridade.

Cabe à forma-sujeito, explica Althusser (1973), retomado por Pêcheux (1988, p.183), "reverter" essa determinação, uma vez que: "Todo indivíduo humano, isto é, social, só pode ser agente de uma prática se se revestir da forma de sujeito. A 'forma-sujeito', de fato, é a forma de existência histórica de qualquer indivíduo, agente das práticas sociais." Constituindo, então, a forma mediante a qual o "sujeito do discurso" assujeita-se a uma FD, a forma-sujeito realiza a incorporação e dissimulação dos elementos do interdiscurso no intradiscurso.

A unidade de um discurso, aliás, atravessa o tempo e transcende os textos e falas individuais, sem que isso suponha permanência mas, ao contrário, transformação dos discursos. Não são os objetos, seu domínio, seu ponto de emergência ou seu modo de caracterização que se mantêm constantes e sim a relação entre suas superfícies. A unidade do discurso reside, pois, não na coerência visível e horizontal dos elementos heterogêneos que a constituem, mas no sistema que possibilita e regulamenta sua formação, mediante os processos de justaposição, coexistência, interação e relacionamento estabelecidos entre esses elementos pela prática discursiva.

A FD, por essa razão, constitui um conjunto complexo de relações que funcionam como regras e caracterizam o discurso pela regularidade ou positividade de uma prática. Prescreve esse sistema de formação aquilo que deve ser correlacionado a essa prática, estabelecendo como a mesma deve se referir a determinado objeto, através de uma determinada enunciação, utilizando um determinado 
conceito e organizando uma determinada estratégia. Essa positividade do discurso exerce o papel, de certa forma, de um a priori histórico, o conjunto das regras que vão caracterizar toda uma prática discursiva e que não se resume ao encadeamento lógico de proposições nem a recorrência de determinados temas: "essa forma de positividade (e as condições de exercício da função enunciativa) define um campo em que, eventualmente, podem ser desenvolvidas identidades formais, continuidades temáticas, translações de conceitos, jogos polêmicos." (FOUCAULT, 2002, p.145-146)

Tratando também do problema da unidade, já esclarecia Althusser (1992, p.70-71) que a dispersão dos aparelhos ideológicos de Estado, em particular, tinha uma explicação. Instituindo-se, principalmente, através do ideológico, o que unifica a diversidade dos AIE “é este funcionamento mesmo, na medida em que a ideologia, na qual funcionam, está de fato sempre unificada, apesar da sua diversidade e contradições, sob a ideologia dominante, que é a ideologia da 'classe dominante'." No fundo, os inúmeros discursos encontram-se circunscritos a um processo mais amplo, através do qual a ideologia interpela os indivíduos em sujeitos, tornando-os, por isso mesmo, "sempre/já sujeitos" que se submetem a um outro sujeito, cuja condição é muito mais abrangente. Conforme explica Pêcheux (1988, p.163), o que essa tese afirma é que o "não sujeito" acaba sendo transformado em "sujeito" por parte da ideologia e, por extensão, em sujeito do discurso pela identificação com a FD que o assujeita.

$\mathrm{Na}$ acepção althusseriana, como toda ideologia pressupõe um centro, ocupado por um Sujeito único e absoluto que interpela, a sua imagem e semelhança, todos os 
indivíduos a sua volta ${ }^{22}$, acontece que o indivíduo é interpelado para livremente realizar sua própria submissão, constituindo-se em sujeitos, portanto, pela sua sujeição. Antes de qualquer coerção, aliás, a maioria dos sujeitos entrega-se à ideologia, às práticas determinadas pelos rituais dos AIE:

Todos os agentes da produção, da exploração e da repressão, sem falar dos "profissionais da ideologia" (Marx) devem de uma forma ou de outra estar "imbuídos" desta ideologia para desempenhar "conscienciosamente" suas tarefas, seja a de explorados (os operários), seja a de exploradores (capitalistas), seja a de auxiliares na exploração (os quadros), seja a de grandes sacerdotes da ideologia dominante (seus "funcionários") etc... (ALTHUSSER, 1992, p.58-59).

22 "Se acrescentarmos, de um lado, que esse sujeito, com um $S$ maiúsculo - sujeito absoluto e universal -, é precisamente o que J. Lacan designa como o Outro (Autre, com A maiúsculo), e, de outro lado, que, sempre de acordo com a formulação de Lacan, 'o inconsciente é o discurso do Outro', podemos discernir de que modo o recalque inconsciente e o assujeitamento ideológico estão materialmente ligados, sem estar confundidos, no interior do que se poderia designar como o processo do Significante na interpelação e na identificação, processo pelo qual se realiza o que chamamos as condições ideológicas da reprodução/transformação das relações de produção." (PÊCHEUX, 1988, p.133-134) 
A consciência individual, para retomar a expressão de Bakhtin (1988, p.36), não é o arquiteto da ideologia, "mas apenas um inquilino do edifício social dos signos ideológicos." Em suma, acentua Pêcheux (1988, p.171), todo sujeito (locutor, sujeito da enunciação, sujeito-falante que remete à articulação ou discurso-transverso) é assujeitado ou interpelado (é determinado a ser o que é, agir como age, falar como fala) pelo sujeito universal da ideologia (Sujeito, o Outro, que se refere ao pré-construído) enquanto singular insubstituível. Como uma faca de dois gumes, resume Maingueneau (1993, p.33), essa instância de subjetividade enunciativa (Sujeito) constitui, legitima e atribui autoridade ao sujeito enquanto sujeito de seu discurso; em contrapartida, o assujeita e o submete as suas regras.

Não tendo o controle sobre o modo como a língua e a história o convocam, resta ao sujeito discursivo funcionar seja através do inconsciente seja mediante o concurso da ideologia que lhe é, antes de tudo, constitutiva (ORLANDI, 2002, p.47). Compondo-se por uma forte articulação entre o inconsciente (relação com o dizer do outro) e o social (relação com a história), o sujeito tem afetado, por um lado, o seu funcionamento psíquico e, por outro, o seu funcionamento histórico-social (INDURSKY, 2000, p.71). Cabe aos sujeitos, concorda Foucault em entrevista a Rouanet e Merquior (1971, p.30), limitar-se a ingressar em um sistema, mantido há tempo, com sistematicidade e existência próprias, independente da existência e consciência de cada indivíduo.

Nesse sentido, tanto as práticas sociais quanto discursivas impõem-se ao sujeito que acaba agindo segundo determinações, mas perdendo a consciência desse processo. Ainda que a prática discursiva não se restrinja 
à atividade de um sujeito e sim a regras que o mesmo necessita obedecer ao participar do discurso (LECOURT, 1971, p.51), a análise dos enunciados e das formações discursivas prescinde de tomar como referência não apenas o sujeito individual, como também uma consciência coletiva, ou mesmo, uma subjetividade soberana ou transcendental. Ela deve se situar, ao contrário, no nível mesmo daquilo que é dito, mas que não é dito de qualquer lugar e sim considerado no jogo de uma exterioridade, em que o sujeito é situado, dependente, jamais titular daquilo que diz, porque o que diz reinscreve efeitos próprios do campo enunciativo.

As positividades, em todo caso, não representam determinações que habitam os indivíduos nem se impõem a eles diretamente do exterior, mas condições de exercício de uma prática que dá lugar, inclusive, a novos enunciados capazes de modificá-la (FOUCAULT, 2002, p.236237). Implica dizer que as relações discursivas nem são próprias ao discurso, como se resultassem dos vínculos entre as frases ou proposições, nem muito menos externas, ou seja, "'circunstâncias' exteriores susceptíveis de coagir o discurso." (LECOURT, 1971, p.51) Nessas condições, por paradoxal que seja, o discurso não pode ser confundido meramente com a reprodução de outro discurso, anterior a ele e determinado pelas "relações de produção e a estrutura sócio-política que delas diretamente deriva" (BAKHTIN, 1988, p.42).

Começa pelo fato de que, apesar de compreender um conjunto de elementos que o antecedem, todo enunciado tem o poder de reorganizá-los e redistribuí-los de acordo com as novas relações possíveis de estabelecer. Soma-se a isso o fato de que, em meio a uma mesma prática discursiva, pode ser possível emitir opiniões, fazer escolhas 
e falar de objetos totalmente opostos. A análise arqueológica, salienta Foucault (2002, p.160), "define tipos e regras de práticas discursivas que atravessam obras individuais, às vezes as comandam inteiramente e as dominam sem que nada lhes escape; mas às vezes, também, só lhes regem uma parte."

Ademais, todo sujeito faz parte de uma comunidade discursiva que produz, faz circular, se reconhece e se reúne em nome de determinados discursos regidos pelo mesmo sistema de formação, mas que não torna essa comunidade simplesmente um agrupamento de porta-vozes. Não sendo possível afirmar, portanto, que todos os indivíduos que aderem a um discurso apresentem grau semelhante de assujeitamento. Mais importante do que associar um conjunto de textos a uma dada formação, adverte Maingueneau (1993, p.105), é "compreender como, em determinado lugar, uma população de autores pôde produzir enunciados similares, partilhar um conhecimento tácito das fronteiras de uma formação discursiva, sabendo o que pode ou não ser dito aí." O que parece mais provável é se tratar da emergência de uma "competência discursiva" que, longe de representar simplesmente a impregnação, imitação ou repetição do discurso, dá-se pelo acesso a um sistema de regras, capaz de produzir e interpretar novos enunciados, ainda que dependentes do "mesmo" discurso.

Retomando o pensamento althusseriano, Pêcheux (1988, p.145) explica que essas contradições se devem, sobremaneira, ao fato de que os AIE não podem ser reduzidos a meros instrumentos da classe dominante, a serviço da reprodução das relações de produção existentes. Ao contrário, eles representam a instância importante de uma luta de classes que projeta a luta de classes em geral. 
"Se os aparelhos ideológicos de Estado têm a função de inculcar a ideologia dominante, isso quer dizer que existe resistência, se há resistência, é que há luta e essa luta é, em definitivo, o eco direto ou indireto, próximo ou, em geral, longínquo, da luta de classes." (ALTHUSSER, 1992, p.112) Contraditória e simultaneamente, os AIE constituem o lugar e as condições ideológicas da reprodução/ manutenção e da transformação/revolução das relações de produção.

Apoiando-se em Henry (1974), Pêcheux (1988, p.216) ressalva que o processo de interpelação ou assujeitamento pressupõe considerar o desdobramento do sujeito do discurso em três diferentes modalidades. A começar por aquela mais evidente que se refere à mera identificação ou superposição entre o sujeito da enunciação e o sujeito universal, caracterizada pelo discurso do "bom sujeito" que, sofrendo cegamente as determinações da FD, reflete de forma "livremente consentida" aquele Sujeito. Segue-se a essa modalidade o discurso do "mau sujeito" que irrompe contra aquilo que o sujeito universal lhe designa a pensar e falar, não mais através de um processo de superposição, mas de separação que implica contestação, contra-identificação e contradiscurso à FD que o interdiscurso teima em impor.

Apesar de apontar para dispositivos de experimentação-transformação da história sob perspectiva marxista-leninista, a terceira modalidade de sujeito do discurso funciona, por seu turno, com base em um processo de desidentificação ou tomada de posição não-subjetiva, mas nunca de dessubjetivação ou desassujeitamento. Em outras palavras, nem ocorre aí anulação da forma-sujeito nem desaparecimento da ideologia; "ao contrário, funciona de certo modo às avessas, isto é, sobre e contra si 
mesma, através do 'desarranjo-rearranjo' do complexo das formações ideológicas (e das formações discursivas que se encontram intricadas nesse complexo)." (PÊCHEUX, 1988, p.217-218) Como a tomada de posição nas diferentes modalidades diz respeito à forma-sujeito dominante, a desidentificação não trata de uma dessubjetivação que torna o sujeito livre, mas de uma identificação a outra forma-sujeito, no caso, secundária ou não-dominante.

Esse entrecruzamento entre formações discursivas e formas-sujeito, aliás, é precedido por uma dupla heterogeneidade. Por um lado, uma FD que comporta mais de um discurso em um só, representando a contradição um princípio constitutivo de toda formação (COURTINE, 1982, p.245). Por outro, uma forma-sujeito que no seu interior já encerra diferença e ambigüidade, dividindo-se entre diferentes posições de sujeito que a FD pressupõe e que representam modalidades particulares da identificação do sujeito da enunciação ao sujeito do saber (COURTINE, 1981). Com efeito, a própria noção de uma FD homogênea “transforma-se para abrigar a diversidade de saberes que essa dispersão de posições-sujeito instaura, tornando-se um domínio de saber heterogêneo e dividido em relação a si mesmo." (INDURSKY, 2000, p.76)

Em última instância, essa heterogeneidade acaba afetando a própria ideologia, uma vez que as várias posições que o sujeito assume estão vinculadas a diferentes formações discursivas e, por extensão, a mais de uma formação ideológica. O que implica que o sujeito, no mais das vezes, apresenta-se ideologicamente heterogêneo e contraditório e que o discurso, com efeito, não se relaciona à ideologia de maneira uniforme. Todavia, ressalvam Orlandi e Guimarães (1988, p.33), a formação dominante que regula as posições do sujeito no discurso "propicia-lhe unidade." 
Até porque, como reconhece Indursky (2000, p.77), continua sendo a forma-sujeito que organiza o saber da FD, determinando assim "o que permanece fora de suas fronteiras"

Convém lembrarmos, ainda assim, que Pêcheux (1990c, p.56-57) nos chama atenção para a importância do acontecimento, ignorado e submetido à FD, uma espécie de "máquina de assujeitamento" capaz de se repetir indefinida e independentemente das circunstâncias discursivas. Todo discurso, entretanto, carrega em si a potencialidade de desestruturação, reestruturação ou agitação, constituindo não apenas efeito, mas também um trabalho consciente ou inconsciente de deslocamento das filiações de identificação. Dessa forma, não há identificação absoluta nem relação sócio-histórica que não possa ser afetada "por uma 'infelicidade' no sentido performativo do termo - isto é, no caso, por um 'erro de pessoa', isto é, sobre o outro, objeto da identificação." (MICHEL, 2006)

A capacidade de reação do sujeito ao discurso dominante é possível, sobretudo, através de uma ação dialética que lhe permita negociar e fazer novas interpretações. Pêcheux (1990c, p.17) concebe o acontecimento discursivo, exatamente, como "o ponto de encontro entre uma atualidade e uma memória", capaz de reorganizar as práticas discursivas. $\mathrm{O}$ acontecimento rompe com os rituais de enunciação, funcionando como o lugar por essência onde o real da língua e o real do discurso se juntam, para produzir novas posições enunciativas que não apenas reconfiguram o próprio discurso, como também "participam do processo de produção do real histórico." (ZOPPIFONTANA, 1997, p.51)

Acontece que não podemos ignorar, igualmente, que os signos (leiamos enunciados e discursos) emergem dos 
processos de interação entre os indivíduos, em especial, entre uma consciência individual e uma outra, ambas por si já repletas de signos. A consciência individual, por assim dizer, apenas e tão somente torna-se consciência quando impregnada de conteúdo ideológico, instituído através de relações que pressupõem que os indivíduos estejam organizados em torno de um grupo ou outra forma de organização social: "só assim um sistema de signos pode constituir-se. A consciência individual não só nada pode explicar, mas, ao contrário, deve ela própria ser explicada a partir do meio ideológico e social." (BAKHTIN, 1988, p.34)

Comentando um dos desafios foucaultianos, Lecourt (1971, p.50) já assinalava que a história dos acontecimentos discursivos não pode deixar de ser analisada "como estruturada por relações materiais que se encarnam em instituições." O discurso em torno da política nacional de educação a distância, embora constituído e reconstituído por uma série de acontecimentos discursivos, dificilmente poderia se encontrar desencarnado, ou mesmo, desidentificado do aparato burocrático-institucional. Emana o discurso oficial não de qualquer instituição, mas de uma estrutura extremamente complexa - o Estado brasileiro que, a despeito de regimes menos ou mais democráticos, tende-lhe imprimir por natureza um caráter autoritário, ainda que venhamos a considerar que incidiria sobre o mesmo uma luta contínua entre a formação dominante e outras não menos importantes formações discursivas e ideológicas.

O que nos permite concluir que o discurso em torno da política nacional de educação a distância, especialmente no período que vai dos anos 1950 até a presente década, encontra-se assujeitado à formação discursiva que refere 
a industrialização do ensino. Por que então, cabe ressaltarmos finalmente, os vestígios ou fragmentos da industrialização do ensino mantêm-se e tendem a transcender esse longo tempo? Porque, mediante o interdiscurso, permitem àquela FD reger ou presidir o discurso enquanto estrutura que permanece ou mantém uma continuidade (memória discursiva), a despeito do funcionamento do intradiscurso. De fato, o acontecimento discursivo mostra-se capaz de reformular a estrutura, só que até onde se faz necessário à FD dominante atualizar-se, isto é, continuar governando o discurso em meio a outras formações discursivas. 